\title{
The effects of genetic differences in an innate immune receptor on immune responses to Haemonchus contortus in sheep
}

\author{
Denzel Deshawn Middleton \\ West Virginia University, demiddleton@mix.wvu.edu
}

Follow this and additional works at: https://researchrepository.wvu.edu/etd

Part of the Animal Sciences Commons, Immunity Commons, and the Parasitology Commons

\footnotetext{
Recommended Citation

Middleton, Denzel Deshawn, "The effects of genetic differences in an innate immune receptor on immune responses to Haemonchus contortus in sheep" (2021). Graduate Theses, Dissertations, and Problem Reports. 8292.

https://researchrepository.wvu.edu/etd/8292

This Dissertation is protected by copyright and/or related rights. It has been brought to you by the The Research Repository @ WVU with permission from the rights-holder(s). You are free to use this Dissertation in any way that is permitted by the copyright and related rights legislation that applies to your use. For other uses you must obtain permission from the rights-holder(s) directly, unless additional rights are indicated by a Creative Commons license in the record and/ or on the work itself. This Dissertation has been accepted for inclusion in WVU Graduate Theses, Dissertations, and Problem Reports collection by an authorized administrator of The Research Repository @ WVU. For more information, please contact researchrepository@mail.wvu.edu.
} 


\section{The effects of genetic differences in an innate immune receptor on immune}

responses to Haemonchus contortus in sheep

\section{Denzel Middleton}

Dissertation submitted to the Davis College of Agriculture, Natural Resources, and Design at West Virginia University in partial fulfillment of the requirements for the degree of

Doctor of Philosophy in Animal and Food Science

Scott Bowdridge, Ph. D., Chair Jianbo Yao, Ph.D. Rosana Schafer, Ph.D. Vagner Benedito, Ph.D. Kimberly Barnes, Ph. D.

Division of Animal and Nutritional Sciences Morgantown, West Virginia 2021

Keywords: Haemonchus contortus, Peripheral blood mononuclear cells, Interleukin- 4, NLRP3

Copyright 2021 Denzel Middleton 


\section{Abstract \\ The effects of genetic differences in an innate immune receptor on immune responses to Haemonchus contortus in sheep Denzel Middleton}

Little is known about differences observed in early immunological signaling events that result in cellular infiltration and Th2 cytokine production that mediate parasite expulsion. Parasite resistant St. Croix (STC) sheep have been used as model for full host protective immunity as they present the ability to respond to larval stages of $H$. contortus. RNA sequencing analysis of peripheral blood mononuclear cells (PBMC) stimulated with $H$. contortus larval antigen (HcLA) revealed significant upregulation in NLRP3 and its pathway component TLR4. Predicted protein structural software identified distinct differences in NLRP3 protein structure in STC and parasite susceptible Suffolk (SUF) sheep. NLRP3 has been widely studied in a classic model of inflammatory infection, but little is known about its role in helminth infections. The inhibition of NLRP3 in a classic model of infection reduced STC PBMC responses on both the transcript and protein level but had no effect on the transcript level for SUF PBMC only the protein level. In an HcLA infection model PBMC from SUF with the inhibition of NLRP3 resulted in the upregulation of TLR4, TLR2, and IL-10. We hypothesize NLRP3 loss of function to have a significant impact on components of TLR4 signaling and inflammatory immune activation to pathogenic challenge. The inhibition of a dysfunctional NLRP3 receptor in SUF sheep maybe a potential target for chemotherapeutics to achieve full host protective immunity. 


\section{Acknowledgements}

First and foremost, I would like to thank my advisor Dr. Scott Bowdridge for seeing something in me and giving me the opportunity to challenge myself in a new area. My very first day on the job was my very first time ever handling sheep and his patience and coaching helped me to be the sheep handler I am today. Dr. Bowdridge has challenged me to think big picture, think about the impact of my work, and to be comfortable juggling multiple hats. I have learned so much about workmanship and my abilities to push myself and strive for success throughout my journey at WVU and I owe it all to my advisor who has pushed me to be comfortable stepping out of my comfort zone and who has given me this great opportunity. I have learned so much from Dr. Bowdridge both in the lab and in life that has made me both a better scientist and an overall more productive adult. I am truly grateful for this opportunity.

To my lab mates Brynnan Russ, Andrew Weaver, Camren Maierle, Curtis Patton, Roger Rohrbaugh, and Kelsey Bentley thank you for keeping me sane throughout extensive farm days. You guys were always there to help when needed, this process is anything but easy, but you guys make the process a positive experience.

Lastly, I would like to express how grateful I am for the constant love and support that I receive from my friends and family. My parents Raquel and Lloyd and stepdad Boris have stuck by me throughout every decision made along this journey without question. My siblings and friends have lent a listening ear a time or dozen over the course of this journey, even without knowing what I was talking about, they would just listen and say everything will be ok. Thank you all for your love and support, I love you all. 


\section{Common Abbreviations:}

ATP $=$ Adenosine Triphosphate

NLRP3 = NLR family pyrin domain containing 3

$\mathrm{CM}=$ Complete media

TLR $=$ Toll like receptor

PBMC $=$ Peripheral blood mononuclear cell

$\mathrm{STC}=$ St. Croix

SUF $=$ Suffolk

Th2 = T-helper type 2

HcLA = Haemonchus contortus larval antigen

HcWA= Haemonchus contortus adult worm antigen

LPS $=$ Lipopolysaccharide

IL = interleukin

ELISA = enzyme linked immunosorbent assay

IFN $\gamma=$ interferon gamma

$\mathrm{Hc}=$ Haemonchus contortus

GCN = Gulf coast native

T. muris $=$ Trichuris muris

N. brasiliensis $=$ Nippostrongylus brasiliensis

H. Polygyrus = Heligmosomoides polygyrus

MCC950 $=$ NLRP3 inhibitor

1400W $=(\mathrm{N}-(3-($ aminomethyl $)$ benzyl $)$ acetamidine $)$ - iNOS inhibitor

$\mathrm{SEM}=$ Standard error of the mean 


\section{Table of contents}

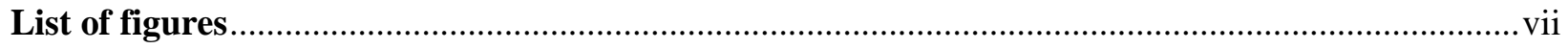

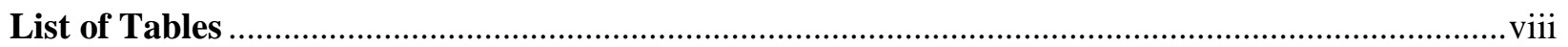

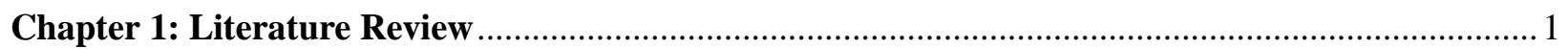

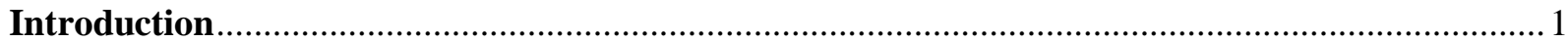

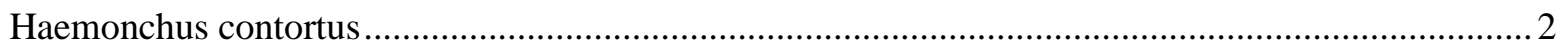

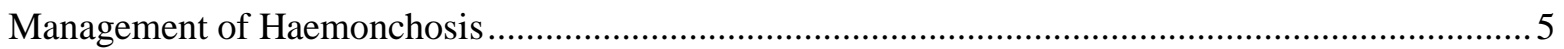

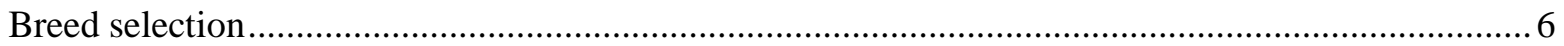

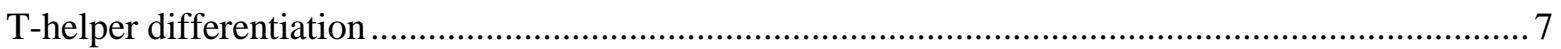

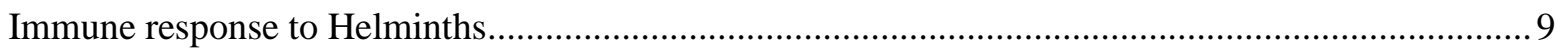

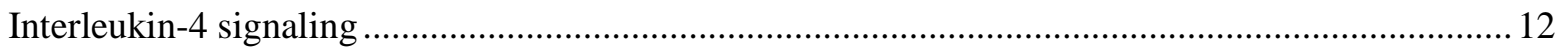

Nod-like receptor family, pyrin domain-containing 3 (NLRP3)................................................ 15

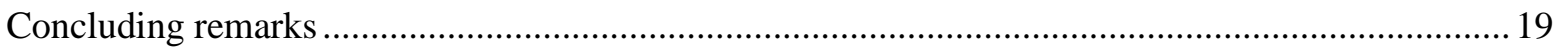

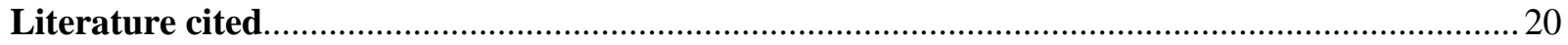

Chapter 2: The role of NLRP3 in explaining sheep breed differences in response to LPS stimulation

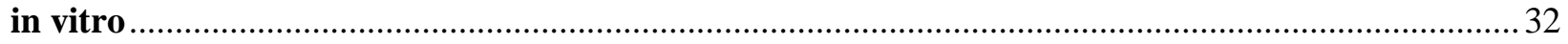

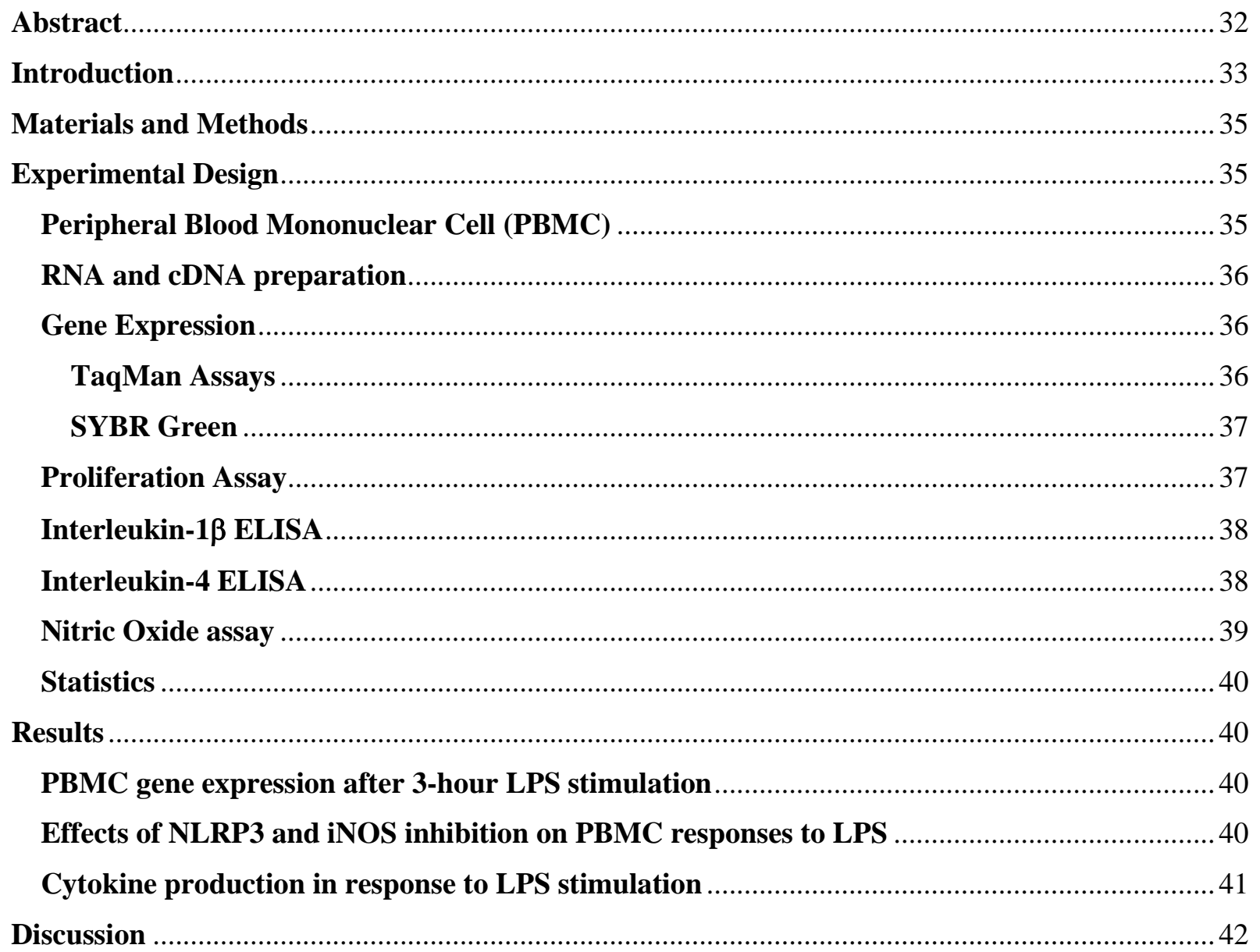


Chapter 3: The role of NLRP3 signaling in host protective immune response to Haemonchus contortus infection .56

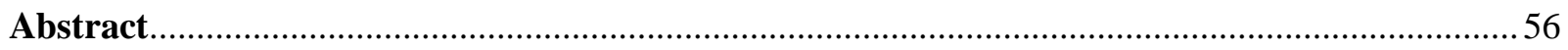

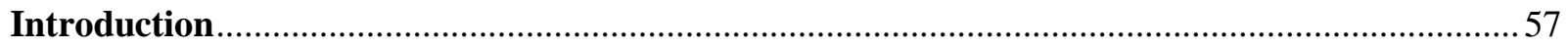

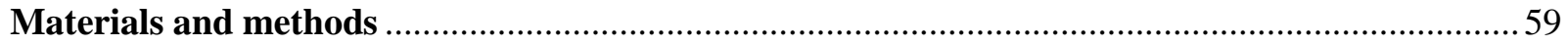

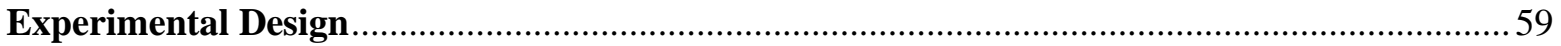

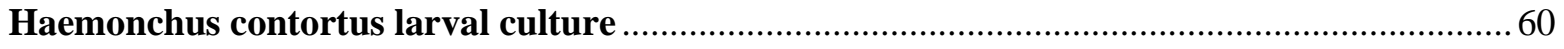

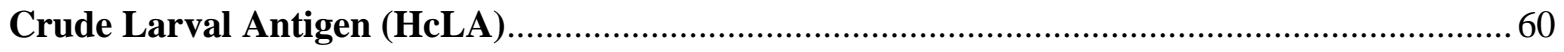

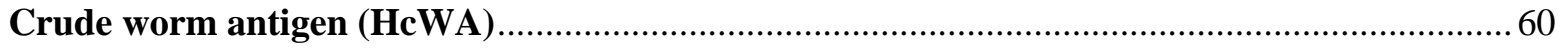

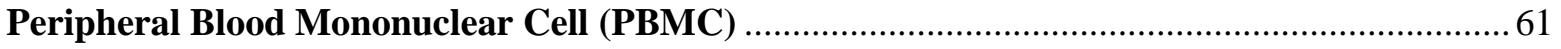

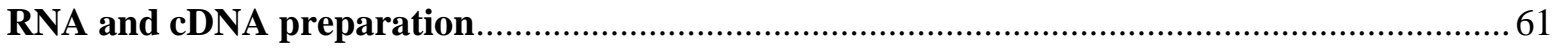

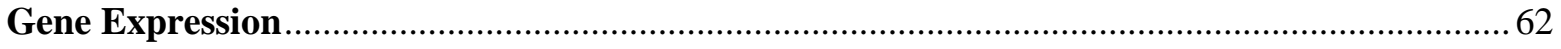

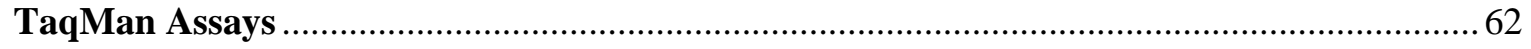

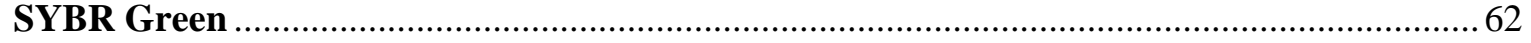

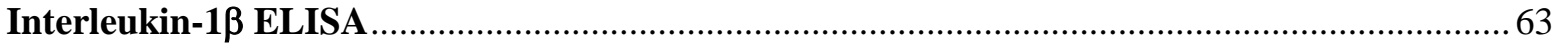

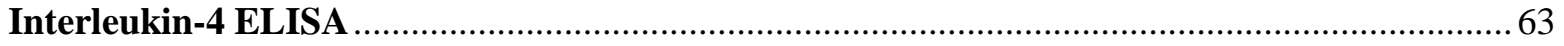

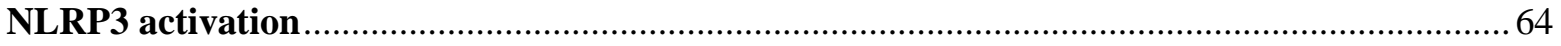

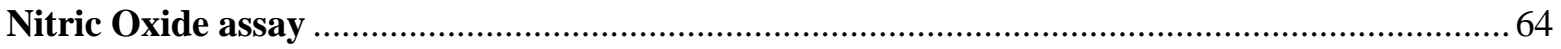

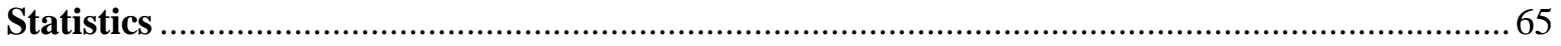

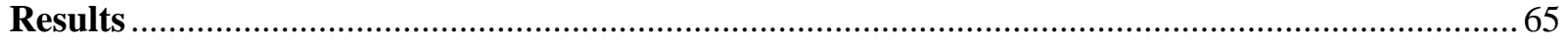

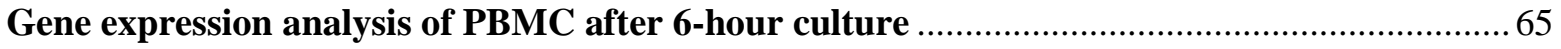

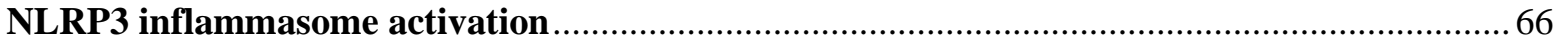

Protein concentration in cell culture supernatant ................................................................... 66

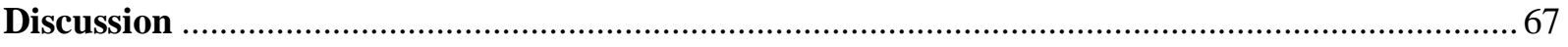

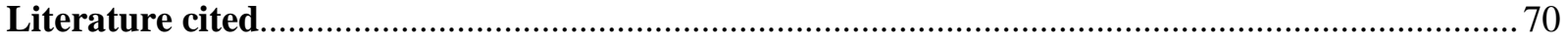

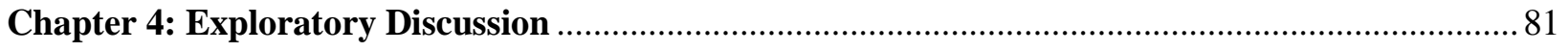

Figure 4.1: Model for STC PBMC responses to LPS stimulation ................................................ 81

Figure 4.2: Model for SUF PBMC responses to LPS stimulation ............................................... 82

Figure 4.3: Model for NLRP3 in Haemonchus contortus infection in sheep ............................... 83 


\section{List of figures}

Chapter 2

Figure 2.1: Gene expression analysis of PBMC after 3 hours LPS culture

Figure 2.2: Inhibition of NLRP3 inflammasome formation in PBMC stimulated with LPS

Figure 2.3: iNOS inhibition in PBMC

Figure 2.4: Pharmacological inhibition of NLRP3 and iNOS

Figure 2.5: Quantification of IL-4 protein in cell culture supernatant after LPS stimulation

Figure 2.6: Nitrite concentrations in cell culture supernatant after stimulation with LPS

Figure 2.7: PBMC proliferation assay after LPS administration

Chapter 3

Figure 3.1: Gene expression analysis of PBMC after 6-hour culture with HcLA

Figure 3.2: NLRP3 inflammasome activation

Figure 3.3: Inhibition of NLRP3 inflammasome activation in PBMC

Figure 3.4: Measure of IL-4 protein in cellular supernatant

Figure 3.5: Measure of IL-1 $\beta$ protein in cellular supernatant

Figure 3.6: Measure of nitrite in cellular supernatant

Chapter 4

Figure 4.1: Model for STC PBMC responses to LPS stimulation

Figure 4.2: Model for SUF PBMC responses to LPS stimulation

Figure 4.3: Model for NLRP3 in Haemonchus contortus infection in sheep 


\section{List of Tables}

Table 2.1. qPCR primers for SYBR Green chemistry

Table 3.1. qPCR primers for SYBR Green chemistry 


\section{Chapter 1: Literature Review Introduction}

Sustainability of global small ruminant production, that provides a single source of meat, milk and fiber, hinges on the ability to control gastrointestinal parasitism. Traditional control methods rely heavily on chemotherapeutics, yet overuse has led to populations of parasites resistant to all classes of drug treatment. Drug-resistant worms are a global problem and therefore require a global solution. Our previous work has demonstrated robust parasite-resistance in the St. Croix breed of sheep infected with Haemonchus contortus (Hc) and has identified specific immunological mechanisms underpinning this resistant phenotype. To further explore these differences, an in vitro model system has been developed using peripheral blood mononuclear cells, allowing breed comparisons, at a cellular level, to determine variation in response to stimulation with Hc antigen.

The classic immune response to helminth parasites is a Th2 response and this has been studied mainly using murine models of infection. This same response is found in sheep and results in reduction of adult worm establishment and fecundity. Innate immune cell influx (eosinophils, mast cells, globule leukocytes), cytokine production (IL-4, IL-5, IL-13), and increased parasitespecific antibody (immunoglobulin A ( $\operatorname{Ig} \mathrm{A}), \operatorname{IgE})$ production are all implicated in parasite expulsion (Balic et al., 2000, Lacroux et al., 2006). The abomasal environment during a Th2 response is characterized by increased luminal flow and intestinal muscle contractility, responses driven by IL-4 and IL-13 cytokines (Harris et al., 2011). Interleukins 4 and 13 are hallmark cytokines of Th2-associated disease, both signal through Interleukin-4 receptor (IL-4R), exhibiting a vast array of functions in regulating inflammation (Lademarco et al., 1995; Wynn et al., 2003). Previous studies have implicated elevated expression of Toll like receptors (TLR), NLR family 
pyrin domain containing 3 (NLRP3), and tissue remodeling associated genes in PBMC isolated from resistant St. Croix (STC) sheep as compared to susceptible Suffolk (SUF) counterpart (Jacobs et al., 2019). In the context of parasitic infections, parasites such as Schistosoma mansoni and Heligmosomoides polygyrus secrete proteins that directly activate the NLRP3 inflammasome in vitro and promote the production of IL-1 $\beta$ (Ritter et al., 2010; Zaiss et al., 2013). Genetic deficiency in NLRP3 results in suppression of Th1, Th2, and Th17 immune responses and reduced liver pathologies in a Schistosoma mansoni infection model (Ritter et al., 2010).

Thus, the focus of these experiments conducted in this dissertation was to investigate the relationship between NLRP3 and IL-4 in the context of Haemonchus contortus nematode infection in sheep and to better understand immune differences that may be exploited to develop novel treatments that can be used to better manage parasitism in small ruminants. These findings will improve sheep management globally, supplying producers with proper therapeutics to combat parasitic infection.

$\underline{\text { Haemonchus contortus }}$

Haemonchus contortus is a hematophagous enteric parasite commonly known as the "barber-pole worm". Haemonchus belongs to the order Strongylida and a member of the Trichostrongyloidea family (Roeber et al., 2013). The barber-pole appearance is common for adult females as their white ovaries are wrapped around blood-filled intestines. Males are between 10$20 \mathrm{~mm}$ in length while females are about $18-30 \mathrm{~mm}$ in length (Roeber et al., 2013). Female adult worms can produce anywhere from 5,000 to 10,000 eggs per day within the abomasum of its host. The presence of a small, specialized buccal lancet on the end of fourth stage larvae (L4) and adult mouth parts, allow piercing of the abomasal mucosal lining and feeding on host blood (L. S. Roberts et al., 2009). Haemonchosis is most prevalent in tropical and sub-tropical regions under warm and wet conditions. 
Haemonchus contortus (H. contortus) has a direct life cycle, which takes 14-21 days from egg to mature adult (Machen, 1914). Throughout their life cycle H. contortus larvae undergo five stages of development separated by structural changes. The first two stages and part of the third stage are non-parasitic and occur outside of the host, while maturation of L4 and fifth stage larvae (L5) occur within the abomasum and are parasitic in nature. Outside the host, larvae are considered free living. Each larval stage can be split into substages with the first being a more active stage and the second being a lethargic stage (Veglia, 1916). The lethargic stage is the period of rest before initiating molting into the next stage of development (Veglia, 1916).

Adult male and female $H$. contortus reside in the abomasum of small ruminants, where sexual reproduction occurs. Following reproduction, gravid females lay eggs, which are passed through feces into the environment. Larval development is highly dependent on environmental temperature and moisture level. Optimal temperatures for egg hatch and larval development are between $20^{\circ}$ and $35^{\circ} \mathrm{C}$. Egg hatch occurs under warm and moist conditions, if in soil, eggs hatch and the first larval stage (L1) is released into the environment (O'Connor et al., 2006). Free-living L1 are active in soil, engaging in sinusoidal movement and equipped with a complete digestive tract from mouth to anus. Bacteria and waste found in feces serve as food for L1. As larvae continue to develop, the outer cuticle begins to shed within two days of hatching, and the larvae will molt into second stage larvae (L2). Increased motility and feed consumption can be used as an indicator of L2 maturation (Veglia, 1916).

Under desirable warm and moist environmental conditions larvae will continue to develop and molt into third stage larvae (L3), the infective stage. Movement and travel occur most at dawn, as larvae travel up grass blades in dew droplets due to natural cohesion, where ingestion may occur by a grazing host. During the day larvae can be found protected from sunlight, closer to the ground 
and in feces. Infective L3 have been found to be most active between temperatures of $42^{\circ}-50^{\circ} \mathrm{C}$ (Veglia, 1916). Structurally, L3 are encased in a cuticle which protects them from the environment, desiccation, and covers their mouth, preventing the larvae from feeding. At this point larval metabolism is dependent on the consumption from both the L1 and L2 stages (Veglia, 1916).

Infective L3 are ingested by a grazing sheep, and travel through the host's digestive tract and begin exsheathment and development to L4 within the abomasum 48 hours after ingestion. In the abomasum, L4 pierce the mucosal lining and feed off pools of blood (L. S. Roberts et al., 2009). L4 stage within the abomasum can undergo an arrested stage in times of unfavorable external environmental conditions for parasite development called hypobiosis (Gibbs, 1982). Under favorable conditions, three days after ingestion, larvae molt from L4 and become mature adult worms. Sexually dimorphic adults will reproduce, females will shed eggs in feces, and adults continue to take blood meals from its host, perpetuating the life cycle (Veglia, 1916).

Lambs younger than 6 months of age and immunocompromised individuals are most affected, with peak infection typically occurring throughout spring and summer months (Dineen and Wagland, 1966). While in the host, during winter months, larvae deposited during summer months go into hypobiosis until the external environment is suitable for maturation (Gibbs, 1982). There is a positive correlation between the number of adult $H$. contortus worms found in the abomasum of infected sheep, and the number of eggs that are shed in the feces (J. L. Roberts \& Swan, 1981). Producers utilize fecal egg counts (FEC) as an approximation of parasite burden or as a useful indicator of anthelmintic treatment effectiveness expressed as the number of eggs per gram of feces (EPG). Packed cell volume (PCV), a marker of anemia, is also utilized as a measure of infection (Dineen and Wagland, 1966). The prevalence of infection with $H$. contortus follows a trend of the availability of L3 on pasture (J. L. Roberts \& Swan, 1981). 
Pathologies associated with Haemonchosis range from sub-clinical to lethal pathologies and are a result of blood feeding by L4 and adult stages (J. L. Roberts \& Swan, 1981). Symptoms of acute disease depend on infection intensity and include weakness, anemia, reduced wool production and muscle mass, or even sudden death (Veglia, 1916). Chronic disease pathologies of H. contortus infection include decreased feed intake, weight loss, anemia, hypoproteinemia, and death (Besier et al., 2016). Parasitic infections can also have indirect effects on metabolism, forcing its host to utilize protein stores during an immune response and lead to decreased feed intake and increased susceptibility to other pathogens (Besier et al., 2016).

\section{Management of Haemonchosis}

Initial reports of $H$. contortus anthelmintic resistance in sheep occurred in the late 1950's to the drug phenothiazine (Drudge et al., 1957). Field populations of $H$. contortus have shown resistance to all major anthelmintic drug classes including benzimidazoles, imidazothiazoles, and macrocyclic lactones. Resistance appeared less than 10 years after the introduction of a new drug class (Kotze and Prichard, 2016). Thiabendazole was introduced in 1961 as the first to combine broad-spectrum nematocide with low toxicity. Within a few years, resistance was reported in sheep operations due to anthelmintic overuse. Similar trends in resistance patterns have been reported for benzimidazoles and imidazothiazole drug classes within a few years of efficacy (Conway et al., 1964; Waller et al., 1986). Resistance to the most recent drug treatment available in Australia, amino-acetonitrile derivatives (AADs), has recently been reported in H. contortus (Mederos et al., 2014; Van den Brom et al., 2015). As the level of resistance continues to increase, the efficacy for drugs will continue to decline, leaving producers with no choice but to utilize alternative methods to manage parasitism. 


\section{Breed selection}

Incorporating parasite-resistant breeds of sheep into breeding programs has been an alternate strategy of interest for controlling $H$. contortus infection. Resistant sheep do not completely eradicate the infection, but they have a lower parasitic load, as measured by fewer eggs in their feces, and a decrease in abomasal worm burden at necropsy as compared to susceptible sheep (Gill, 1991). Due to natural selection, Caribbean native St. Croix (STC) sheep are able to thrive in temperate, high parasitic environments (Shakya et al., 2009). St. Croix sheep are of Caribbean origin, which is an environment conducive to year-round exposure to $H$. contortus. St. Croix have developed a robust immune response early to larval stages of $H$. contortus preventing establishment of adults (Alba-Hurtado and Munoz-Guzman, 2013). However, parasite resistant STC sheep lack economically desired traits, reducing their usefulness in a crossbreeding program (Gamble and Zajac, 1992). Suffolk (SUF) sheep, originating in cold and wet environments of England, are a common economically desirable breed that are highly susceptible to $H$. contortus (Miller et al., 1998). Inability of SUF to respond to larvae permits the establishment of adults within the abomasum, leading to adverse symptoms such as anemia, edema, hypoproteinemia, weight loss, and in severe cases, death ${ }^{19}$. Symptoms are most prevalent in young animals, while repeated exposure to infection aids in resistance development in adult animals (Barger et al., 1985).

A resistant phenotype is a host's ability to reduce the establishment of the parasite and modify its egg production. Resistance to H. contortus is immunologically mediated. Treatment of Gulf Coast Native resistant sheep with dexamethasone for immune suppression led to a reduction in resistance phenotype, characterized by higher eggs per gram and increased total worm burden within the abomasum of resistant host (Peña et al., 2004). In comparing uninfected susceptible and resistant Corriedale sheep, resistant sheep were presented with significantly greater Haemonchus contortus adult-specific IgG titers in plasma as compared to uninfected susceptible sheep. This 
same trend was observed when measuring Haemonchus contortus $\mathrm{L} 3$-specific IgG titers in plasma of resistant and susceptible Corriedale sheep. This correlates to a form of natural immunity in resistant breeds to life stages of Haemonchus (Escribano et al., 2019). Pasture infected Gulf coast native (GCN) lambs have demonstrated the ability to respond to $H$. contortus larval stages early in infection as shown by eosinophilia, mast cell hyperplasia, and globule leukocytosis within the abomasal mucosa (Shakya et al., 2009). Studies have observed delayed responses of immune components vital for T-helper type 2 (Th2) initiation in SUF sheep. For instance, gene expression analysis of wound healing and tissue repair associated genes were upregulated in abomasa tissue of STC lambs and downregulated in SUF lambs following $H$. contortus infection (MacKinnon et al., 2015). These data suggest a form of natural immunity for resistant sheep and highlights the differences in the timing of responses between resistant and susceptible sheep. Early activation of Th2 responses is vital to achieve a resistant host phenotype.

T-helper differentiation

T-helper $\left(\mathrm{T}_{\mathrm{H}}\right)$ cells and their cytokines produced play an integral role in the responses of $\mathrm{B}$ cells, natural killer (NK) cells, and other T cells. Cytokine secretion profiles of $\mathrm{T}_{\mathrm{H}}$ cells have the capacity to induce dramatic pleiotropic effects on nonlymphoid cells. It has been shown that in response to infectious agents, commensal microorganisms, or self-antigens naïve $\mathrm{CD} 4^{+} \mathrm{T}$ cells can differentiate into different subsets $\left(T_{H} 1, T_{H} 2, T_{H} 9 T_{H} 17\right.$, and inducible regulatory) based on their lymphokine secretion patterns (Zhu et al., 2010). The cytokine environment in which the naïve $\mathrm{T}$ cell resides is a vital component of determining the cells differentiation pathway (Romagnani et al., 2000; Saravia et al., 2019). T-helper type 2 cells are essential for host immunity to extracellular parasites, asthma, and allergic inflammatory disorders, while Th1 cells are necessary for immunity to intracellular pathogens (viruses, bacteria, fungi) (Kanhere et al., 2012). Failure to mount an appropriate response to foreign pathogens increases the severity of disease. 
$\mathrm{T}$ cell subsets can be distinguished by cytokine production, expression patterns, and cell surface molecules. Signature cytokines of Th1 cells are IFN $\gamma$, IL-12, and TNFa. On the contrary Th2 cells fail to produce IFN $\gamma$, their signature cytokines include IL-4, IL-5, and IL-13 (Killar et al., 1987). Interleukin-12 and IL-4 are the most potent factors that influence Th1 and Th2 differentiation. Interleukin-12 induces Stat-4 phosphorylation in developing and differentiated Th1 cells but not in Th2 cells (Kaplan et al., 1996) and IL-4 activates Stat-6 phosphorylation in Th2 cells. The activation of Stat-4 and Stat-6 is crucial in T cell subset development, mice deficient in these two Stat proteins were unable to generate Th1 and Th2 responses. Stat-4 deficient mice led to impaired development of Th1 cells in response to treatment with IL-12 or Listeria monocytogenes (Kaplan et al., 1996). An in vitro model investigating the effect of IL-4 on naïve precursor $\mathrm{CD}^{+}$cells revealed that the addition of IL-4 to culture altered the pathway of differentiation as compared to cells not exposed to IL-4. Interleukin-4 exposure resulted in the development of effector cells secreting IL-4, IL-5, IL-3, and GM-CSF. The absence of IL-4 or little endogenous IL-4 present in culture resulted in effector cells developed with low secretion levels of IL-4, IL-5, IL-13, and IFN $\gamma$. Addition of anti-IL-4, enriched development of IFN $\gamma$ and IL2 producing cells (Swain et al., 1990).

$\mathrm{T}$ cells purified from mice that expressed transgenes, encoding a $\mathrm{T}$ cell receptor specific for pigeon cytochrome $\mathrm{C}$ peptide 88-104, were used to assess factors that determined $\mathrm{T}$ cell differentiation pathways, specifically Th1 and Th2. Under normal conditions these transgenic cells produced limited amounts of IL-4 or IFN ${ }_{\gamma}$ after culture with peptide 88-104 and antigen presenting cells (APC) alone. Priming cells for four days in the presence of peptide 88-104, APC, and 1,000 $\mu \mathrm{l} / \mathrm{ml}$ of IL-4 with administration of a rechallenge of IL-4 resulted in the cells ability to produce ample amounts of IL-4 and inhibit the production of IFN $\mathrm{N}_{\gamma}$ Transgenic cells primed in the absence 
of IL-4 produced significant amounts of IFN $\gamma$ and reduced the secretion of IL-4, the inhibitory capacity of IL-4 on IFN $\gamma$ was independent of IL-10 (Seder et al., 1992). Thus, early cytokine presence affects differentiation of naïve lymphocytes resulting in appropriate responses necessary for pathogen clearance.

Immune response to Helminths

According to the World Health Organization (WHO), more than two billion humans are infected with parasitic helminths. Although infections by these pathogens are not always fatal, they have been associated with high rates of morbidity, anemia, malnourishment, and coinfection (WHO, 1999). Helminth diseases are still widespread affecting all mammals and drug treatments have declined in effectiveness due to overuse. Mechanisms of resistance to helminths are not yet fully understood. Thus far there have been discovery of innate and adaptive responses necessary for proper eradication of helminths from their host (Patel et al., 2009). The host protective immune response has been referred to as Th2 immune activation. Host Th2 activation to helminth larval stages reduce adult establishment and fecundity, further reducing symptoms and pathologies associated with helminth disease (Owyang et al., 2006).

T-helper type 2 responses are characterized by an increase in interleukin-4 (IL-4), IL-13, IL-5, IL-21, and IL-25 cytokines, which promote the recruitment, activation, and expansion of cluster of differentiation $4^{+}\left(\mathrm{CD}^{+}\right) \mathrm{Th} 2$ cells, plasma secreting $\operatorname{IgE}$ and $\operatorname{Ig} \mathrm{A}$ cells, eosinophils, mast cells, and basophils (Balic et al., 2000; Lacroux et al., 2006). The life cycle of Nippostrongylus brasiliensis ( $N$. brasiliensis) in rodents follow a pattern of hepato-tracheal migration and serves as a useful model to study host immunopathology arising from nematode infections (Ehigiator et al., 2000). N. brasiliensis immune mechanism is $\mathrm{CD}^{+} \mathrm{T}$ cell-mediated with dependence on IL-4 production to induce B cell class switching and promote increased IgE in host serum within 7-13 days post infection (DPI) (LeGros et al., 1996). Basophils have been 
implicated to be the effector source of IL-4 production during primary $N$. brasiliensis infection independent of both IL-4/STAT6 signaling. During challenge infection, basophils are rapidly recruited however, $\mathrm{CD} 4^{+} \mathrm{T}$ cells serve as the dominant source of IL-4. Basophils, during $N$. brasiliensis infection, are not necessary for Th2 differentiation, as the number of B cells present in the local lymph nodes were not affected when basophils were depleted. However, in the absence of basophils, effector cell recruitment to the periphery was diminished (Van Panhuys et al., 2011). Studies have shown an increase in IL-5 in blood and lung tissue within 7-9 DPI, promoting eosinophilia (Coffman et al., 1989; Kopf et al., 1993). The final phase of infection is characterized by an increase in IL-4, IL-13, and IL-9 dependent mastocytosis followed by an influx of IL-13 and IL-4 within the mucosal wall of the gut, aiding in parasite expulsion from the small intestine (Madden et al., 1991; Townsend et al., 2000; Urban et al., 1998).

More relevant to studies in this dissertation are murine parasitic infections with Heligmosomoides polygyrus (H. polygyrus), its mode of infection resembles Haemonchus contortus. Resistance to $H$. polygyrus infection is immune mediated and $\mathrm{CD} 4^{+} \mathrm{T}$ cell dependent (Urban et al., 1991a). (Urban et al., 1991a). The level of infection within a rodent host has shown to be limited by the expression of IL-4 at the site of infection (Urban et al., 1991b), which is dependent on IL-4R $\alpha$ receptor activation of STAT6 (Finkelman et al., 1997). A host resistance phenotype is composed of both a primary and secondary response. Primary responses include modest changes in intestinal epithelial cell function, including permeability and early innate cell influx associated with IL-4 production (Shea-Donohoue et al., 2001). Memory responses have been shown to occur within 4 days post challenge infection, characterized by granulomatous formation consisting of neutrophil infiltration surrounding invading larvae, followed by alternatively activated macrophages (AAM $\phi$ ) surrounding larval and neutrophils clumps (Anthony et al., 2006; 
Morimoto et al., 2004; Kreider et al., 2007). Granuloma formation is indicative of acute inflammatory responses to invading pathogens necessary for full host protective immunity (Gause et al., 2003). At the border of the granuloma there is an accumulation of $\mathrm{CD} 4^{+} \mathrm{T}$ cells, dendritic cells, and eosinophils (Anthony et al., 2006). The memory response in $H$. polygyrus infection is heightened by the dichotomy of an acute inflammatory response and a memory $\mathrm{Th} 2$ response leading to immune cell influx to the site of infection, resulting in parasite damage (Anthony et al., 2006).

Th2 immune activation, in response to $H$. contortus larval stages, reduce adult establishment and fecundity. Innate immune cell influx (eosinophils, mast cells, neutrophils, globule leukocytes), cytokine production (IL-4, IL-5, IL-13), and increased parasite-specific antibody (IgA, IgE) production are all implicated in parasite expulsion (Balic et al., 2000, Lacroux et al., 2006). The gastrointestinal environment during a Th2 response is characterized by increased luminal flow coupled with intestinal muscle contractility, and these responses are driven by IL-4 and IL-13 cytokine production (Harris et al., 2011).

In the context of $H$. contortus infection in sheep, research has demonstrated a correlation between elevated IL-4 and IL-13 expression during early infection and prevention of parasite establishment. Initial IL-4 expression was detected in STC abomasal tissue by day 3 and in SUF sheep at day 10-post infection. These data indicate a delay in IL-4 expression in susceptible sheep (Jacobs et al., 2016). IL-13 expression at 3 days post infection (DPI) was significantly increased in both STC abomasum and lymph node tissue but was markedly reduced in susceptible sheep (MacKinnon et al., 2015). Delayed SUF IL-4 expression and reduced IL-13 expression to Haemonchus larval stages in susceptible hosts, permit the establishment of adults. Bowdridge et al., (2015) identified cellular infiltrate of abomasal tissue during the first 7 days of $H$. contortus 
infection and found a significant increase of neutrophils in STC abomasum when compared to SUF sheep at 3 DPI.

An in vitro model of $H$. contortus larval antigen stimulation of ovine neutrophils revealed an ability to produce IL-4 as early as 30 minutes after antigen stimulation with no breed differences observed. Neutrophils preferentially produced significant amounts of IL-4 after stimulation with larval but not adult $H$. contortus antigen. In culturing larval antigen primed neutrophils with naïve peripheral blood mononuclear cells (PBMC), primed neutrophils were able to induce the production of IL-4 in naïve cell populations (Middleton et al., 2020). From these data, it is reasonable to conclude early neutrophil infiltration, IL-4 production, and increased early IL-4 and IL-13 expression in abomasal tissue of STC lambs drive activation of early Th2 responses. Haemonchus contortus infected STC PBMC (composed of monocytes and lymphocytes) cultured with larvae led to a reduction in larval motility (Holt et al., 2015). Quantifying larval death after culture with PBMC by ATP quantification further found a greater reduction in larval ATP when cultured with STC PBMC as compared to culture with SUF PBMC (Shepherd et al., 2017).

Taken together, these studies demonstrate the significance of early IL-4/IL-13 signaling in promoting parasite expulsion. Interleukin-4 acting on Th2 cells causes the subsequent production of IL-4 creating a positive feedback loop and promoting the differentiation of B cells to plasma cells, necessary for both IgE and IgG production (Armitage et al., 1992). Differences between resistant and susceptible sheep have been documented with emphasis on a delay in response to larval stages observed by susceptible sheep.

Interleukin-4 signaling

Interleukin-4 is a multifunctional cytokine that signals using the IL-4R complex and plays a critical role in the regulation of immune responses. This molecule exerts various biological effects by regulating proliferation and differentiation of a variety of lymphoid and myeloid derived 
cells (Paul et al., 1991). T helper type 2 activation during helminth infection has shown dependence on IL-4 and IL-13 signaling, both molecules signal through IL-4R $\alpha$. Gut nematode infections have deemed IL-4R $\alpha$ signaling to be critical in the initiation and development of host protective Th2 responses during both primary and secondary infections (McKenzie et al., 1999; Anthony et al., 2006). Recent studies have investigated the importance of IL-4R $\alpha$ during $N$. brasiliensis infection, with use of a Cre-Lox recombination to disrupt IL-4R $\alpha$ signaling (Horsnell et al., 2010). Impairment of IL-4R $\alpha$ signaling during primary and secondary infection led to disruption in Th2 responses and affected the host's ability to expel worms. To observe the efficacy of long-lasting IL-4R $\alpha$ expression mice were treated with tamoxifen, to block IL-4R $\alpha$ signaling, after the clearance of a primary infection and then re-infected to analyze memory responses in the absence of IL-4R $\alpha$ expression. Mice treated with tamoxifen displayed a susceptible phenotype characterized by increased adult worm and larval burden, while the control mice with intact IL$4 \mathrm{R} \alpha$, treated under the same conditions, displayed a resistant profile (Nono et al., 2017). These studies detail the importance of IL-4R $\alpha$ expression in eliciting a proper host protective $\mathrm{Th} 2$ response.

Signal transducer and activation of transcription factor 6 (STAT6) is a member of the STAT family of transcription factors. Activation of STAT6 signaling is initiated by the binding of the cytokine ligands IL-4 or IL-13 to the shared cell surface receptor complex IL-4R $\alpha$. Ligation of the surface receptor activates Janus Kinase 2 (JAK2), which phosphorylates proteins. Janus kinase 2 utilizes adenosine triphosphate (ATP) to phosphorylate tyrosine residues on the intracytoplasmic region of IL-4R, thus switching on the pathway. Commonly, STAT6 molecules are found in the cytoplasm. Upon activation of JAK2, STAT6 molecules will attach to the phosphorylated tyrosine residue, allowing JAK2 to phosphorylate STAT6 proteins. 
Phosphorylation of STAT6 molecules promotes dimerization of STAT6 molecules and allows the complex to be translocated to the nucleus. The STAT6 complex will then bind to promoter regions of DNA and activate transcription genes with a STAT6 binding domain upstream of cytokine genes, leading to activation of Th2 responses (Oshea, 1997). Use of STAT6-deficient mice revealed the importance of STAT6 signaling in Th2 differentiation. The STAT6-deficient mice failed to elicit $\mathrm{T}$ cell differentiation as observed by the lack of IL-4 responses and the inability of B cells to produce IgE (Kaplan et al., 1996). The use of STAT6 pharmacological inhibitors in experiments have been vital in therapeutic discoveries and elucidation of Th2 immune mechanisms (Nagashima et al., 2006).

Previous studies suggest that human peripheral monocytes, IL-4/IL-13 production significantly downregulate expression of classical proinflammatory cytokines such as IFN $\gamma$, IL-1, IL-6, IL-8, IL-18, and TNF $\alpha$ in human peripheral monocytes (Chaitidis et al., 2005). Interleukin4 activation can recruit mediators of cell growth, resistance to apoptosis, and gene activation and differentiation. The development of Th2 cytokine-deficient mice provided an opportunity to investigate complex interactions between IL-4, IL-5, IL-9, and IL-13. T helper- type 2 cytokines, together, add to the rate and magnitude of responses to a pathogen, however, IL-4 alone has been shown to activate all Th2 effector functions (Fallon et al., 2002). A multitude of innate cells have been shown to be a source of IL-4 such as eosinophils, basophils, nuocytes, and mast cells (Seder et al., 1994; Van Panhuys et al., 2011). Innate cells early recruitment to the site of infection can deem them a source of early IL-4, which is necessary for Th2 differentiation indicative of parasite expulsion. Memory T-helper $\left(\mathrm{CD}^{+}\right) \mathrm{T}$ cells, during challenge infection, has been implicated as a sole source of IL-4 during helminth infection (Seder et al., 1994). Interleukin-4 stimulation initiates $\mathrm{CD}^{+} \mathrm{T}$ cell differentiation, which activates a cascade of the release of $\mathrm{Th} 2$ associated 
cytokines (Seder et al., 1992; Hsieh et al., 1992). Expression of IL-4 has been associated with decreases in IFN $\gamma$ producing $\mathrm{CD}^{+} \mathrm{T}$ cells (Coffman et al., 1986), promoting B cell class switching to express IgE, IgG, and $\operatorname{Ig} A$ (Vitetta et al., 1985), and has also been associated with the increased expression of major histocompatibility complex II (MHC II) in B cells (Noelle et al., 1984). Interleukin-4 signaling is crucial for $\mathrm{T}_{\mathrm{H}} 2$ cell differentiation. $\mathrm{T}$ cells from IL-4 deficient mice were used in a Nippostrongylus brasiliensis $(\mathrm{Nb})$ infection model to evaluate the requirement of IL-4 to mount an effective Th2 response. In the absence of IL-4, the levels of IL-5, IL-9, and IL-10 from isolated $\mathrm{CD}^{+}$cells were significantly reduced, which correlated with the reduced helminthinduced eosinophilia observed in vivo. However, the addition of IL-4 to the prestimulation culture of T cells induced the production of IL-5 and IL-10 from IL-4 ${ }^{-/-}$mice (Kopf et al., 1993). Thus, IL-4 presence is necessary for proper Th2 activation and to promote full host protective immunity to parasitic infection.

Nod-like receptor family, pyrin domain-containing 3 (NLRP3)

Nod-like receptors are found as inactive monomers within the cytoplasm of the cell. There are two types of nod-like receptors, the type is dependent upon its domain. The first domain is a pyrine domain and the second is a caspase recruitment domain. Common structural features of NLRs include leucine rich repeats (LRR), NACHT, and a domain. Monomers are inactive due to LRR blocking by a chaperone protein (Harton et al., 2002). The most studied NLR is Nod-like receptor family, pyrin domain-containing 3 (NLRP3) which is a cytoplasmic pattern recognition receptor (PRR), made up of seven NLRP3 monomers forming a ring-like structure, and adaptive proteins. The activation of NLRP3 follow the presence of agonists such as, potassium efflux, adenosine Triphosphate (ATP), transcription of proinflammatory cytokines, pathogen associated molecular patterns (PAMPs), danger associated molecular patterns (DAMPs), microbial products, endogenous molecules, viral products, and particulate matter (Inohara \& Nuñez, 2001). Activated 
NLRP3 bind adaptor proteins (ASC) constructed of a pyrine and a CARD domain undergoing oligomerization. The pyrine domain of ASC will bind the pyrine domain of NLRP3, while the CARD domain of ASC recruit protein monomers of procaspase-1 into proximity (Inohara \& Nuñez, 2001). At the completion of oligomerization, the constructed molecule is an inflammasome. The NLRP3 inflammasome is a protein complex that amplifies host immune response or can lead to cell pyroptosis. Procaspase-1 self-cleavage is activated by NLRP3 inflammasome presence, resulting in many active caspase-1 molecules. Caspase-1 can

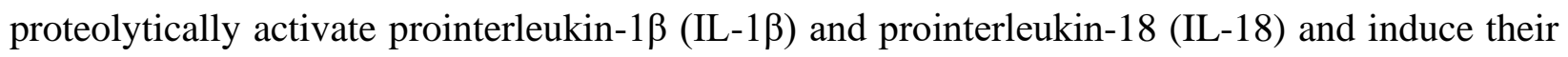
release (Martinon \& Burns et al., 2002).

The NLRP3 inflammasome has been implicated in response to various signals such as infection, tissue damage, and metabolic dysregulation (Bauernfeind et al., 2009). Due to the wide range of molecules with the potential to activate the inflammasome, its activation is tightly regulated. Activation entails a two-step process in which the first step requires priming of Tolllike receptor (TLR) and NLR ligands to enhance $\mathrm{NF}_{-} \mathrm{B}$ transcription of NLRP3 and the second step requires exposure to PAMPs, DAMPs, or crystalline substances to initiate NLRP3 inflammasome assembly (Bauernfeind et al., 2009). Inflammasome activation can induce pyroptosis upon infection with microbial pathogens. Water floods the cell, leading to swelling, and membrane rupture (Halle et al., 2008), Thus construction of the NLRP3 inflammasome is classically involved in pro-inflammatory responses and is pathological in the development of diseases such as, gout, Parkinson's, Inflammatory bowel disease, and Alzheimer's. Alzheimer's disease $(\mathrm{AD})$ is the most common neurodegenerative disease, characterized by dementia and progressive cognitive impairments. Pathologies associated with $\mathrm{AD}$ patients are $\mathrm{A} \beta$ plaques and neurofibrillary tangles found in the brain (Kinney et al., 2018). Localized neuroinflammation is 
the most reliable factor underlying $\mathrm{AD}$ pathogenesis, extracellular accumulation of amyloid- $\beta(\mathrm{A} \beta)$ in senile plaques is a critical event in $\mathrm{AD}$ pathogenesis (Hardy et al., 2002). Amyloid- $\beta$ presence induce microglia cell release of IL-1 $\beta$ in a caspase-1 dependent manner, causing the production of proinflammatory cytokines and inducing localized inflammation (Halle et al., 2008).

The construction of the NLRP3 protein complex is classically considered to be necessary for host response to bacterial infections such as, Mycoplasma pneumoniae, which causes both acute and chronic respiratory tract infections in humans (Waites et al., 2004). Infection of WT bone marrow-derived macrophages (BMDMs) with M. pneumoniae over the course of 16 hours resulted in a proinflammatory response characterized by increased secretion of IL-1 $\alpha$, IL-1 $\beta$, IL6 , and TNF- $\alpha$. Further investigation of BMDM responses in the context of M. pneumoniae infection revealed that in the absence of NLRP3 there was a reduction in IL- $1 \beta$ secretion across the 16-hour time course and a reduction in IL-6 cytokine secretion within the first 8 hours of infection. Similar results were observed when knocking out NLRP3-inflammasome components (caspase-1 and ASC), demonstrating the requirement for NLRP3-inflammasome during M. pneumoniae infection for the secretion of IL-1 $\beta$ and the induction of proinflammatory responses (Segovia et al., 2017).

Kinetic analysis of NLRP3 mRNA expression over a 24-hour time course in CD4 ${ }^{+} \mathrm{T}$ cells from wild-type (WT) mice after polarization $\left(\mathrm{T}_{\mathrm{H}} 0, \mathrm{~T}_{\mathrm{H}} 1, \mathrm{~T}_{\mathrm{H}} 2\right)$ revealed that at 12 hours NLRP3 expression was elevated in $\mathrm{T}_{\mathrm{H}} 0$ and $\mathrm{T}_{\mathrm{H}} 2$ cells, but not in $\mathrm{T}_{\mathrm{H}} 1$ cells. $\mathrm{CD}^{+} \mathrm{T}$ cells from NLRP3 ${ }^{-/-}$ mice were utilized to assess $\mathrm{T}_{\mathrm{H}} 1$ and $\mathrm{T}_{\mathrm{H}} 2$ polarization through expression levels of $\mathrm{IFN}_{\gamma}$ and IL-4 mRNA. The absence of NLRP3 reduced IL-4 expression but had no effect on IFN ${ }_{\gamma}$ expression in $\mathrm{CD}^{+} \mathrm{T}$ cells (Bruchard et al., 2015). Vaccination of WT, $\mathrm{NLRP3}^{--}$, $\mathrm{Casp}^{-}$, or $\mathrm{Asc}^{-}$mice with ovalbumin (OVA) plus a Toll-like receptor 2 ligand $\left(\mathrm{Pam}_{3} \mathrm{CSK}_{4}\right)$ resulted in impaired $\mathrm{T}_{\mathrm{H}} 2$ 
polarization in $\mathrm{NLRP}^{---}$mice. However, Casp1 ${ }^{-}$and $\mathrm{Asc}^{-}$had no effect on $\mathrm{T}_{\mathrm{H}} 2$ polarization as shown by the elevated concentration of IL-4 found in serum (Bruchard et al., 2015).

In the context of intracellular Leishmania major parasitic infection, a resistance phenotype is driven by a Th1 immune response, while a Th2 response results in a susceptible phenotype allowing disease progression (Scott et al., 1988). Infecting susceptible BALB/c mice with L. major lead to the activation of NLRP3 inflammasome in macrophages, further promoting the production of IL-1 $\beta$ and IL-18. Interluekin-18 production enhanced IL-4 secretion in activated T cells by increasing the expression of GATA3 and cMAF, leading to disease progression. The absence of NLRP3 inflammasome components resulted in less IL-18 and IL-4 significantly reducing parasite burden (Gurung et al., 2015). During murine infections with the extracellular parasite Nippostrongylus brasiliensis infection macrophage derived lung injury was driven by chitinaselike protein $\mathrm{Ym} 1$. Ym1 is highly induced in type 2 responses and plays a prominent role early in $N$. brasiliensis infection with the recruitment of neutrophils to the lung, promoting larval killing. Overexpression of $\mathrm{Ym} 1$ on the surface of alveolar macrophages drives IL-1 $\beta$ expression (Sutherland et al., 2018).

In the context of the gut dwelling extracellular parasite Trichuris muris NLRP3 has a major effect on the suppression of type 2 responses. Trichuris muris infection resulted in elevated IL-18 and suppression of protective adaptive and innate responses. The targeted inhibition of NLRP3 caused amelioration of disease as shown by decreased Th1 cytokines, elevated Th2 cytokines, accelerated worm expulsion, and a decrease in immunopathology's associated with disease (Alhallaf et al., 2018). The pharmacological inhibition of NLRP3 inflammasome with small molecule inhibitor MCC950 directly interacts with the Walker B motif within the NLRP3 NACHT 
domain, thereby blocking ATP hydrolysis and inhibiting NLRP3 activation and inflammasome formation (Coll RC et al., 2015).

\section{Concluding remarks}

Development of full host protective immune responses to elicit $H$. contortus parasite expulsion is widely carried out by the incorporation of cellular recruitment, antibody production, and cytokine secretion all largely under the Th2 arm of immune responses. The experiments contained throughout this dissertation serve to elucidate the role of NLRP3 in Th2 responses necessary for protection against $H$. contortus parasitic infection. Although the role of NLRP3 has been well characterized in a classical inflammatory setting, the function of NLRP3 during a type 2 response remains to be under investigation. During $N$. brasiliensis infection NLRP3 protein, independent of the inflammasome has shown a major effect on neutrophil recruitment, assisting in both larval killing and reduction in tissue damage (Chenery et al., 2019). This same trend was consistent with reports of NLRP3 protein independent of the inflammasome limiting neutrophil recruitment during bacterial lung infection with Francisella tularensis (Periasamy et al., 2016). RNA sequencing analysis of PBMC-derived from STC and SUF sheep cultured with HcLA revealed a significant upregulation in inflammatory associated genes such as, TLR4, NLRP3, IL$1 \beta$, and TLR2 (Jacobs et al., 2020).

Therefore, aims of the current study are (i) to create a working model to investigate breed differences in NLRP3 responses in a classical inflammatory setting (ii) investigate NLRP3 responses in the context of a $H$. contortus parasitic infection and (iii) understand the relationship between NLRP3 and IL-4 production during a parasitic infection. Further understanding of the role of NLRP3 in parasitic infection could lead to understanding differences observed in immune responses between parasite-resistant and parasite-susceptible sheep. These data could aid in future therapies to assist commercially favorable breeds in their response to H. contortus GIN infection. 


\section{Literature cited}

1. Alhallaf R, Agha Z, Miller CM, et al. The NLRP3 Inflammasome Suppresses Protective Immunity to Gastrointestinal Helminth Infection. Cell Rep. 2018;23(4):1085-1098. doi:10.1016/j.celrep.2018.03.097

2. Anthony RM, Rutitzky LI, Urban JF, Stadecker MJ, Gause WC. Protective immune mechanisms in helminth infection. Nat Rev Immunol. 2007;7(12):975-987. doi:10.1038/nri2199

3. Anthony RM, Urban JF, Alem F, et al. Memory TH2 cells induce alternatively activated macrophages to mediate protection against nematode parasites. Nat Med. 2006;12(8):955-960. doi:10.1038/nm1451

4. Armitage RJ, Fanslow WC, Strockbine L, et al. Molecular and biological characterization of a murine ligand for CD40. Nature. 1992;357(6373):80-82. doi:10.1038/357080a0

5. Balic A, Bowles VM, Meeusen ENT. Cellular pro®les in the abomasal mucosa and lymph node during primary infection with Haemonchus contortus in sheep. Vet Immunol Immunopathol. Published online 2000.

6. Barger IA, Jahbre LFL, GEomrt JR, Davies HI. REGULATION OF HAEiWONCHUS CONTORTUS POPULATIONS IN SHEEP EXPOSED TO CONTINUOUS INFECTION.

7. Barner M, Mohrs M, Brombacher F, Kopf M. Differences between IL-4R $\alpha$-deficient and IL-4-deficient mice reveal a role for IL-13 in the regulation of Th2 responses. Curr Biol. 1998;8(11):669-672. doi:10.1016/S0960-9822(98)70256-8

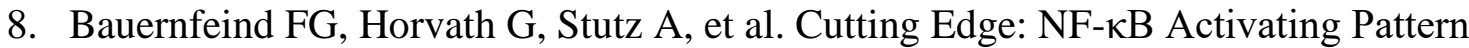
Recognition and Cytokine Receptors License NLRP3 Inflammasome Activation by 
Regulating NLRP3 Expression. J Immunol. 2009;183(2):787-791.

doi:10.4049/jimmunol.0901363

9. Besier RB, Kahn LP, Sargison ND, Van Wyk JA. The Pathophysiology, Ecology and Epidemiology of Haemonchus contortus Infection in Small Ruminants. In: Advances in Parasitology. Vol 93. Elsevier; 2016:95-143. doi:10.1016/bs.apar.2016.02.022

10. Bruchard M, Rebé C, Derangère V, et al. The receptor NLRP3 is a transcriptional regulator of TH2 differentiation. Nat Immunol. 2015;16(8):859-870. doi:10.1038/ni.3202

11. Chenery AL, Alhallaf R, Agha Z, et al. Inflammasome-Independent Role for NLRP3 in Controlling Innate Antihelminth Immunity and Tissue Repair in the Lung. J Immunol. 2019;203(10):2724-2734. doi:10.4049/jimmunol.1900640

12. Coffman R, Seymour B, Hudak S, Jackson J, Rennick D. Antibody to interleukin-5 inhibits helminth-induced eosinophilia in mice. Science. 1989;245(4915):308-310. doi:10.1126/science.2787531

13. Coffman RL, Ohara J, Bond MW, Carty J, Zlotnik A, Paul E. B cell stimulatory factor-1 enhances the IgE response of lipopolysaccharide-activated B cells.

14. Coll RC, Hill JR, Day CJ, et al. MCC950 directly targets the NLRP3 ATP-hydrolysis motif for inflammasome inhibition. Nat Chem Biol. 2019;15(6):556-559. doi:10.1038/s41589-019-0277-7

15. Ehigiator HN, Stadnyk AW, Lee TDG. Extract of Nippostrongylus brasiliensis Stimulates Polyclonal Type-2 Immunoglobulin Response by Inducing De Novo Class Switch. Mansfield JM, ed. Infect Immun. 2000;68(9):4913-4922. doi:10.1128/IAI.68.9.4913-4922.2000 
16. Escribano C, Saravia A, Costa M, et al. Resistance to Haemonchus contortus in Corriedale sheep is associated to high parasite-specific IgA titer and a systemic Th2 immune response. Sci Rep. 2019;9(1):19579. doi:10.1038/s41598-019-55447-6

17. Fallon PG, Jolin HE, Smith P, et al. IL-4 Induces Characteristic Th2 Responses Even in the Combined Absence of IL-5, IL-9, and IL-13. Immunity. 2002;17(1):7-17. doi:10.1016/S1074-7613(02)00332-1

18. Finkelman FD, Shea-Donohue T, Goldhill J, et al. CYTOKINE REGULATION OF HOST DEFENSE AGAINST PARASITIC GASTROINTESTINAL NEMATODES:Lessons from Studies with Rodent Models *. Annu Rev Immunol. 1997;15(1):505-533. doi:10.1146/annurev.immunol.15.1.505

19. Gause W. The immune response to parasitic helminths: insights from murine models. Trends Immunol. 2003;24(5):269-277. doi:10.1016/S1471-4906(03)00101-7

20. Gibbs HC. Mechanisms of survival of nematode parasites with emphasis on hypobiosis. Vet Parasitol. 1982;11(1):25-48. doi:10.1016/0304-4017(82)90119-4

21. Gill HS, Watson DL. Monoclonal antibody to CD4 + T cells abrogates genetic resistance to Haemonchus contortus in sheep.

22. Gurung P, Karki R, Vogel P, et al. An NLRP3 inflammasome-triggered Th2-biased adaptive immune response promotes leishmaniasis. J Clin Invest. 2015;125(3):13291338. doi:10.1172/JCI79526

23. Halle A, Hornung V, Petzold GC, et al. The NALP3 inflammasome is involved in the innate immune response to amyloid- $\beta$. Nat Immunol. 2008;9(8):857-865. doi:10.1038/ni.1636 
24. Hardy J. The Amyloid Hypothesis of Alzheimer's Disease: Progress and Problems on the Road to Therapeutics. Science. 2002;297(5580):353-356. doi:10.1126/science.1072994

25. Harton JA, Linhoff MW, Zhang J, Ting JP-Y. Cutting Edge: CATERPILLER: A Large Family of Mammalian Genes Containing CARD, Pyrin, Nucleotide-Binding, and Leucine-Rich Repeat Domains. J Immunol. 2002;169(8):4088-4093. doi:10.4049/jimmunol.169.8.4088

26. Holt RM, Shepherd EA, Ammer AG, Bowdridge SA. Effects of peripheral blood mononuclear cells on Haemonchus contortus larval motility in vitro. Parasite Immunol. 2015;37(10):553-556. doi:10.1111/pim.12219

27. Horsnell WGC, Vira A, Kirstein F, et al. IL-4R $\alpha$-responsive smooth muscle cells contribute to initiation of $\mathrm{TH} 2$ immunity and pulmonary pathology in Nippostrongylus brasiliensis infections. Mucosal Immunol. 2011;4(1):83-92. doi:10.1038/mi.2010.46

28. Howell SB, Burke JM, Miller JE, et al. Prevalence of anthelmintic resistance on sheep and goat farms in the southeastern United States. J Am Vet Med Assoc. 2008;233(12):1913-1919. doi:10.2460/javma.233.12.1913

29. Hsieh C-S, Heimberger AB, Gold JS, O’GARRAt A, Murphy KM. Differential regulation of T helper phenotype development by interleukins 4 and 10 in an c43 T-cellreceptor transgenic system. Proc Natl Acad Sci USA. Published online 1992.

30. Inohara N, Nuñez G. The NOD: a signaling module that regulates apoptosis and host defense against pathogens. Oncogene. 2001;20(44):6473-6481. doi:10.1038/sj.onc.1204787 
31. Jacobs JR, Greiner SP, Bowdridge SA. Impaired interleukin-4 signalling promotes establishment of Haemonchus contortus in sheep. Parasite Immunol. 2018;40(12):e12597. doi:10.1111/pim.12597

32. Jacobs JR, Middleton D, Greiner SP, Bowdridge SA. RNA-Sequencing of ovine PBMC after exposure to Haemonchus contortus larval antigen. Parasite Immunol. 2020;42(5). doi:10.1111/pim.12697

33. Kanhere A, Hertweck A, Bhatia U, et al. T-bet and GATA3 orchestrate Th1 and Th2 differentiation through lineage-specific targeting of distal regulatory elements. Nat Commun. 2012;3(1):1268. doi:10.1038/ncomms2260

34. Kaplan MH, Sun Y-L, Hoey T, Grusby MJ. Impaired IL-12 responses and enhanced development of Th2 cells in Stat4-deficient mice. Nature. 1996;382(6587):174-177. doi: $10.1038 / 382174 \mathrm{a} 0$

35. Kaplan MH, Sun Y-L, Hoey T, Grusby MJ. Impaired IL-12 responses and enhanced development of Th2 cells in Stat4-deficient mice. Nature. 1996;382(6587):174-177. doi: $10.1038 / 382174 \mathrm{a} 0$

36. Killar L, MacDonald G, West J, Woods A, Bottomly K. Cloned, Ia-restricted T cells that do not produce interleukin 4(IL 4)/B cell stimulatory factor 1(BSF-1) fail to help antigenspecific B cells.

37. Kinney JW, Bemiller SM, Murtishaw AS, Leisgang AM, Salazar AM, Lamb BT. Inflammation as a central mechanism in Alzheimer's disease. Alzheimers Dement Transl Res Clin Interv. 2018;4(1):575-590. doi:10.1016/j.trci.2018.06.014 
38. Kotze AC, Prichard RK. Anthelmintic Resistance in Haemonchus contortus. In: Advances in Parasitology. Vol 93. Elsevier; 2016:397-428. doi:10.1016/bs.apar.2016.02.012

39. Kreider T, Anthony RM, Urban JF, Gause WC. Alternatively activated macrophages in helminth infections. Curr Opin Immunol. 2007;19(4):448-453.

doi:10.1016/j.coi.2007.07.002

40. Lacroux C, Nguyen THC, Andreoletti O, et al. Haemonchus contortus (Nematoda: Trichostrongylidae) infection in lambs elicits an unequivocal $\mathrm{Th} 2$ immune response. Vet Res. 2006;37(4):607-622. doi:10.1051/vetres:2006022

41. Liu Q, Kreider T, Bowdridge S, et al. B Cells Have Distinct Roles in Host Protection against Different Nematode Parasites. J Immunol. 2010;184(9):5213-5223. doi:10.4049/jimmunol.0902879

42. MacKinnon KM, Bowdridge SA, Kanevsky-Mullarky I, Zajac AM, Notter DR. Gene expression profiles of hair and wool sheep reveal importance of Th2 immune mechanisms for increased resistance to Haemonchus contortus. J Anim Sci. 2015;93(5):2074-2082. doi:10.2527/jas.2014-8652

43. Madden KB, Whitman L, Sullivan C, et al. Role of STAT6 and Mast Cells in IL-4- and IL-13-Induced Alterations in Murine Intestinal Epithelial Cell Function. J Immunol. 2002;169(8):4417-4422. doi:10.4049/jimmunol.169.8.4417

44. Mandarapu R, Ajumeera R, Venkatesan V, Prakhya BM. Proliferation and T H 1/ T H 2 Cytokine Production in Human Peripheral Blood Mononuclear Cells after Treatment with Cypermethrin and Mancozeb In Vitro. J Toxicol. 2014;2014:1-8.

doi:10.1155/2014/308286 
45. Martinon F, Burns K. The Inflammasome: A Molecular Platform Triggering Activation of Inflammatory Caspases and Processing of proIL- $\square$. Mol Cell.

46. McKenzie GJ, Fallon PG, Emson CL, Grencis RK, McKenzie ANJ. Simultaneous Disruption of Interleukin (IL)-4 and IL-13 Defines Individual Roles in T Helper Cell Type 2-mediated Responses. J Exp Med. 1999;189(10):1565-1572. doi:10.1084/jem.189.10.1565

47. Mederos AE, Ramos Z, Banchero GE. First report of monepantel Haemonchus contortus resistance on sheep farms in Uruguay. Parasit Vectors. 2014;7(1):598. doi:10.1186/s13071-014-0598-z

48. Middleton D, Garza JJ, Greiner SP, Bowdridge SA. Neutrophils rapidly produce Th2 cytokines in response to larval but not adult helminth antigen. Parasite Immunol. 2020;42(1). doi:10.1111/pim.12679

49. Miller JE, Bahirathan M, Lemarie SL, Hembry FG, Kearney MT, Barras SR. Epidemiology of gastrointestinal nematode parasitism in Suffolk and Gulf Coast Native sheep with special emphasis on relative susceptibility to Haemonchus contortus infection. Vet Parasitol. 1998;74(1):55-74. doi:10.1016/S0304-4017(97)00094-0

50. Morimoto M, Morimoto M, Whitmire J, et al. Peripheral CD4 T Cells Rapidly Accumulate at the Host:Parasite Interface during an Inflammatory Th2 Memory Response. J Immunol. 2004;172(4):2424-2430. doi:10.4049/jimmunol.172.4.2424

51. Nishi C, Yanagihashi Y, Segawa K, Nagata S. MERTK tyrosine kinase receptor together with TIM4 phosphatidylserine receptor mediates distinct signal transduction pathways for efferocytosis and cell proliferation. J Biol Chem. 2019;294(18):7221-7230.

doi:10.1074/jbc.RA118.006628 
52. Noelle R, Krammer PH, Ohara J, Uhr JW, Vitetta ES. Increased expression of Ia antigens on resting B cells: an additional role for B-cell growth factor. Proc Natl Acad Sci. 1984;81(19):6149-6153. doi:10.1073/pnas.81.19.6149

53. Nono JK, Ndlovu H, Abdel Aziz N, Mpotje T, Hlaka L, Brombacher F. Interleukin-4 receptor alpha is still required after Th2 polarization for the maintenance and the recall of protective immunity to Nematode infection. MacDonald AS, ed. PLoS Negl Trop Dis. 2017;11(6):e0005675. doi:10.1371/journal.pntd.0005675

54. O'Connor LJ, Walkden-Brown SW, Kahn LP. Ecology of the free-living stages of major trichostrongylid parasites of sheep. Vet Parasitol. 2006;142(1-2):1-15. doi:10.1016/j.vetpar.2006.08.035

55. Owyang AM, Zaph C, Wilson EH, et al. Interleukin 25 regulates type 2 cytokinedependent immunity and limits chronic inflammation in the gastrointestinal tract. $J$ Exp Med. 2006;203(4):843-849. doi:10.1084/jem.20051496

56. Patel N, Kreider T, Urban JF, Gause WC. Characterisation of effector mechanisms at the host:parasite interface during the immune response to tissue-dwelling intestinal nematode parasites. Int J Parasitol. 2009;39(1):13-21. doi:10.1016/j.ijpara.2008.08.003

57. Paul WE. History of interleukin-4. Cytokine. 2015;75(1):3-7. doi:10.1016/j.cyto.2015.01.038

58. Peña MT, Miller JE, Horohov DW. Effect of dexamethasone treatment on the immune response of Gulf Coast Native lambs to Haemonchus contortus infection. Vet Parasitol. 2004;119(2-3):223-235. doi:10.1016/j.vetpar.2003.11.002 
59. Periasamy S, Le HT, Duffy EB, Chin H, Harton JA. Inflammasome-Independent NLRP3 Restriction of a Protective Early Neutrophil Response to Pulmonary Tularemia. Weiss D, ed. PLOS Pathog. 2016;12(12):e1006059. doi:10.1371/journal.ppat.1006059

60. Ritter M, Gross O, Kays S, et al. Schistosoma mansoni triggers Dectin-2, which activates the Nlrp3 inflammasome and alters adaptive immune responses. Proc Natl Acad Sci. 2010;107(47):20459-20464. doi:10.1073/pnas.1010337107

61. Roberts JL, Swan RA. Quantitative studies of ovine haemonchosis. I. Relationship between faecal egg counts and total worm counts. Vet Parasitol. 1981;8(2):165-171. doi:10.1016/0304-4017(81)90044-3

62. Roberts LS, Schmidt GD, Janovy J. Gerald D. Schmidt \& Larry S. Roberts' Foundations of Parasitology. 8th ed. McGraw-Hill Higher Education; 2009.

63. Roeber F, Jex AR, Gasser RB. Impact of gastrointestinal parasitic nematodes of sheep, and the role of advanced molecular tools for exploring epidemiology and drug resistance - an Australian perspective. Parasit Vectors. 2013;6(1):153. doi:10.1186/1756-3305-6153

64. Romagnani S. T-cell subsets (Th1 versus Th2). Ann Allergy Asthma Immunol. 2000;85(1):9-21. doi:10.1016/S1081-1206(10)62426-X

65. Saravia J, Chapman NM, Chi H. Helper T cell differentiation. Cell Mol Immunol. 2019;16(7):634-643. doi:10.1038/s41423-019-0220-6

66. Scott P, Natovitz P, Coffman RL, Pearce E, Sher A. Immunoregulation of cutaneous leishmaniasis. T cell lines that transfer protective immunity or exacerbation belong to different $\mathrm{T}$ helper subsets and respond to distinct parasite antigens. J Exp Med. 1988;168(5):1675-1684. doi:10.1084/jem.168.5.1675 
67. Seder RA, Paul WE, Davis MM. The Presence of Interleukln 4 during In Vitro Priming Determines the Lymphoklne-producing Potential of CD4 + T Cells from T Cell Receptor Transgenic Mice.

68. Segovia JA, Chang T-H, Winter VT, et al. NLRP3 Is a Critical Regulator of Inflammation and Innate Immune Cell Response during Mycoplasma pneumoniae Infection. Ehrt S, ed. Infect Immun. 2017;86(1):e00548-17. doi:10.1128/IAI.00548-17

69. Shakya KP, Miller JE, Horohov DW. A Th2 type of immune response is associated with increased resistance to Haemonchus contortus in naturally infected Gulf Coast Native lambs. Vet Parasitol. 2009;163(1-2):57-66. doi:10.1016/j.vetpar.2009.03.052

70. Shepherd EA, Garza JJ, Greiner SP, Bowdridge SA. The effect of ovine peripheral blood mononuclear cells on Haemonchus contortus larval morbidity in vitro. Parasite Immunol. 2017;39(4). doi:10.1111/pim.12424

71. Sutherland TE, Rückerl D, Logan N, Duncan S, Wynn TA, Allen JE. Ym1 induces RELM $\alpha$ and rescues IL-4R $\alpha$ deficiency in lung repair during nematode infection. Gause WC, ed. PLOS Pathog. 2018;14(11):e1007423. doi:10.1371/journal.ppat.1007423

72. Swain SL, Weinberg AD, English M, Huston G. IL-4 directs the development of Th2-like helper effectors.

73. Townsend MJ, Fallon PG, Matthews DJ, Smith P, Jolin HE, McKenzie ANJ. IL-9Deficient Mice Establish Fundamental Roles for IL-9 in Pulmonary Mastocytosis and Goblet Cell Hyperplasia but Not T Cell Development. Immunity. 2000;13(4):573-583. doi:10.1016/S1074-7613(00)00056-X 
74. Urban JF, Katona IM, Finkelman FD. Heligmosomoides polygyrus: CD4+ but not CD8+ T cells regulate the IgE response and protective immunity in mice. Exp Parasitol. 1991;73(4):500-511. doi:10.1016/0014-4894(91)90074-7

75. Urban JF, Noben-Trauth N, Donaldson DD, et al. IL-13, IL-4Ra, and Stat6 Are Required for the Expulsion of the Gastrointestinal Nematode Parasite Nippostrongylus brasiliensis.

76. Van Panhuys N, Prout M, Forbes E, Min B, Paul WE, Le Gros G. Basophils Are the Major Producers of IL-4 during Primary Helminth Infection. J Immunol. 2011;186(5):2719-2728. doi:10.4049/jimmunol.1000940

77. Vitetta ES, Ohara J, Myers CD, Layton JE, Krammer PH, Paul WE. Serological, biochemical, and functional identity of B cell-stimulatory factor 1 and B cell differentiation factor for IgG1. J Exp Med. 1985;162(5):1726-1731. doi:10.1084/jem.162.5.1726

78. Waites KB, Talkington DF. Mycoplasma pneumoniae and Its Role as a Human Pathogen. Clin Microbiol Rev. 2004;17(4):697-728. doi:10.1128/CMR.17.4.697-728.2004

79. Wynn TA. IL-13 E FFECTOR F UNCTIONS. Annu Rev Immunol. 2003;21(1):425-456. doi:10.1146/annurev.immunol.21.120601.141142

80. Zaiss MM, Maslowski KM, Mosconi I, Guenat N, Marsland BJ, Harris NL. IL-1ß Suppresses Innate IL-25 and IL-33 Production and Maintains Helminth Chronicity. Wilson M, ed. PLoS Pathog. 2013;9(8):e1003531. doi:10.1371/journal.ppat.1003531

81. Zhao A, McDermott J, Urban JF, et al. Dependence of IL-4, IL-13, and NematodeInduced Alterations in Murine Small Intestinal Smooth Muscle Contractility on Stat6 and Enteric Nerves. J Immunol. 2003;171(2):948-954. doi:10.4049/jimmunol.171.2.948 
82. Zhu J, Yamane H, Paul WE. Differentiation of Effector CD4 T Cell Populations. Annu Rev Immunol. 2010;28(1):445-489. doi:10.1146/annurev-immunol-030409-101212 


\section{Chapter 2: The role of NLRP3 in explaining sheep breed differences in response to LPS stimulation in vitro}

\section{Abstract}

Pathogen recognition is an essential component to achieve the desired outcome of full host protection. Nod-like receptor pyrin containing domain 3 (NLRP3) is a cytoplasmic pattern recognition receptor (PRR) with a wide array of agonists, such as PAMPs, DAMPs, ATP, bacterial product, and viral products. Stimulation of the NLRP3 inflammasome results in proteolytic activation of IL-1 $\beta$ and IL-18, cell pyroptosis, and classically, the induction of proinflammatory responses. St. Croix (STC) sheep exhibit the appropriate T-helper type 2 immune response ensuing full host protective immunity during helminth parasitic infection whereas parasite-susceptible Suffolk (SUF) sheep have an impaired response resulting in parasite establishment and adverse symptoms. St. Croix sheep are believed to be equipped with the ability to mount an effective immune response regardless of pathogen. The objective of these experiments was to investigate the role of NLRP3 in cellular immune responses to LPS treatment between peripheral blood mononuclear cells (PBMC) isolated from STC and SUF Sheep. PBMC derived from STC and SUF sheep were isolated from whole blood and stimulated for 3 hours with LPS or administered MCC950 or $1400 \mathrm{~W}$ for 2 hours before the addition of LPS to culture. qPCR analysis of LPSstimulated PBMC revealed breed differences as shown by an upregulation in inflammatory associated genes IL-1 $\beta(\mathrm{P}=0.004)$, TLR4 $(\mathrm{P}<0.001)$, TNF $\alpha(\mathrm{P}=0.009), \mathrm{NF} \mathrm{B}(\mathrm{P}=0.001)$ in STC PBMC and downregulation in IFNy, IL-6, IL-10, and iNOS for SUF PBMC. Pharmacological inhibition of NLRP3 and iNOS production in STC PBMC resulted in a significant reduction in IL4 protein concentrations in cell supernatant $(\mathrm{P}<.001)$. These preliminary data begin to discover a relationship between NLRP3 activation and TLR4 signaling in PBMC of STC and SUF sheep. 


\section{Introduction}

Amelioration of disease requires an adequate immune defense mechanism equipped to fight off invading pathogens. Pathogen recognition is the first step to the eradication of disease. Pattern recognition receptors (PRRs) are germline innate immune receptors that act as host defense alarmins and aid in the hosts ability to recognize conserved patterns on the surface of invading microorganisms, known as pathogen-associated molecular patterns (PAMPs) (Amarante-Mendes et al., 2018). In the case of gram-negative bacteria, lipopolysaccharide (LPS) is found in great abundance on the bacterial surface (May et al., 2018). The incorporation of LPS into in vitro cell culture methods model classic inflammatory responses as depicted by the secretion of proinflammatory associated cytokines such as, IL-1, IL-6, IL-8, IL-18, and TNF $\alpha$ (Chaitidis et al., 2005). Lipopolysaccharide binds toll like receptor-4 (TLR4) and activates downstream signaling events, resulting in the production of proinflammatory cytokines (Palsson-McDermott et al., 2004).

Proinflammatory responses reside under the T-helper type-1 (Th1) arm of immunity and are responsible for the killing of intracellular parasites, bacteria, viruses, and known for perpetuating autoimmune responses (Spellberg et al., 2000). Nod-like receptor family, pyrin domain-containing 3 (NLRP3) cytoplasmic pattern recognition receptors exist in monomeric form. Upon activation, seven monomers oligomerize to construct the NLRP3 inflammasome complex, which amplifies the host immune response and induce the maturation of IL-18 and IL-1 $\beta$ (Yang et al., 2019). The construction of NLRP3 inflammasome is classically involved in proinflammatory responses and is pathological in the development of diseases such as gout, M. pneumoniae (Segovia et al., 2017), and Alzheimer's (Halle et al., 2018). In the context of Nippostrongylus brasiliensis infection, NLRP3 protein revealed an inflammasome-independent role in helminth killing and transcriptional activation of type 2 immune responses (Chenery et al., 2019). 
Parasite-resistant St. Croix (STC) Sheep infected with the gastrointestinal helminth Haemonchus contortus display full host protective immunity with their ability to clear the parasitic infection without anthelmintic treatment (Mackinnon et al., 2010). Alternatively, Suffolk (SUF) sheep, while commercially favorable, fail to respond to larval stages, perpetuating adverse symptoms associated with disease (Alba-Hurtado and Munoz-Guzman et al., 2013). Specific immune responses to helminth infection can be best classified as T-helper type 2 (Th2) responses. Th2 immune activation to helminth larval stages reduce adult establishment and fecundity. Innate immune cell influx (eosinophils, mast cells, globule leukocytes), cytokine production (IL-4, IL-5, IL-13), and increased parasite-specific antibody (IgA, IgE) production are all implicated in parasite expulsion (Balic et al., 2000, Lacroux et al., 2006). RNA sequencing analysis of PBMC-derived from STC and SUF sheep cultured with HcLA revealed an upregulation in inflammatory associated genes, namely TLR2, TLR4, and NLRP3; and none were found to be upregulated in SUF PBMC (Jacobs et al., 2020).

RNA-sequencing from PBMC-derived from STC and SUF sheep were used to predict NLRP3 protein structure. When comparing the NLRP3 protein structures between STC and SUF sheep the predicted structures revealed vast differences. The objective of these studies was to observe the role of classic NLRP3 activation through stimulating cells from STC and SUF sheep with LPS. In the current study, we show that STC PBMC are equipped with the ability to mount an effective response to LPS challenge however, the inhibition of NLRP3 in STC PBMC reduced resulted in a significant reduction in response to LPS stimulation. These studies show a role for NLRP3 protein in STC PBMC host protective responses to bacterial agonist. 


\section{Materials and Methods \\ Experimental Design}

St. Croix (STC) (n=3) and Suffolk (SUF) sheep (n=3) were raised under parasite-free conditions at the West Virginia University Animal Science Farm to allow for controlled and monitored infection. Animals in this study were not exposed to $H$. contortus infection prior to experimental inoculation. Four weeks after weaning, animals received a single oral dose of 10,000 H. contortus infective stage larvae (L3). Infection persisted for six weeks before animals were dewormed using levamisole $(8 \mathrm{mg} / \mathrm{kg}$ ) and rested for three weeks. To create an experimental model that mimics a natural pasture infection, where animals are consistently exposed to L3, lambs were challenged infected. Following the rest period, lambs were challenged with an additional dose of 10,000 L3 which persisted for six weeks. Fecal egg count (FEC) and packed cell volume (PCV) were performed weekly throughout primary and challenge infection to monitor infection. At the time of experimentation lambs were primed, but not under active infection.

\section{Peripheral Blood Mononuclear Cell (PBMC)}

Whole blood samples were collected via jugular venipuncture into ( $\mathrm{n}=3$ tubes/breed) 10 ml EDTA treated vacutainer tubes (BD, Irvington, NJ). Peripheral blood mononuclear cell isolation was performed by centrifugation of blood samples at $400 \mathrm{xg}$ for $20 \mathrm{~min}$ at room temperature. Buffy coats were collected into a 15-ml sterile centrifuge tube suspended in 1-ml of sterile PBS (pH 7.4). Red blood cells were removed using ACK lysis buffer (Lonza, Walkersville, MD), and the resulting pellet was layered over sterile lymphocyte separation media (LSM) (Fisher Scientific, Hampton, $\mathrm{NH}$ ) and centrifuged at $400 \mathrm{x} g$ for 20 minutes at room temperature. Peripheral blood mononuclear cells were isolated and counted using TC-20 automated cell counter (Bio-RAD, Hercules, CA). Cells were diluted to a concentration of $1 \times 10^{6}$ cells $/ \mathrm{ml}$ for use in culture and suspended in complete media containing RPMI-1640 with 2 mmol/L L-glutamine, 10 
$\%$ fetal bovine serum (FBS), and Penicillin- Streptomycin-neomycin antibiotic (MilliporeSigma, Burlington, MA).

\section{RNA and cDNA preparation}

Peripheral blood mononuclear cells were plated in a sterile 24-well cell culture plate (Greiner bio-one, Monroe, NC) at 500,000 cells per well and incubated with antigen treatment for 3 hours at $37^{\circ} \mathrm{C}$ and $5 \% \mathrm{CO}_{2}$. Treatments consisted of Lipopolysaccharide- LPS (100 $\left.\mu \mathrm{g} / \mathrm{ml}\right)$ (Sigma-Aldrich, St. Louis, MO), $100 \mu \mathrm{g} / \mathrm{ml} \quad$ LPS with $10 \mu \mathrm{g} / \mathrm{ml}$ 1400W (N-(3[Aminomethyl]benzyl)acetamidine) (Sigma-Aldrich, St. Louis, MO), and $100 \mu \mathrm{g} / \mathrm{ml}$ LPS and MCC950- NLRP3 inhibitor (100 nm) (Invivogen, San Diego, CA). Treatments were run in triplicate. Following incubation, total RNA was isolated from antigen stimulated PBMC using Direct-zol RNA MiniPrep Plus (Zymo Research, Irvine, CA).

Briefly, cells were lysed in $300 \mu 1$ of RNAzol-Bee reagent (Tel-Test, Friendswood, TX). Lysate was filtered through a Zymo-spin column, DNA was digested using DNase. RNA was washed and dried on a silica membrane, then eluted into RNase-free water. Samples were analyzed on a BioTek plate reader (BioTek, Winooski, Vermont) measuring concentration and 260:280 for quality. Synthesis of cDNA was prepared using qScript XLT cDNA Supermix (Quantabio, Beverly, MA). Reactions were prepared in a 96 well PCR plate (VWR, Radnor, PA) by combining $4 \mu 1$ of $5 \mathrm{X}$ qScript XLT cDNA Supermix, $6 \mu 1$ of nuclease-free water, and $10 \mu \mathrm{l}$ of RNA template per well. The plate was then placed in T100 thermal cycler (Bio-Rad, Hercules, CA) with conditions at $25^{\circ} \mathrm{C}$ for $5 \mathrm{~min}, 42^{\circ} \mathrm{C}$ for $60 \mathrm{~min}$, and $85^{\circ} \mathrm{C}$ for $5 \mathrm{~min}$.

\section{Gene Expression}

\section{TaqMan Assays}

For qPCR, samples were made up of $10 \mu \mathrm{l} 2 \mathrm{X}$ TaqMan Gene Expression Master Mix (Applied Biosystems, Foster City, CA), $1 \mu 1$ of 20X TaqMan Gene Expression Assay 
(Glyceraldehyde 3-phosphate (GAPDH) - Bt03210913_g1 and Interleukin-4 (IL-4) Oa04927178_s1) (Applied Biosystems, Foster City, CA), $5 \mu 1$ of nuclease-free water, and $4 \mu \mathrm{l}$ (100 ng) cDNA template. Samples were analyzed in triplicate using CFX96 system (Bio-Rad, Hercules, CA). Conditions of qPCR were performed using the following thermal-cycler profile: 10 -minute hold at $95^{\circ} \mathrm{C}$, then 40 cycles of 15 seconds at $95^{\circ} \mathrm{C}$ denaturation and 1 -minute at $60^{\circ} \mathrm{C}$ extension. The reference gene used for normalization was Glyceraldehyde 3- phosphate dehydrogenase (GAPDH).

\section{SYBR Green}

qPCR reactions were run in triplicate with a Bio-Rad CFX96 system. Reaction conditions were: $50^{\circ} \mathrm{C}$ for 10 minutes and an initial denaturation at $95^{\circ} \mathrm{C}$ for 10 minutes followed by 40 cycles of denaturation at $95^{\circ} \mathrm{C}$ for 15 seconds, annealing for 30 seconds at $60^{\circ} \mathrm{C}$, and extension for $30 \mathrm{sec}$ at $72^{\circ} \mathrm{C}$. The PCR amplifications were carried out in a total volume of $20 \mu$, containing $10 \mu \mathrm{l} 2 \mathrm{X}$ Maxima SYBR Green qPCR master mix (Thermo Fisher Scientific, Waltham, MA), 1.2 $\mu l$ of each forward and reverse primers (IDT, Morrisville, NC), $2.6 \mu l$ of nuclease-free water, and $5 \mu \mathrm{l}$ of cDNA template.

The relative fold change in gene expression of candidate genes were done using the $2^{-\Delta \Delta C T}$ method (Livak and Schmittgen, 2001). The obtained $\mathrm{Ct}$ values were used to calculate $\Delta \mathrm{Ct}$ values for genes of interest [Ct (test) - Ct (reference)]. The reference gene used for normalization was GADPH. Graphical representation for each gene was based on fold change over complete media control treated groups. Primers were previously verified for equal efficiency in amplification.

\section{Proliferation Assay}

In preparation of culture, PBMC were plated at 250,000 cells per well in a sterile 24-well cell culture plate (Greiner bio-one, Monroe, NC) and antigen treatments were added and incubated at $37^{\circ} \mathrm{C}$ and $5 \% \mathrm{CO}_{2}$. Treatments consisted of Lipopolysaccharide- LPS (100 $\left.\mu \mathrm{g} / \mathrm{ml}\right)$ (Sigma- 
Aldrich, St. Louis, MO) and complete media. Treatments were run in triplicate. After a 24-hour incubation $100 \mu \mathrm{l}$ of Alamar blue reagent (Thermo Fisher Scientific, Waltham, MA) was added to each well. Forty-eight hours after the addition of Alamar blue, proliferation was quantified on a BioTek plate reader (BioTek, Winooski, Vermont) by reading absorbance at $570 \mathrm{~nm}$ and using $600 \mathrm{~nm}$ as a reference wavelength.

\section{Interleukin-1 $\beta$ ELISA}

Interleukin- $1 \beta$ protein was measured in culture supernatant following incubation of ovine PBMC with antigen treatment using an ovine specific IL-1 $\beta$ ELISA kit (MyBioSource, San Diego, CA, USA). Peripheral blood mononuclear cells were plated in a sterile 24 -well cell culture plate (Greiner bio-one, Monroe, NC) at 500,000 cells per well and incubated with antigen treatment for 3 hours at $37^{\circ} \mathrm{C}$ and $5 \% \mathrm{CO}_{2}$. Treatments consisted of Lipopolysaccharide- LPS (100 $\left.\mu \mathrm{g} / \mathrm{ml}\right)$ (Sigma-Aldrich, St. Louis, MO), LPS with 1400W (N-(3- [Aminomethyl]benzyl)acetamidine)iNOS inhibitor (Sigma-Aldrich, St. Louis, MO) at $10 \mu \mathrm{g} / \mathrm{ml}$, and LPS and MCC950- NLRP3 inhibitor (100 nm) (Invivogen, San Diego, CA). For inhibitor treated groups, cells were stimulated with pharmacological inhibitors for 2 hours prior to LPS stimulation. Treatments were run in triplicate. Following incubation, cellular supernatant was collected into microcentrifuge tubes, 10 $\mu \mathrm{l}$ of sample supernatant was added to the ovine specific IL-1 ELISA plate with $40 \mu \mathrm{l}$ of sample diluent and incubated for an hour. The process was carried out according to manufacturer's protocol. Samples were read at $450 \mathrm{~nm}$ and a standard curve was generated to detect IL-1 $\beta$ (0 to $600 \mathrm{pg} / \mathrm{ml}$ range).

\section{Interleukin-4 ELISA}

Concentration of IL-4 protein were detected in culture supernatant using ovine specific ELISA kits (MyBioSource, San Diego, CA, USA). Peripheral blood mononuclear cells were plated in a sterile 24-well cell culture plate (Greiner bio-one, Monroe, NC) at 500,000 cells per well and 
incubated with antigen treatment for 3 hours at $37^{\circ} \mathrm{C}$ and $5 \% \mathrm{CO}_{2}$. Treatments consisted of Lipopolysaccharide- LPS (100 $\mu \mathrm{g} / \mathrm{ml})$ (Sigma-Aldrich, St. Louis, MO), LPS with 1400W (N-(3[Aminomethyl]benzyl)acetamidine) (Sigma-Aldrich, St. Louis, MO) at $10 \mu \mathrm{g} / \mathrm{ml}$, and LPS and MCC950- NLRP3 inhibitor (100 nm) (Invivogen, San Diego, CA). For inhibitor treated groups, cells were stimulated with pharmacological inhibitors for 2 hours prior to LPS stimulation. Treatments were run in triplicate. Following incubation, cellular supernatant was collected into microcentrifuge tubes, $100 \mu \mathrm{l}$ of sample supernatant was added to the ovine specific IL-4 ELISA plate and incubated for an hour. The process was carried out according to manufacturer's protocol. Samples were read at $450 \mathrm{~nm}$ and a standard curve was generated to detect IL-4 (6.25 to $400 \mathrm{pg} / \mathrm{mL}$ range).

\section{Nitric Oxide assay}

Nitric oxide free radical was measured in sample supernatant by measuring the concentration of nitrite in cellular supernatant using the Griess Reagent System kit (Promega, Madison, WI). Peripheral blood mononuclear cells were plated in a sterile 24-well cell culture plate (Greiner bio-one, Monroe, NC) at 500,000 cells per well and incubated with antigen treatment for 3 hours at $37^{\circ} \mathrm{C}$ and $5 \% \mathrm{CO}_{2}$. Treatments consisted LPS $(100 \mu \mathrm{g} / \mathrm{ml})$, LPS with 1400W (N-(3- [Aminomethyl]benzyl)acetamidine) (Sigma-Aldrich, St. Louis, MO) at $10 \mu \mathrm{g} / \mathrm{ml}$, and LPS and MCC950- NLRP3 inhibitor (100 nm) (Invivogen, San Diego, CA). For inhibitor treated groups, cells were stimulated with pharmacological inhibitors for 2 hours prior to LPS stimulation. Treatments were run in triplicate. Following incubation, cellular supernatant was collected into microcentrifuge tubes, $50 \mu \mathrm{l}$ of sample supernatant was added to a 96-well cell culture plate. The process was carried out according to manufacturer's protocol. Samples were read at $540 \mathrm{~nm}$ and a standard curve was generated to detect nitrite ( 0 to $100 \mu \mathrm{M}$ range). 


\section{Statistics}

Sigma Plot software version 14.5 was used for statistical analysis. Statistical analysis for qPCR data was based on fold change values, results were normalized to both control group and GAPDH and reported as fold change. A two-way ANOVA with fixed effects of breed and treatment was used to assess breed differences in response to LPS stimulation or the incorporation pharmacological inhibitors MCC950 and 1400W to culture. The Holm-sidak post hoc test was utilized for means comparison. A two-way ANOVA with fixed effects of breed and treatment was used to assess proliferation and protein assays. The Holm-sidak post hoc test was used for means comparison. Differences were considered significant if $\mathrm{P}<0.05$ for all experiments.

\section{Results}

\section{PBMC gene expression after 3-hour LPS stimulation}

Gene expression analysis was performed to evaluate breed differences in genes associated with the activation of the LPS signaling pathway. Peripheral blood mononuclear cells were isolated from whole blood and plated at 500,000 cells per well and cultured with CM or $100 \mu \mathrm{g} / \mathrm{ml} \mathrm{LPS}$ for 3 hours. Stimulation of STC PBMC with LPS resulted in a breed effect with a significant upregulation in TLR4 (figure 2.1A) (P < 0.001), NFkB $(\mathrm{P}<0.001)$ (figure 2.1B), IL-1 $\beta(\mathrm{P}<0.01)$ (figure 2.1C), and TNF $\alpha(\mathrm{P}<0.01)$ (figure 2.1D) genes as compared to SUF PBMC. There were no significant differences observed in the expression of IFN $\gamma$, IL-6, IL-12B, TLR2, IL-10, and iNOS within PBMC from both breeds.

\section{Effects of NLRP3 and iNOS inhibition on PBMC responses to LPS}

Gene expression analysis of PBMC from STC and SUF sheep was performed to analyze the effect of the addition of pharmacological inhibitors $100 \mathrm{~nm}$ MCC950 (NLRP3 inhibitor) or 10 $\mu \mathrm{g} / \mathrm{ml} 1400 \mathrm{~W}$ (iNOS inhibitor) to culture. Administering MCC950 to STC PBMC in an LPS model resulted in a treatment effect observed by a significant reduction in the expression of TLR4 $(\mathrm{P}<0.001)$ (figure 2.2A), NFkB $(\mathrm{P}<0.001)$ (figure 2.2B), IL-1 $\beta(\mathrm{P}<0.001)$ (figure 2.2C), and 
TNFa $(\mathrm{P}<0.001$ ) (figure 2.2D) gene expression as compared to SUF PBMC. The addition of 1400W to LPS culture in STC PBMC resulted in a treatment effect with a significant reduction of TLR4 $(\mathrm{P}<0.001)$ (figure 2.3A), IL-1 $\beta \quad(\mathrm{P}<0.05)$ (figure 2.3C), and TNF $\alpha(\mathrm{P}<0.05)$ (figure 2.3D). However, the inhibition of iNOS production in STC PBMC resulted in a significant upregulation in the expression of $\mathrm{NFkB}(\mathrm{P}<0.001)$ (figure 2.3B). The incorporation of $1400 \mathrm{~W}$ to LPS culture had no significant effect on SUF PBMC.

\section{Cytokine production in response to LPS stimulation}

To determine breed differences in IL-1 $\beta$ and IL-4 protein concentrations in cellular supernatant, PBMC were isolated from whole blood and stimulated with LPS, LPS and MCC950, or LPS and $1400 \mathrm{~W}$. There were no breed differences observed in the measure of IL-1 $\beta$ protein production following PBMC stimulation. However, the stimulation of PBMC from both STC and SUF PBMC with LPS resulted in a significant increase in IL-1 $\beta$ protein production $(\mathrm{P}<0.001)$ (figure 2.4A). The addition of the pharmacological inhibitor MCC950 to culture resulted in a significant reduction in the secretion of $\mathrm{IL}-1 \beta$ protein in cellular supernatant $(\mathrm{P}<0.001)$ (figure 2.4A) for both breeds. The addition of $1400 \mathrm{~W}$ to LPS culture resulted in a similar trend with a significant reduction observed in IL-1 $\beta$ production $(\mathrm{P}<0.001)$ (figure 2.4B). Interleukin-4 protein in cellular supernatant following LPS stimulation resulted in a significant increase in IL-4 secretion in STC PBMC (P < 0.001) as compared to SUF PBMC (figure 2.5A). The incorporation of MCC950 to cell culture resulted in a significant reduction in IL-4 cellular secretion in STC PBMC $(\mathrm{P}<0.001$ ) and no significant changes observed in SUF PBMC (figure 2.5B). A similar trend in IL-4 protein production was observed when $1400 \mathrm{~W}$ was added to LPS culture, STC had a significant reduction in IL-4 protein in cellular supernatant $(\mathrm{P}<0.001)$, while SUF PBMC had no significant changes in IL-4 protein secretion (figure 2.5C). 
Proliferation assays were performed to assess breed differences in cellular responses to LPS stimulation. Although no significant differences were observed, without a stimulus STC PBMC have a greater proliferative response however, with the addition of an LPS stimulus to culture SUF PBMC have a greater proliferative response than STC PBMC (figure 2.7). Cell culture supernatant was utilized to measure the amount of nitrite free radical in cellular supernatant. After 3 hours of LPS stimulation there were no breed differences observed in nitrite concentrations (figure 2.6A). The addition of the pharmacological inhibitors MCC950 or 1400W to LPS culture resulted in a similar trend with significant reduction in nitrite concentrations found in culture supernatant $(\mathrm{P}<0.001)$ (figure 2.6B, 2.6C).

\section{Discussion}

Construction of the NLRP3 inflammasome is classically involved in pro-inflammatory responses and is pathological in the development of diseases such as, gout, Parkinson's, Inflammatory bowel disease, and Alzheimer's. These experiments work to identify a role for NLRP3 in an in vitro LPS model of infection with the use of PBMC isolated from parasite-resistant STC and parasite-susceptible SUF breeds of sheep. St. Croix sheep have been largely studied in parasite infections as a model for full host protective immunity (Alba-Hurtado and MunozGuzman et al., 2013). Suffolk sheep on the contrary have presented delayed responses to parasitic challenge, resulting in adverse symptoms associated with disease (Miller et al., 1998). Lipopolysaccharide (LPS) endotoxin is the outer membrane component of Gram-negative bacteria, LPS contributes to the structural integrity and protection from chemical attacks on Gramnegative bacteria (May et al., 2018). The administration of LPS elicits a strong immune response, phenotypically characterized by the extensive production of proinflammatory cytokines such as IL-1, IL-12, IFN $\gamma$, and TNF $\alpha$ (Chaitidis et al., 2005). Following an LPS challenge of Dorset and SUF sheep, SUF PBMC revealed enhanced proinflammatory associated genes, portraying a 
possible predisposition to bacterial infections (Hadfield et al., 2018). An in vivo study of LPS administration presented a higher resting serum nitric oxide concentration in SUF sheep (data not published). We hypothesized that STC PBMC were better equipped with a Th2 phenotype, while SUF PBMC were equipped with a Th1 phenotype; similar to C57BL/6 and BALB/c mice (Watanabe et al., 2004).

In our in vitro LPS model of infection using PBMC from STC and SUF sheep, gene expression analysis revealed an upregulation of all genes associated with the LPS signaling pathway. Whereas, the stimulation of SUF PBMC with LPS resulted in no significant differences observed. Suffolk PBMC are having trouble turning on the LPS signaling pathway and responding to the stimulus. The lack of response can be a result of either the need for longer culturing time points to allow SUF cells the ability to mount an effective response or it is possible that the deficiency in early responses is due to structural differences observed in NLRP3 protein (data not published) or signaling events upstream or downstream NLRP3. This same trend in the inability of SUF sheep to respond early to pathogenic challenge has been observed in Haemonchus contortus infection, where there was a 7-day delay in IL-4 expression within the abomasal tissue as compared to STC sheep (Jacobs et al., 2018). The trends observed in the expression of IL-1 $\beta$ was not mimicked in protein measured in cellular supernatant following LPS antigen stimulation. This could be a result of immune cells utilizing alternate mechanisms of IL-1 $1 \beta$ production to ensure its protein presence. However, when measuring the concentration of IL-4 in cellular supernatant after LPS challenge, STC PBMC produced significant greater amounts of IL-4 as compared to SUF PBMC.

Our data revealed the pharmacological inhibition of NLRP3 in STC PBMC resulted in a reduction in the expression of genes associated with the LPS signaling pathway, STC responses 
were reduced to responses comparable to SUF PBMC stimulated with LPS. The inhibition of NLRP3 in SUF PBMC resulted in no significant difference in gene expression from LPS stimulated cells. However, when observing IL-4 protein production following NLRP3 inhibition STC PBMC had a reduction in IL-4 production, while the SUF PBMC had no effect. Jacobs et al., 2020 RNA sequencing analysis of PBMC stimulated with Haemonchus contortus larval antigen revealed STC PBMC to have an upregulation in proinflammatory associated genes such as, TLR4, TLR2, and NLRP3. The use of RNA sequenced reads for the NLRP3 transcript was utilized to predict protein structure. Predicted software revealed differences in the NLRP3 primary protein structure between STC and SUF breeds. Further investigation of the impact of NLRP3 structural differences on immune responses to pathogenic challenge will need to be performed. Lipopolysaccharide is the ligand for toll-like receptor 4 (TLR4). Binding of LPS to TLR-4 activates downstream signaling events, including the activation of mitogen-activated protein kinase (MAPK) and nuclear factor- $\mathrm{B}(\mathrm{NF \kappa B})$ pathways in macrophage (Palsson-McDermott et al., 2004). The activation of NFאB is the first signal in the construction of NLRP3 inflammasome (Bauernfeind et al., 2009). The significant increase in TLR4 expression observed in STC PBMC as compared to SUF PBMC reveal a possible role for the TLR4 pathway in early immune activation in parasite resistant STC PBMC. Further investigation of the TLR4 pathway are necessary, these data demonstrate the consequences of loss of function of downstream signaling event in NLRP3, however, investigation of upstream activation events are necessary. These experiments provide a working in vitro LPS model for the role of NLRP3 in PBMC derived from STC and SUF sheep. 


\section{Literature Cited}

1. Bauernfeind, F. G., Horvath, G., Stutz, A., Alnemri, E. S., MacDonald, K., Speert, D., Fernandes-Alnemri, T., Wu, J., Monks, B. G., Fitzgerald, K. A., Hornung, V., \& Latz, E. (2009). Cutting Edge: NF-кB Activating Pattern Recognition and Cytokine Receptors License NLRP3 Inflammasome Activation by Regulating NLRP3 Expression. The Journal of Immunology, 183(2), 787-791. https://doi.org/10.4049/jimmunol.0901363

2. Besier, R. B., Kahn, L. P., Sargison, N. D., \& Van Wyk, J. A. (2016). The Pathophysiology, Ecology and Epidemiology of Haemonchus contortus Infection in Small Ruminants. In Advances in Parasitology (Vol. 93, pp. 95-143). Elsevier. https://doi.org/10.1016/bs.apar.2016.02.022

3. Bruchard, M., Rebé, C., Derangère, V., Togbé, D., Ryffel, B., Boidot, R., Humblin, E., Hamman, A., Chalmin, F., Berger, H., Chevriaux, A., Limagne, E., Apetoh, L., Végran, F., \& Ghiringhelli, F. (2015). The receptor NLRP3 is a transcriptional regulator of TH2 differentiation. Nature Immunology, 16(8), 859-870. https://doi.org/10.1038/ni.3202

4. Escribano, C., Saravia, A., Costa, M., Castells, D., Ciappesoni, G., Riet-Correa, F., \& Freire, T. (2019). Resistance to Haemonchus contortus in Corriedale sheep is associated to high parasite-specific IgA titer and a systemic Th2 immune response. Scientific Reports, 9(1), 19579. https://doi.org/10.1038/s41598-019-55447-6

5. Gibbs, H. C. (1982). Mechanisms of survival of nematode parasites with emphasis on hypobiosis. Veterinary Parasitology, 11(1), 25-48. https://doi.org/10.1016/03044017(82)90119-4

6. Gurung, P., Karki, R., Vogel, P., Watanabe, M., Bix, M., Lamkanfi, M., \& Kanneganti, T.-D. (2015). An NLRP3 inflammasome-triggered Th2-biased adaptive immune 
response promotes leishmaniasis. Journal of Clinical Investigation, 125(3), 1329-1338. https://doi.org/10.1172/JCI79526

7. Harton, J. A., Linhoff, M. W., Zhang, J., \& Ting, J. P.-Y. (2002). Cutting Edge: CATERPILLER: A Large Family of Mammalian Genes Containing CARD, Pyrin, Nucleotide-Binding, and Leucine-Rich Repeat Domains. The Journal of Immunology, 169(8), 4088-4093. https://doi.org/10.4049/jimmunol.169.8.4088

8. Inohara, N., \& Nuñez, G. (2001). The NOD: A signaling module that regulates apoptosis and host defense against pathogens. Oncogene, 20(44), 6473-6481. https://doi.org/10.1038/sj.onc. 1204787

9. Kaplan, M. H., Sun, Y.-L., Hoey, T., \& Grusby, M. J. (1996). Impaired IL-12 responses and enhanced development of Th2 cells in Stat4-deficient mice. Nature, 382(6587), 174177. https://doi.org/10.1038/382174a0

10. Kopf, M., Grost, G. L., Bachmann, M., Lamers, M. C., Bluethmann, H., \& KOhler, G. (1993). Disruption of the murine IL-4 gene blocks Th2 cytokine responses. 362, 4.

11. Martinon, F., \& Burns, K. (n.d.). The Inflammasome: A Molecular Platform Triggering Activation of Inflammatory Caspases and Processing of proIL-N L. Molecular Cell, 10.

12. Middleton, D., Garza, J. J., Greiner, S. P., \& Bowdridge, S. A. (2020). Neutrophils rapidly produce Th2 cytokines in response to larval but not adult helminth antigen. Parasite Immunology, 42(1). https://doi.org/10.1111/pim.12679

13. O'Connor, L. J., Walkden-Brown, S. W., \& Kahn, L. P. (2006). Ecology of the freeliving stages of major trichostrongylid parasites of sheep. Veterinary Parasitology, 142(1-2), 1-15. https://doi.org/10.1016/j.vetpar.2006.08.035 
14. Roberts, J. L., \& Swan, R. A. (1981). Quantitative studies of ovine haemonchosis. I. Relationship between faecal egg counts and total worm counts. Veterinary Parasitology, 8(2), 165-171. https://doi.org/10.1016/0304-4017(81)90044-3

15. Roberts, L. S., Schmidt, G. D., \& Janovy, J. (2009). Gerald D. Schmidt \& Larry S. Roberts'foundations of parasitology (8th ed). McGraw-Hill Higher Education.

16. Roeber, F., Jex, A. R., \& Gasser, R. B. (2013). Impact of gastrointestinal parasitic nematodes of sheep, and the role of advanced molecular tools for exploring epidemiology and drug resistance_-An Australian perspective. Parasites \& Vectors, 6(1), 153. https://doi.org/10.1186/1756-3305-6-153

17. Scott, P., Natovitz, P., Coffman, R. L., Pearce, E., \& Sher, A. (1988). Immunoregulation of cutaneous leishmaniasis. $\mathrm{T}$ cell lines that transfer protective immunity or exacerbation belong to different $\mathrm{T}$ helper subsets and respond to distinct parasite antigens. The Journal of Experimental Medicine, 168(5), 1675-1684. https://doi.org/10.1084/jem.168.5.1675

18. Segovia, J. A., Chang, T.-H., Winter, V. T., Coalson, J. J., Cagle, M. P., Pandranki, L., Bose, S., Baseman, J. B., \& Kannan, T. R. (2017). NLRP3 Is a Critical Regulator of Inflammation and Innate Immune Cell Response during Mycoplasma pneumoniae Infection. Infection and Immunity, 86(1), e00548-17. https://doi.org/10.1128/IAI.0054817

19. Swain, S. L., Weinberg, A. D., English, M., \& Huston, G. (n.d.). IL-4 directs the development of Th2-like helper effectors.

20. Van den Brom, R., Moll, L., Kappert, C., \& Vellema, P. (2015). Haemonchus contortus resistance to monepantel in sheep. Veterinary Parasitology, 209(3-4), 278-280. https://doi.org/10.1016/j.vetpar.2015.02.026 
A.

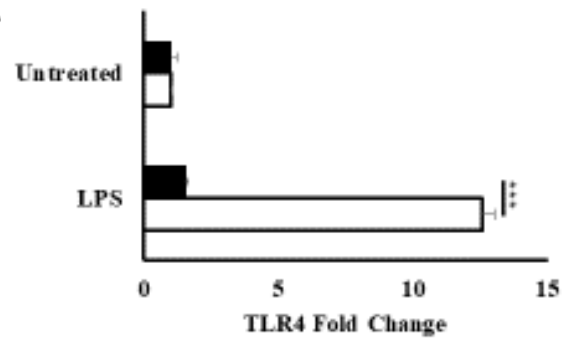

D.

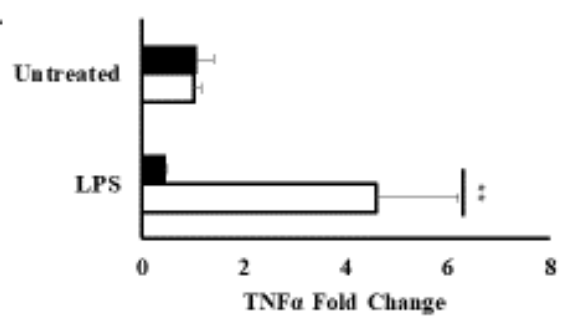

G.

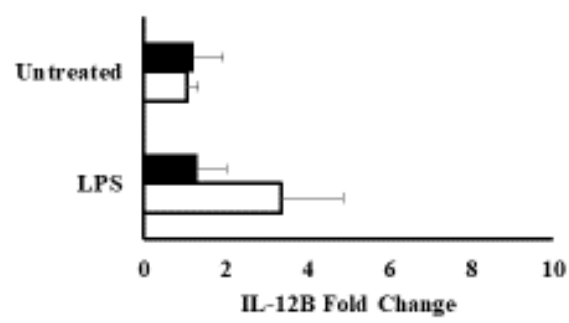

J.

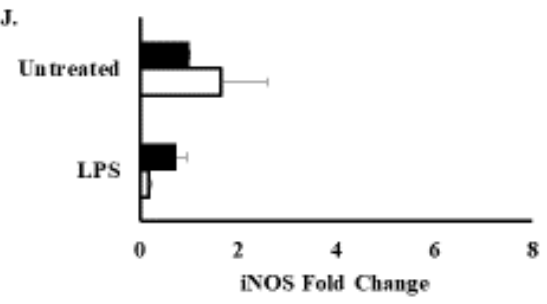

B.

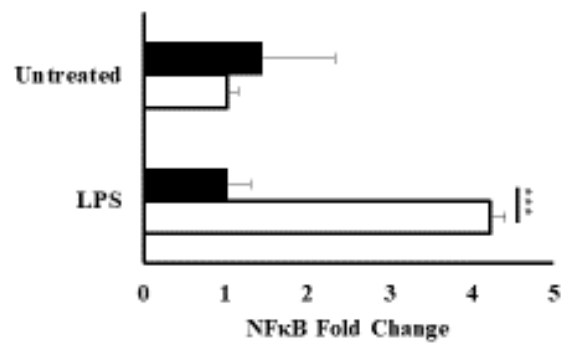

E.

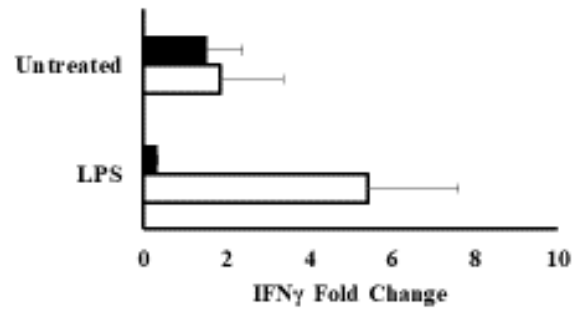

H.

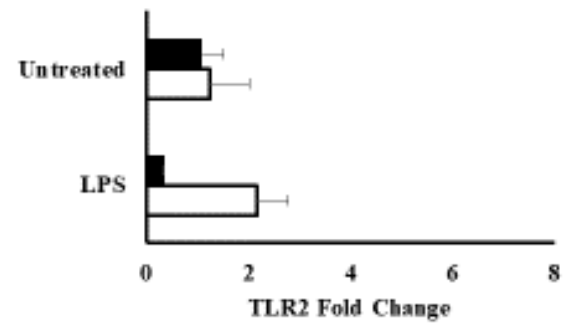

c.

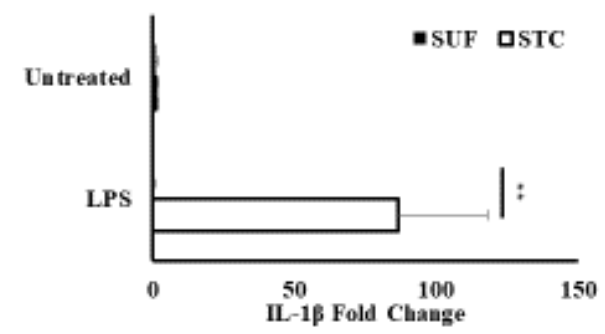

F.

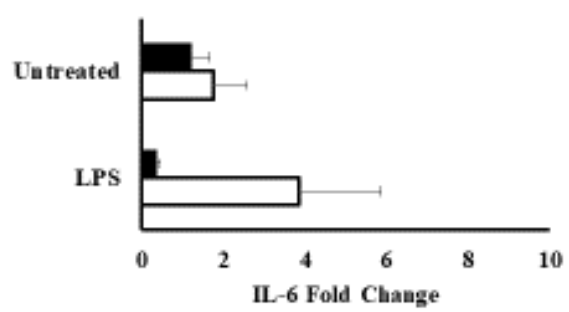

I.

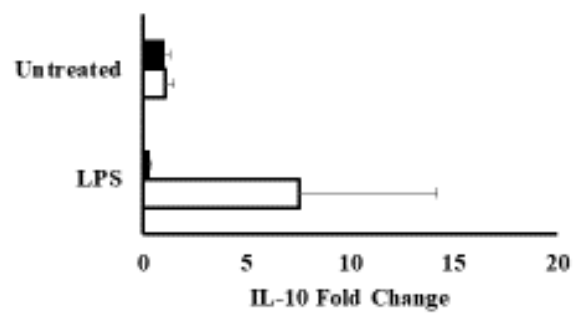

Figure 2.1: Gene expression analysis of PBMC after 3 hours LPS culture

PBMC-derived from STC and SUF sheep were isolated from whole blood and cultured with complete media (untreated) or $100 \mu \mathrm{g} / \mathrm{ml}$ of lipopolysaccharides (LPS) at $37^{\circ} \mathrm{C}$ and $5 \% \mathrm{CO}_{2}$ for 3 hours, gene expression was measured. Fold change was calculated using the $\Delta$ ct relative to housekeeping gene GAPDH and $2^{-\triangle \Delta C T}$ relative to cells culture media. Error bars represent SEM. Each treatment was performed in triplicate. Significance was accepted at $\mathrm{P}<0.05$. $* * \mathrm{P}<0.01$, $* * * \mathrm{P}<0.001$. 
A.

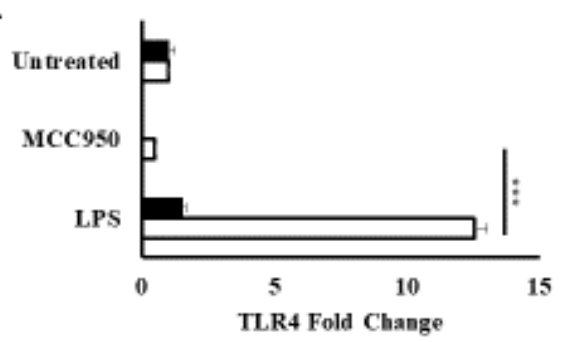

D.

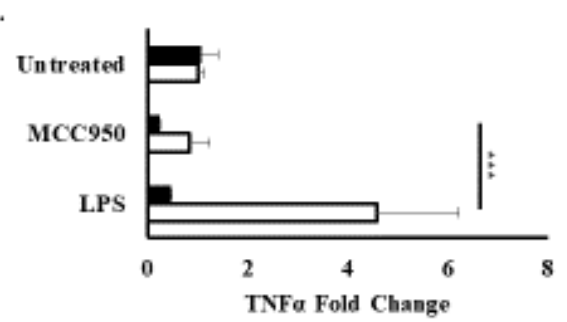

G.
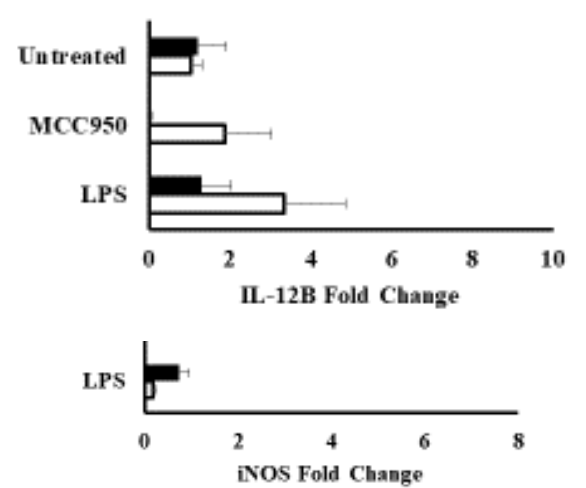

B.

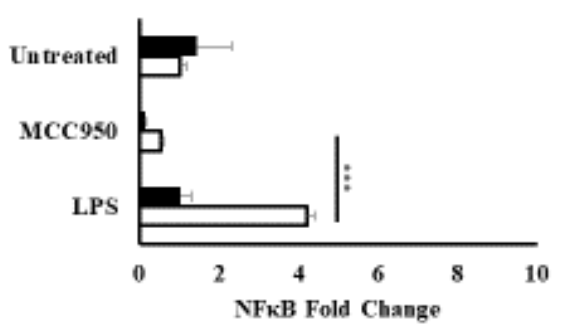

E.

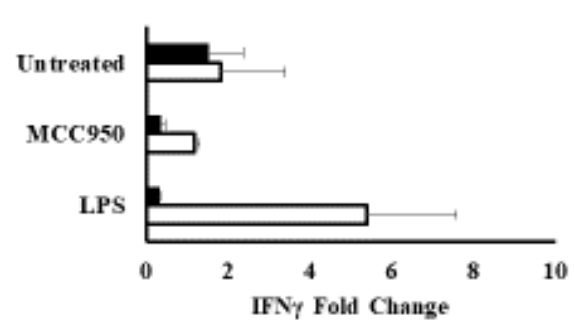

H.

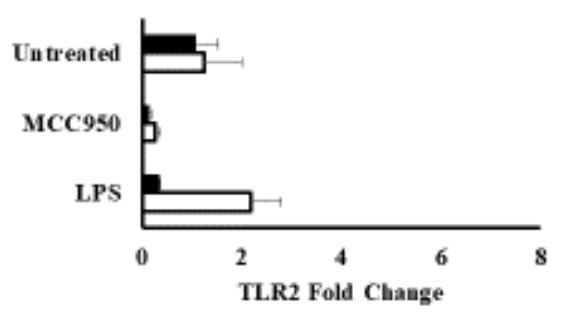

c.

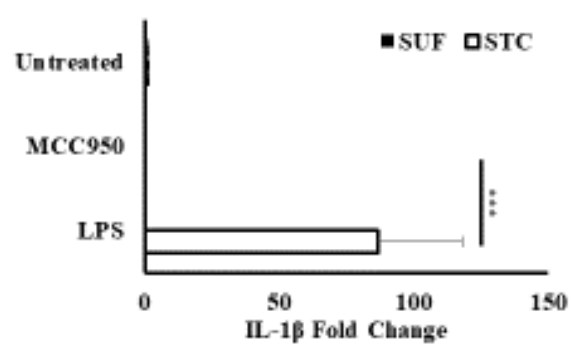

F.

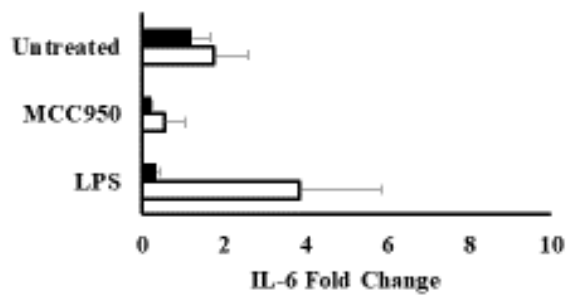

I.

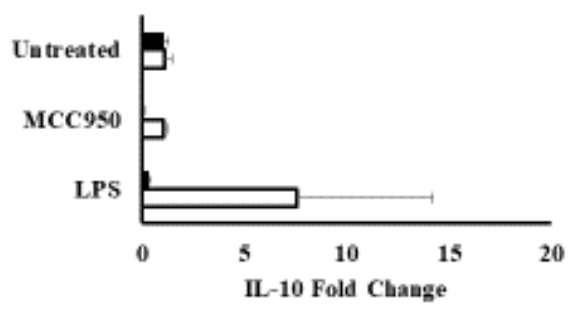

Figure 2.2: Inhibition of NLRP3 inflammasome formation in PBMC stimulated with LPS PBMC derived from STC and SUF sheep were isolated from whole blood and cultured with 100 nm MCC950 sodium NLRP3 inhibitor for two hours, before adding $100 \mu \mathrm{g} / \mathrm{ml}$ LPS to culture. Cells were cultured for 3 hours with LPS at $37^{\circ} \mathrm{C}$ and $5 \% \mathrm{CO}_{2}$, then gene expression was measured. Fold change was calculated using the $\Delta \mathrm{ct}$ relative to housekeeping gene GAPDH and $2^{-\triangle \Delta C T}$ relative to cells culture in complete media (Untreated) or DMSO treated cells for inhibited groups. Error bars represent SEM. Each treatment was performed in triplicate. Significance was accepted at $\mathrm{P}<0.05$. $* * * \mathrm{P}<0.001$. 
A.

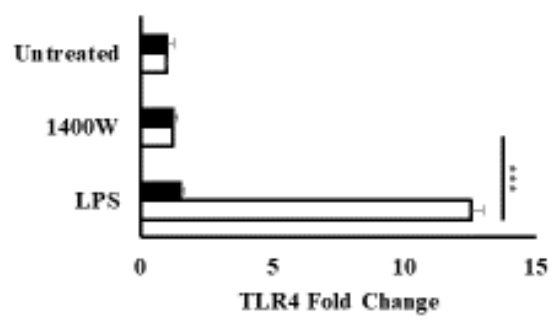

D.

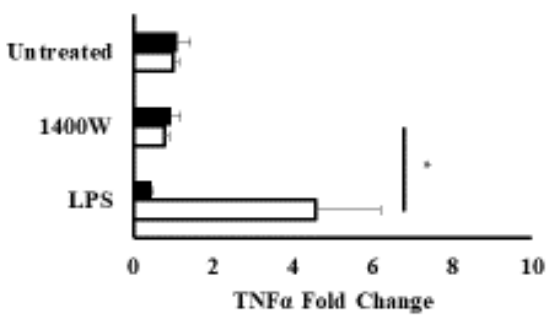

G.

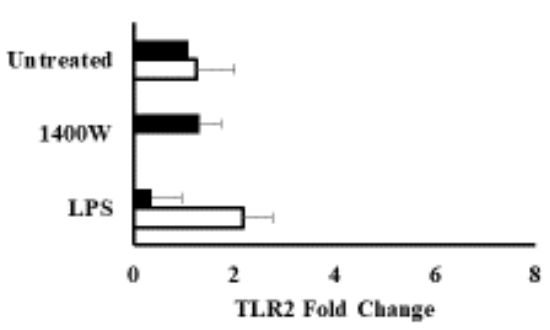

B.

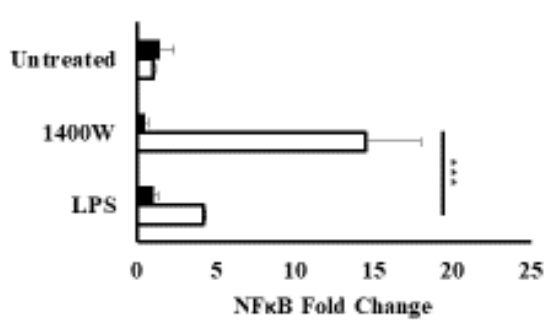

E.

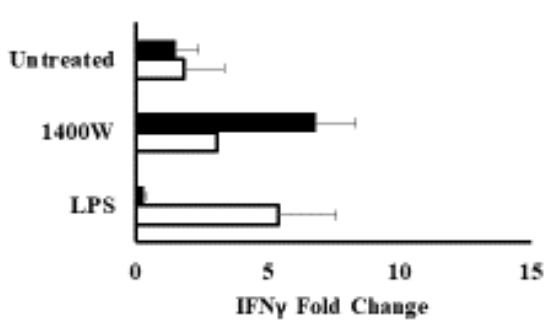

H.

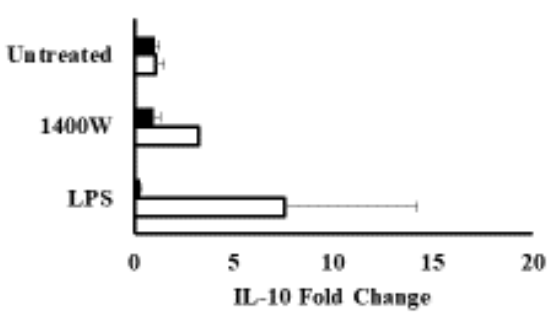

c.

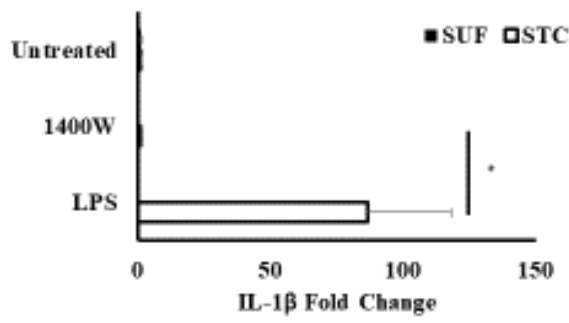

F.

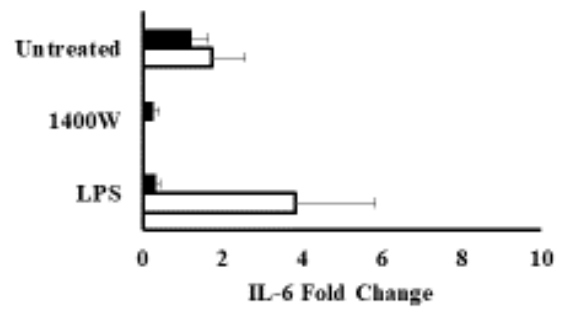

Figure 2.3: iNOS inhibition in PBMC

PBMC derived from STC and SUF sheep were isolated from whole blood and cultured with 1400W (N-(3- [Aminomethyl]benzyl)acetamidine)- iNOS inhibitor for two hours, before adding LPS to culture. Cells were cultured for 3 hours with LPS at $37^{\circ} \mathrm{C}$ and $5 \% \mathrm{CO}_{2}$ then gene expression was measured. Fold change was calculated using the $\Delta$ ct relative to housekeeping gene GAPDH and $2^{-\Delta \Delta C T}$ relative to cells culture in complete media (untreated) or cells treated with inhibitors were relative to DMSO treated cells. Error bars represent SEM. Each treatment was performed in triplicate. Significance was accepted at $\mathrm{P}<0.05$. * $\mathrm{P}<0.05$, *** $\mathrm{P}<0.001$. 
A.

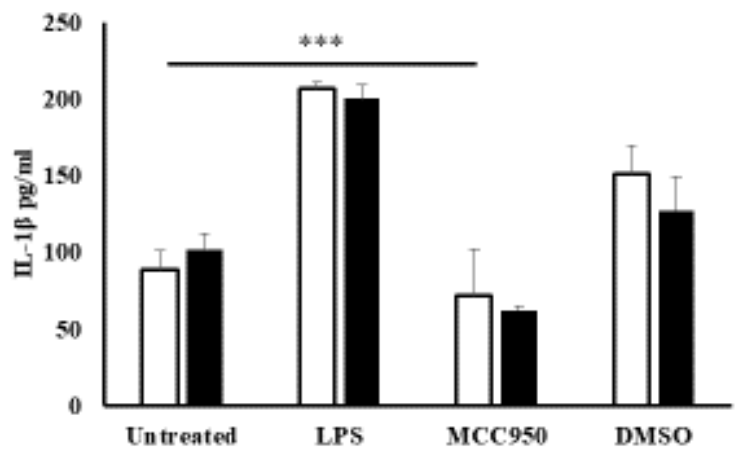

B.

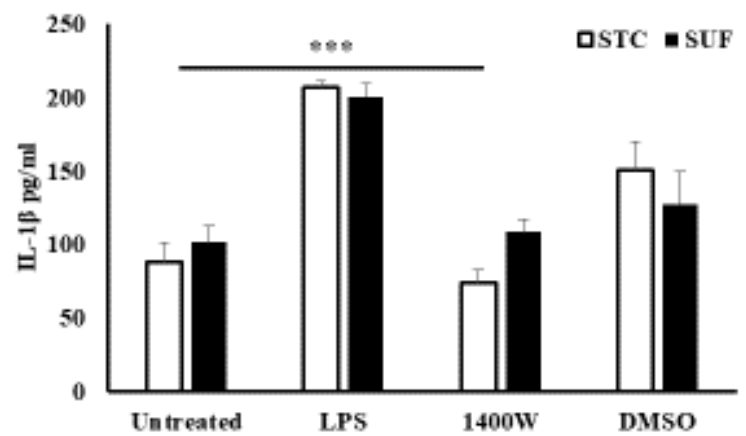

Figure 2.4: Pharmacological inhibition of NLRP3 and iNOS

PBMC derived from St. Croix (STC) and Suffolk (SUF) sheep were isolated from whole blood and cultured with $100 \mathrm{~nm}$ MCC950- NLRP3 inhibitor or 1400W-iNOS inhibitor for 2 hours prior to 3-hour LPS antigen culture. (A) PBMC were treated with $100 \mathrm{~nm}$ MCC950. (B) PBMC were treated with $10 \mu \mathrm{g} / \mathrm{ml} 1400 \mathrm{~W}$. Each treatment was performed in triplicate. Error bars represent SEM. Significance was accepted at $\mathrm{P}<0.05$. $* * * \mathrm{P}<0.001$. 
A.

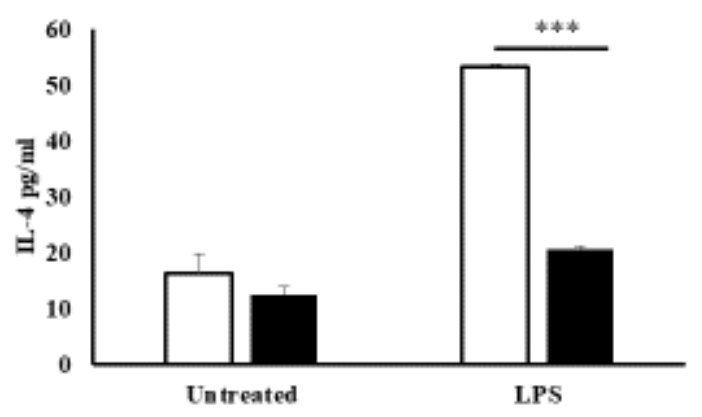

c.

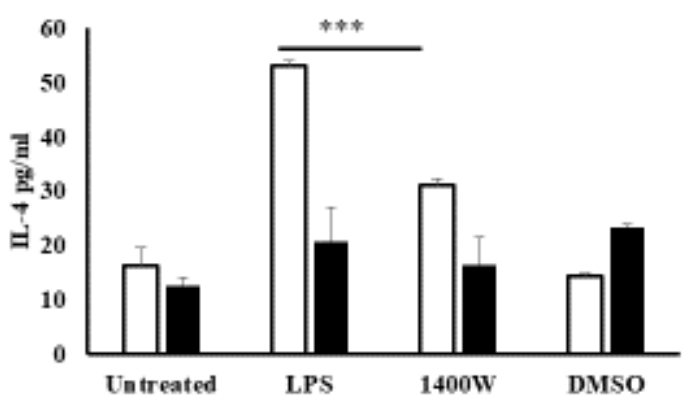

B.

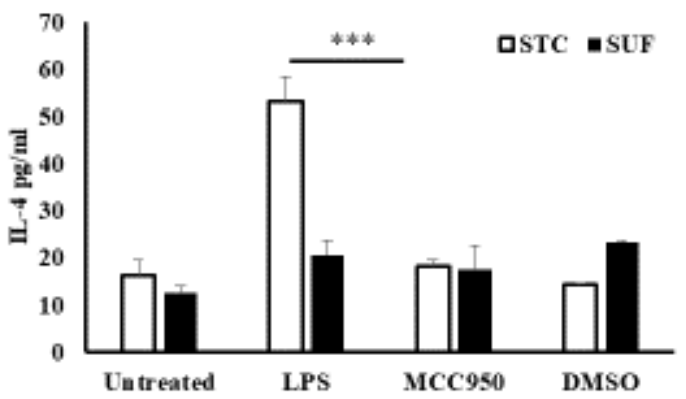

Figure 2.5: Quantification of IL-4 protein in cell culture supernatant after LPS stimulation PBMC derived from St. Croix (STC) and Suffolk (SUF) sheep were isolated from whole blood and cultured with CM (untreated) or $100 \mu \mathrm{g} / \mathrm{ml}$ of LPS, 0.3\% DMSO, $100 \mathrm{~nm}$ MCC950, or 10 $\mu \mathrm{g} / \mathrm{ml} 1400 \mathrm{~W}$. Following culture supernatant was collected and used to evaluate cellular IL-4 protein production. A) LPS stimulation, B) LPS stimulation with MCC950 pharmacological inhibitor, and C) LPS stimulation with the addition of $1400 \mathrm{~W}$. Each treatment was performed in triplicate. Error bars represent SEM. Significance was accepted at $\mathrm{P}<0.05$. $* * * \mathrm{P}<0.001$. 
A.

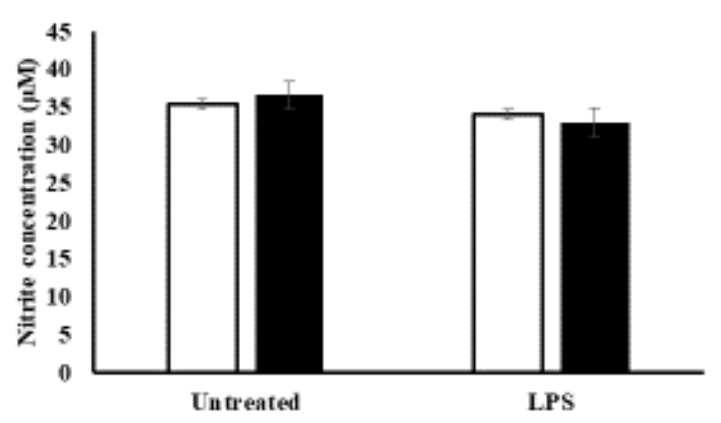

C.

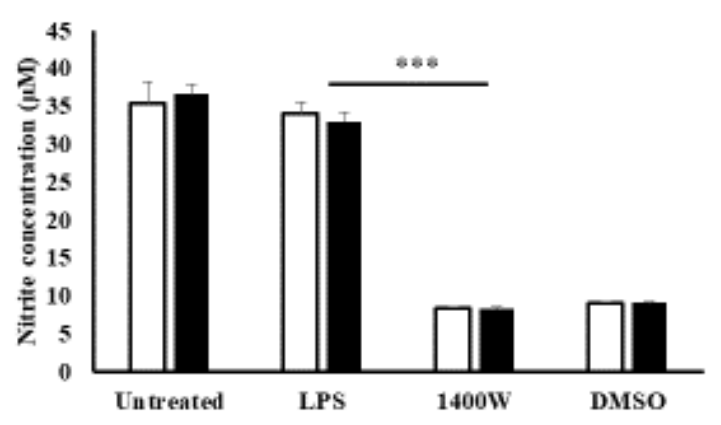

B.

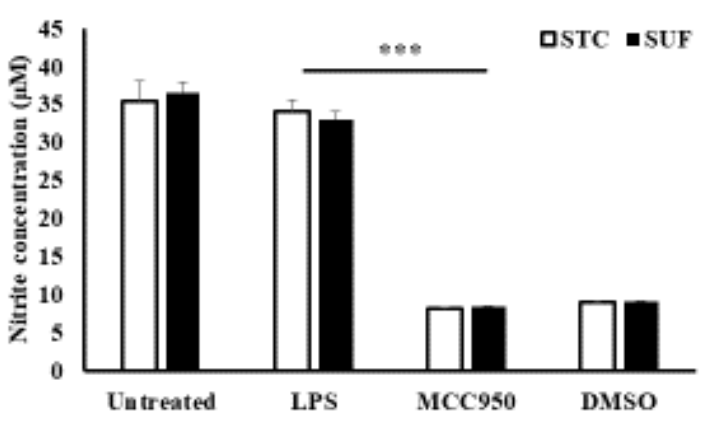

Figure 2.6: Nitrite concentrations in cell culture supernatant after stimulation with LPS PBMC derived from St. Croix (STC) and Suffolk (SUF) sheep were isolated from whole blood and cultured with CM (untreated) or $100 \mu \mathrm{g} / \mathrm{ml}$ of LPS (A), $100 \mathrm{~nm}$ MCC950 (B), or $10 \mu \mathrm{g} / \mathrm{ml}$ 1400W (C). Following culture supernatant was collected and nitrite concentrations were measured. Each treatment was performed in triplicate. Error bars represent SEM. Significance was accepted at $\mathrm{P}<0.05$. *** $\mathrm{P}<0.001$. 


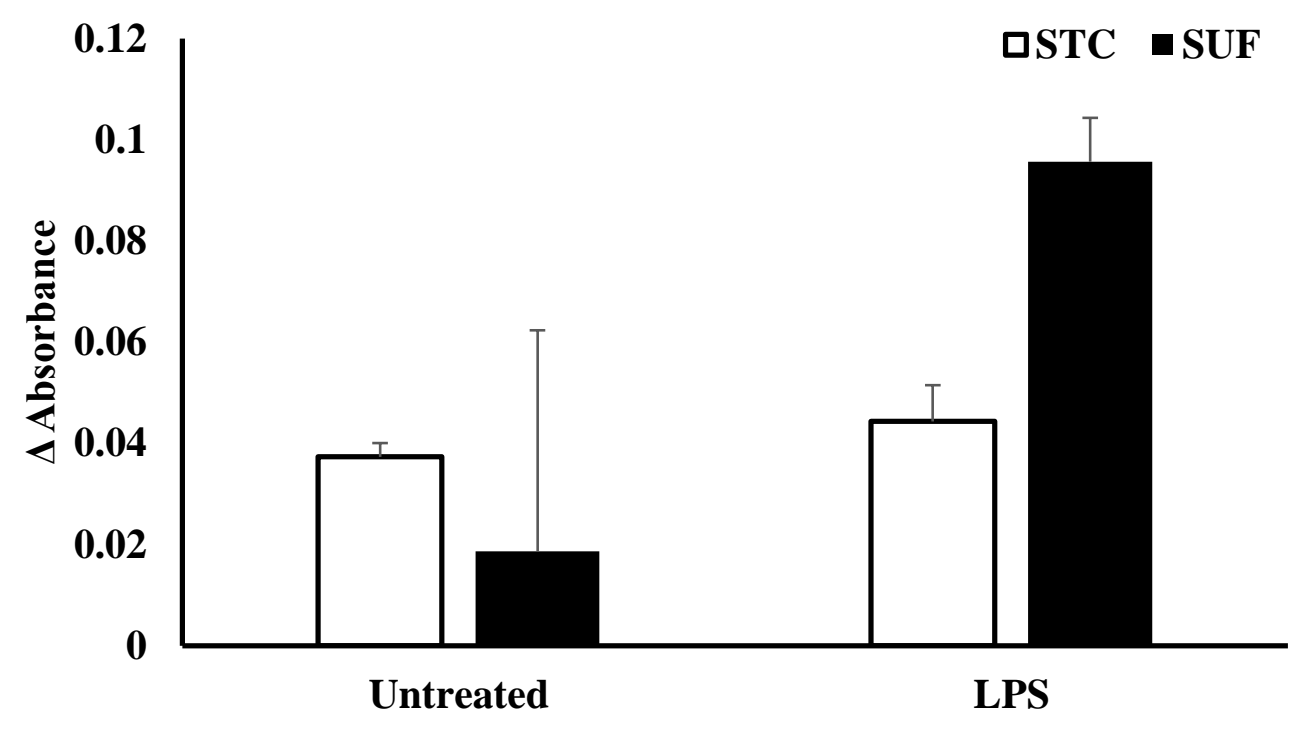

Figure 2.7: PBMC proliferation assay after LPS administration

PBMC derived from STC and SUF sheep were isolated from whole blood and cultured with 100 $\mu \mathrm{g} / \mathrm{ml}$ of LPS for $24 \mathrm{hrs}$. before alamar blue administration and then further cultured at $37^{\circ} \mathrm{C}$ and $5 \% \mathrm{CO}_{2}$ for an additional 48 hours before measuring absorbance at $570 \mathrm{~nm}$. Each treatment was run in triplicate. Error bars represent SEM. 
Table 2.1: qPCR primers for SYBR Green chemistry

\begin{tabular}{|c|c|c|c|}
\hline Gene Name & Abbreviation & Primer & Accession \# \\
\hline Glyceraldehyde3-phosphate & GAPDH & $\begin{array}{l}\text { F- CAGGAGCACGAGAGGAAGAG } \\
\text { R- AATGTATGGAGGTCGGGAGA }\end{array}$ & XM_004022179.1 \\
\hline Interleukin-6 & IL-6 & $\begin{array}{l}\text { F- TAACCACTCCAGCCACACAC } \\
\text { R- GATAACCTTTGCGTTCTTTACCC }\end{array}$ & EU293838 \\
\hline Tumor Necrosis Factor- $\alpha$ & $\mathrm{TNF} \alpha$ & $\begin{array}{l}\text { F- GGACCAGCCAAGAGAGAGAC } \\
\text { R- GCAGGGTGTATGAGAGAGCA }\end{array}$ & NM_001009471.1 \\
\hline Interferon- $\gamma$ & $\mathrm{IFN} \gamma$ & $\begin{array}{l}\text { F- ATGACGTGTCGCCAAAATC } \\
\text { R- GCAGGCAGGAGAACCATTAC }\end{array}$ & NM_001123004.1 \\
\hline Interleukin-12B & IL-12B & $\begin{array}{l}\text { F- ATTGAGGTCGTGATGGAAG } \\
\text { R- TGGTTTGATGATGTCCCTGA }\end{array}$ & NM_001009392.1 \\
\hline Toll-like receptor 2 & TLR2 & $\begin{array}{l}\text { F- CTCTTCCTGTTGCTCCTGCT } \\
\text { R- CTTCCTGGGCTTCCTCTTG }\end{array}$ & GQ221063.1 \\
\hline Toll-like receptor 4 & TLR4 & $\begin{array}{l}\text { F- GGCATCATCTTCATCGTCCT } \\
\text { R- CCACTCCAGGTAGGTGTTCC }\end{array}$ & НМ099914.1 \\
\hline $\begin{array}{l}\text { Nuclear factor kappa-light- } \\
\text { chain- enhancer of activated } \\
\text { B cells }\end{array}$ & $\mathrm{NF} \kappa \mathrm{B}$ & $\begin{array}{l}\text { F- ATTCAGCCCTTTGAACATCT } \\
\text { R- ATGGGATGTCAGTGGCGTTA }\end{array}$ & \\
\hline Interleukin-1 $\beta$ & IL-1 $\beta$ & $\begin{array}{l}\text { F- GAAGGGAAGGGAAGAACACC } \\
\text { R- ACGAATACAGGGGAGGCAGT }\end{array}$ & NM_001009251.1 \\
\hline Interleukin-10 & IL-10 & $\begin{array}{l}\text { F- TTTCCCTGACTGCCCTCTAA } \\
\text { R- GCTCCCTGGTTTCTCTTCCT }\end{array}$ & \\
\hline
\end{tabular}




\section{Chapter 3: The role of NLRP3 signaling in host protective immune response to Haemonchus contortus infection}

\section{Abstract}

Immune activation in response to Haemonchus contortus parasite infection requires an elevation of IL-4 as a key component of the response. This phenomenon occurs during early $H$. contortus infection in parasite-resistant St. Croix (STC) sheep. Studies have reported early responses associated with increased cellular infiltration at the site of infection and increased Th2 associated cytokine production. Parasite susceptible Suffolk (SUF) sheep display delayed responses resulting in adverse symptoms. Studies have reported significant upregulation of NLRP3, TLR2, and TLR4 genes in STC PBMC following stimulation with H. contortus larval antigen (HcLA). Preliminary data has found distinct differences in NLRP3 protein of STC and SUF sheep. Components of the NLRP3 inflammasome complex have been implicated as transcription factors for Th2 immunity. Therefore, the objective of this study was to investigate the role of NLRP3 in the context of $H$. contortus infection in sheep. PBMC from STC and SUF sheep were isolated from whole blood and stimulated with HcLA $(20 \mu \mathrm{g} / \mathrm{ml})$ for 6 hours. Larval antigen stimulation of STC PBMC resulted in a significant increase in IL-1 $\beta$ expression $(\mathrm{P}<0.01)$. However, the use of pharmacological inhibitor MCC950 had no effect on transcript or protein IL4 production. However, the pharmacological inhibition of iNOS resulted in a significant reduction in IL-4 protein production in both SUF and STC sheep. These experiments highlight the requirement of inflammatory mediators for the development of IL-4 responses, resulting in the establishment of full host protection. 


\section{Introduction}

Haemonchus contortus infection is a source of immense economical loss in small ruminant production (USDA, 2001). Anthelmintic overuse has led to resistance in parasitic helminths and has prompted producers to explore alternative strategies to control haemonchosis (Howell et al., 2008). Utilization of sheep breeds resistant to gastrointestinal nematode (GIN) is one approach to controlling infection. Of the limited parasite-resistant breeds, St. Croix (STC) have a unique ability to clear $H$. contortus infection without anthelmintic treatment. Alternatively, Suffolk (SUF) sheep, while commercially favorable, fail to respond to larval stages, perpetuating adverse symptoms associated with helminth infection (Alba-Hurtado and Munoz-Guzman, 2013). Resistance can be considered immune-mediated, as immunosuppression of genetically resistant merino sheep with dexamethasone resulted in increased egg production and worm burden (Presson et al., 1988).

Specific immune responses to helminth infection can be best classified as T-helper type 2 (Th2) responses. Th2 immune activation to helminth larval stages reduce adult establishment and fecundity. Innate immune cell influx (eosinophils, mast cells, globule leukocytes), cytokine production (IL-4, IL-5, IL-13), and increased parasite-specific antibody (IgA, IgE) production are all implicated in parasite expulsion (Balic et al., 2000, Lacroux et al., 2006). The gastrointestinal environment during a Th2 response is characterized by increased luminal flow coupled with intestinal muscle contractility, and these responses are driven by IL-4 and IL-13 cytokines (Harris et al., 2011). Both IL-4 and IL-13 are hallmark cytokines of Th2 response, they both signal through IL-4R $\alpha$, and exhibit a vast array of functions in regulating inflammation (Iademarco et al., 1995, Wynn, 2003).

In the context of Haemonchus contortus infection in sheep, the St. Croix breed of sheep have developed a natural immunity to parasitic infections as portrayed by early rise in IL-4 (Jacobs et al., 2016), increased cellular infiltration into the abomasal tissue within the first 7 days of 
infection (Bowdridge et al., 2015), increased IL-13 expression in abomasal tissue contributing to the weep and sweep method (Mackinnon et al., 2015), and reduction in larval and adult establishment (Bowdridge et al., 2015). Their natural immunity is a result of consistent exposure to parasitic challenge year-round as they originated in the Caribbean. Suffolk breed of sheep originated in the United Kingdom, in which results in limited parasite exposure. Consequences include delayed responses to parasite challenge leading to larval establishment, adult fecundity, reduction in host performance and pathologies associated with disease. RNA sequencing analysis of PBMC-derived from STC and SUF sheep cultured with HcLA revealed an upregulation in inflammatory associated genes, namely TLR2, TLR4, and NLRP3; and none were found to be upregulated in SUF PBMC (Jacobs et al., 2020).

RNA-sequencing from PBMC-derived from STC and SUF sheep were used to predict NLRP3 protein structure. When comparing the NLRP3 protein structures between STC and SUF sheep the predicted structures revealed vast differences. Nod like receptor family, pyrin domaincontaining 3 (NLRP3) is a cytoplasmic pattern recognition receptor found in its inactive monomeric form (Harton et al., 2002). Activation of NLRP3 by agonists such as, ATP, potassium efflux, pattern associated molecular patterns (PAMPs), danger associated molecular patterns (DAMPs), microbial products, viral products, particulate matter can lead to the formation of the NLRP3 inflammasome (Inohara et al., 2001). The inflammasome is comprised of the oligomerization of seven NLRP3 monomers (Inohara et al., 2001). NLRP3 protein complex amplifies the host immune response, can elicit cell pyroptosis, and leads to the secretion of the mature form of IL-18 and IL-1 $\beta$ (Martinon et al.,).

Classically, NLRP3 inflammasome has been shown to be involved in the induction of proinflammatory responses and dysregulation associated with disease progression. Little is known 
about the role of NLRP3 in Th2 responses. During Nippostrongylus brasiliensis infection NLRP3 protein, independent of the inflammasome complex has shown a major effect on neutrophil recruitment, assisting in both larval killing and reduction in tissue damage (Chenery et al., 2019). Development of full host protective immune responses to elicit $H$. contortus parasite expulsion is widely carried out by the incorporation of cellular recruitment, antibody production, and cytokine secretion, all largely under the Th2 arm of immune responses. These experiments work to expand the knowledge of the role of NLRP3 in Th2 responses, studies work to investigate the consequences of NLRP3 signaling during $H$. contortus infection in sheep, and to examine the relationship between IL- 4 and IL-1 $\beta$ protein. These data could aid in future therapies to assist in the development of full host protective immune responses in parasite-susceptible breeds of sheep.

\section{Materials and methods}

\section{Experimental Design}

St. Croix (STC) $(n=3)$ and Suffolk (SUF) sheep $(n=3)$ were raised under parasite-free conditions at the West Virginia University Animal Science Farm to allow for controlled and monitored infection. Animals in this study were not exposed to H. contortus infection prior to experimental inoculation. Four weeks after weaning, animals received a single oral dose of 10,000 H. contortus infective stage larvae (L3). Infection persisted for six weeks before animals were dewormed using levamisole $(8 \mathrm{mg} / \mathrm{kg})$ and rested for three weeks. To create an experimental model that mimics a natural pasture infection, where animals are consistently exposed to $L 3$, lambs were challenged infected. Following the rest period, lambs were challenged with an additional dose of 10,000 L3 which persisted for six weeks. Fecal egg count (FEC) and packed cell volume (PCV) were performed weekly throughout primary and challenge infection to monitor infection. At the time of experimentation lambs were primed, but not under active infection. 


\section{Haemonchus contortus larval culture}

Feces were collected from $H$. contortus-infected SUF wethers, used solely for the purpose of growing and collecting infective stage larvae. Feces were mixed with sterilized peat moss and activated charcoal and incubated for 7 days at $30^{\circ} \mathrm{C}$. Larvae were isolated using a Baermann apparatus (Zajac and Conboy, 2006) and stored in phosphate buffered saline (PBS) (pH 7.4) at $4^{\circ}$ C for no longer than 3 months before use. Larvae were diluted to a concentration of $1000 \mathrm{~L} 3 / \mathrm{mL}$ in sterile PBS before use.

\section{Crude Larval Antigen (HcLA)}

Infective stage L3 were removed from feces and collected into a $15 \mathrm{ml}$ tube with PBS (pH 7.4). Content was centrifuged for $5 \mathrm{~min}$ at $400 \mathrm{x} \mathrm{g}$ at $4^{\circ} \mathrm{C}$. Supernatant was discarded and $2 \mathrm{ml}$ of cold PBS was added to the pellet. The pellet was homogenized using a Dounce homogenizer while on ice until the majority of the larvae were broken up. Lysate was centrifuged at $15,000 \times \mathrm{g}$ at $4^{\circ}$ $\mathrm{C}$ for $1 \mathrm{~h}$. Supernatant was removed and passed through a $0.22 \mu \mathrm{m}$ syringe filter for sterilization. Protein concentration was determined using Pierce Rapid Gold BCA Protein Assay kit (Thermo Fisher scientific, Waltham, MA). Protease inhibitor cocktail (Sigma Aldrich, St. Louis, MO) was added at $1 \mu \mathrm{l}$ of cocktail per $\mu \mathrm{g}$ of protein. Crude larval antigen was aliquoted into $1.5 \mathrm{ml}$ centrifuge tubes and stored at $-80^{\circ} \mathrm{C}$ until further use.

\section{Crude worm antigen (HcWA)}

Adult $H$. contortus worms were extracted from the abomasum of euthanized sheep and placed in chilled PBS ( $\mathrm{pH}$ 7.4). The worms, in PBS, were homogenized using a dounce homogenizer on ice. Lysate centrifuged at $15,000 \mathrm{xg}$ at $4^{\circ} \mathrm{C}$ for $1 \mathrm{~h}$. Supernatant was removed and run through a $0.22 \mu \mathrm{m}$ syringe filter for sterilization. Protein concentration was determined using miro-BCA assay (Pierce, Rockford, IL). Protease inhibitor cocktail (Sigma Aldrich, St. Louis, MO) was added at $1 \mu \mathrm{l}$ of cocktail per $\mu \mathrm{g}$ of protein. Crude worm antigen was aliquoted into $1.5 \mathrm{ml}$ centrifuge tubes and stored at $-80^{\circ} \mathrm{C}$ until further use. 


\section{Peripheral Blood Mononuclear Cell (PBMC)}

Whole blood samples were collected via jugular venipuncture into ( $\mathrm{n}=3$ tubes/breed) 10 ml EDTA treated vacutainer tubes (Patterson vet, Saint Paul, MN). Peripheral blood mononuclear cell isolation was performed by centrifugation of blood samples at $400 \mathrm{xg}$ for $20 \mathrm{~min}$ at room temperature. Buffy coats were collected into a 15-ml sterile centrifuge tube suspended in 1-ml of sterile PBS (pH 7.4). Red blood cells were removed using ACK lysis buffer (Lonza, Walkersville, MD), and the resulting pellet was layered over sterile lymphocyte separation media (LSM) (Fisher Scientific, Hampton, $\mathrm{NH}$ ) and centrifuged at $400 \mathrm{x} g$ for 20 minutes at room temperature. Peripheral blood mononuclear cells were isolated and counted using TC-20 automated cell counter (Bio-RAD, Hercules, CA). Cells were diluted to a concentration of $1 \times 10^{6}$ cells $/ \mathrm{ml}$ for use in culture and suspended in complete media containing RPMI-1640 with 2 mmol/L L-glutamine, 10 $\%$ fetal bovine serum (FBS), and Penicillin- Streptomycin antibiotic.

\section{RNA and cDNA preparation}

Peripheral blood mononuclear cells were plated in a sterile 24-well cell culture plate (Greiner bio-one, Monroe, NC) at 500,000 cells per well and incubated with antigen treatment for 6 hours at $37^{\circ} \mathrm{C}$ and $5 \% \mathrm{CO}_{2}$. Treatments consisted of HcLA (20 $\left.\mu \mathrm{g} / \mathrm{ml}\right)$, and HcLA and MCC950NLRP3 inhibitor (100 nm) (Invivogen, San Diego, CA). Treatments were run in triplicate. Following incubation, total RNA was isolated from antigen stimulated PBMC using Direct-zol RNA MiniPrep Plus (Zymo Research, Irvine, CA).

Briefly, cells were lysed in $300 \mu \mathrm{l}$ of RNA-Bee reagent. Lysate was filtered through a Zymo-spin column, DNA was digested using DNase. RNA was washed and dried on a silica membrane, then eluted into RNase-free water. Samples were read on a BioTek plate reader (BioTek, Winooski, Vermont) measuring concentration and 260:280 for quality. Synthesis of cDNA was prepared using qScript XLT cDNA Supermix (Quantabio, Beverly, MA). Reactions 
were prepared in a 96 well PCR plate (VWR, Radnor, PA) by combining $4 \mu 1$ of 5X qScript XLT cDNA Supermix, $6 \mu$ l of nuclease-free water, and $10 \mu 1$ of RNA template per well. The plate was then placed in T100 thermal cycler (Bio-Rad, Hercules, CA) with conditions at $25^{\circ} \mathrm{C}$ for $5 \mathrm{~min}$, $42^{\circ} \mathrm{C}$ for $60 \mathrm{~min}$, and $85^{\circ} \mathrm{C}$ for $5 \mathrm{~min}$.

\section{Gene Expression}

\section{TaqMan Assays}

For qPCR, samples were made up of $10 \mu 12 \mathrm{X}$ TaqMan Gene Expression Master Mix (Applied Biosystems, Foster City, CA), $1 \mu \mathrm{l}$ of 20X TaqMan Gene Expression Assay (Glyceraldehyde 3-phosphate (GAPDH) - Bt03210913_g1 and Interleukin-4 (IL-4) Oa04927178_s1) (Applied Biosystems, Foster City, CA), $5 \mu 1$ of nuclease-free water, and $4 \mu 1$ (100 ng) cDNA template. Samples were analyzed in triplicate using CFX96 system (Bio-Rad, Hercules, CA). Conditions of qPCR were performed using the following thermal-cycler profile: 10-minute hold at $95^{\circ} \mathrm{C}$, then 40 cycles of 15 seconds at $95^{\circ} \mathrm{C}$ denaturation and 1-minute at $60^{\circ} \mathrm{C}$ extension. The reference gene used for normalization was Glyceraldehyde 3- phosphate dehydrogenase (GAPDH).

\section{SYBR Green}

qPCR reactions were run in triplicate with a Bio-Rad CFX96 system. Reaction conditions were: $50^{\circ} \mathrm{C}$ for 10 minutes and an initial denaturation at $95^{\circ} \mathrm{C}$ for 10 minutes followed by 40 cycles of denaturation at $95^{\circ} \mathrm{C}$ for 15 seconds, annealing for 30 seconds at $60^{\circ} \mathrm{C}$, and extension for $30 \mathrm{sec}$ at $72^{\circ} \mathrm{C}$. The PCR amplifications were carried out in a total volume of $20 \mu$, containing $10 \mu 1$ X Maxima SYBR Green qPCR master mix (Thermo Fisher Scientific, Waltham, MA), 1.2 $\mu \mathrm{l}$ of each forward and reverse primers (IDT, Morrisville, NC), $2.6 \mu \mathrm{l}$ of nuclease-free water, and $5 \mu l$ of cDNA template.

The relative fold change in gene expression of candidate genes were done using the $2^{-\Delta \Delta C T}$ method (Livak and Schmittgen, 2001). The obtained Ct values were used to calculate $\Delta \mathrm{Ct}$ values 
for genes of interest [Ct (test) - Ct (reference)]. The reference gene used for normalization was GADPH. Graphical representation for each gene was based on fold change over complete media control treated groups. Primers were previously verified for equal efficiency in amplification.

\section{Interleukin-1 $\beta$ ELISA}

Interleukin-1 $\beta$ protein was measured in culture supernatant following incubation of ovine PBMC with antigen treatment using an ovine specific IL-1 $\beta$ ELISA kit (MyBioSource, San Diego, CA, USA). Peripheral blood mononuclear cells were plated in a sterile 24-well cell culture plate (Greiner bio-one, Monroe, NC) at 500,000 cells per well and incubated with antigen treatment for 6 hours at $37^{\circ} \mathrm{C}$ and $5 \% \mathrm{CO}_{2}$. Treatments consisted of HcLA $(20 \mu \mathrm{g} / \mathrm{ml})$, HcLA with $1400 \mathrm{~W}(\mathrm{~N}-$ (3- [Aminomethyl]benzyl)acetamidine) (Sigma-Aldrich, St. Louis, MO) at $10 \mu \mathrm{g} / \mathrm{ml}$, and HcLA and MCC950- NLRP3 inhibitor (100 nm) (Invivogen, San Diego, CA). For inhibitor treated groups, cells were stimulated with pharmacological inhibitors for 2 hours prior to HcLA stimulation. Treatments were run in triplicate. Following incubation, cellular supernatant was collected into microcentrifuge tubes, $10 \mu \mathrm{l}$ of sample supernatant was added to the ovine specific IL-1 $\beta$ ELISA plate with $40 \mu$ of sample diluent and incubated for an hour. The process was carried out according to manufacturer's protocol. Samples were read at $450 \mathrm{~nm}$ and a standard curve was generated to detect IL-1 $(0$ to $600 \mathrm{pg} / \mathrm{ml}$ range).

\section{Interleukin-4 ELISA}

Concentration of IL-4 protein were detected in culture supernatant using ovine specific ELISA kits (MyBioSource, San Diego, CA, USA) Peripheral blood mononuclear cells were plated in a sterile 24-well cell culture plate (Greiner bio-one, Monroe, NC) at 500,000 cells per well and incubated with antigen treatment for 6 hours at $37^{\circ} \mathrm{C}$ and $5 \% \mathrm{CO}_{2}$. Treatments consisted HcLA (20 $\mu \mathrm{g} / \mathrm{ml})$, HcLA with 1400W (N-(3- [Aminomethyl]benzyl)acetamidine) (Sigma-Aldrich, St. Louis, MO) at $10 \mu \mathrm{g} / \mathrm{ml}$, and HcLA and MCC950- NLRP3 inhibitor (100 nm) (Invivogen, San Diego, 
CA). For inhibitor treated groups, cells were stimulated with pharmacological inhibitors for 2 hours prior to HcLA stimulation. Treatments were performed in triplicate. Following incubation, cellular supernatant was collected into microcentrifuge tubes, $100 \mu \mathrm{l}$ of sample supernatant was added to the ovine specific IL-4 ELISA plate and incubated for an hour. The process was carried out according to manufacturer's protocol. Samples were read at $450 \mathrm{~nm}$ and a standard curve was generated to detect IL-4 (6.25 to $400 \mathrm{pg} / \mathrm{mL}$ range).

\section{NLRP3 activation}

Peripheral blood mononuclear cells were plated in a sterile 24-well cell culture plate (Greiner bio-one, Monroe, NC) at $1 \times 10^{6}$ cells per well and incubated with antigen treatment for 6 hours at $37^{\circ} \mathrm{C}$ and $5 \% \mathrm{CO}_{2}$. Treatments consisted of HcLA $(20 \mu \mathrm{g} / \mathrm{ml}$ ), $5 \mathrm{mM} / \mathrm{ml}$ ATP (SigmaAldrich, St. Louis, MO), $20 \mu \mathrm{g} / \mathrm{ml} \mathrm{HcLA,} 20 \mu \mathrm{g} / \mathrm{ml} \mathrm{HcWA}$, and $25 \mu \mathrm{g} / \mathrm{ml}$ Poly I:C (InvivoGen, San Diego, CA). Treatments were run in triplicate. Supernatant was collected at the conclusion of cell culture and ovine specific ELISAs were used to measure IL-4, IL-17A, and IL-1 $\beta$ protein presence.

\section{Nitric Oxide assay}

Nitric oxide free radical was measured in sample supernatant by measuring the concentration of nitrite in cellular supernatant using the Griess Reagent System kit (Promega, Madison, WI). Peripheral blood mononuclear cells were plated in a sterile 24-well cell culture plate (Greiner bio-one, Monroe, NC) at 500,000 cells per well and incubated with antigen treatment for 6 hours at $37^{\circ} \mathrm{C}$ and $5 \% \mathrm{CO}_{2}$. Treatments consisted HcLA $(20 \mu \mathrm{g} / \mathrm{ml})$, HcLA with 1400W (N-(3- [Aminomethyl]benzyl)acetamidine) (Sigma-Aldrich, St. Louis, MO) at $10 \mu \mathrm{g} / \mathrm{ml}$, and HcLA and MCC950- NLRP3 inhibitor (100 nm) (Invivogen, San Diego, CA). For inhibitor treated groups, cells were stimulated with pharmacological inhibitors for 2 hours prior to HcLA stimulation. Treatments were run in triplicate. Following incubation, cellular supernatant was 
collected into microcentrifuge tubes, $50 \mu \mathrm{l}$ of sample supernatant was added to a 96 -well cell culture plate. The process was carried out according to manufacturer's protocol. Samples were read at $540 \mathrm{~nm}$ and a standard curve was generated to detect nitrite ( 0 to $100 \mu \mathrm{M}$ range).

\section{Statistics}

Sigma Plot software version 14.5 was used for statistical analysis. Statistical analysis for qPCR data was based on fold change values, results were normalized to both control group and GAPDH and reported as fold change. A two-way ANOVA with fixed effects of breed and treatment was used to assess breed differences in response to HcLA stimulation or the incorporation pharmacological inhibitors MCC950 and 1400W to culture. The Holm-sidak post hoc test was utilized for means comparison. A two-way ANOVA with fixed effects of breed and treatment was used to assess protein assays. The Holm-Sidak post hoc test was used for means comparison. Differences were considered significant if $\mathrm{P}<0.05$ for all experiments.

\section{Results}

\section{Gene expression analysis of PBMC after 6-hour culture}

Peripheral blood mononuclear cells were cultured with $20 \mu \mathrm{g} / \mathrm{ml}$ of HcLA for 6 hours before gene expression analysis. Within both breeds a significant down regulation was observed in the expression of GATA3 $(\mathrm{P}<0.05)$ (figure 3.1B), TBET $(\mathrm{P}<0.01)$ (figure 3.1F), TLR2 $(\mathrm{P}<$ 0.05) (figure $3.1 \mathrm{G}$ ), and TLR4 ( $\mathrm{P}<0.001$ ) (figure 3.1H). HcLA stimulation significantly upregulated FOXP3 ( $\mathrm{P}<0.01)$ (figure 3.1D) in SUF PBMC and IL-1 $\beta(\mathrm{P}<0.001)$ (figure 3.1I) in STC PBMC.

Inhibition of NLRP3 inflammasome activation in SUF PBMC resulted in a significant increase in the expression of STAT6 (P < 0.001) (figure 3.3A), IL-10 ( $<0.001$ ) (figure 3.3C), TLR2 ( $\mathrm{P}<0.001$ ) (figure 3.3D), and TLR4 ( $\mathrm{P}$ < 0.001) (figure 3.3E). While the pharmacological 
inhibition of NLRP3 inflammasome in STC PBMC resulted in a significant increase in the expression of IL-1 $(\mathrm{P}<0.001)$ (figure 3.3F).

\section{NLRP3 inflammasome activation}

To assess the capability of $H$. contortus antigen to act as an agonist for NLRP3 inflammasome activation, PBMC were isolated and cultured with HcLA, HcWA (H. contortus worm antigen), and known activators of NLRP3 inflammasome activation for comparison. Inflammasome activation was measured by the presence of IL-1 $\beta$ in cell culture supernatant. When measuring IL-1 $\beta$ protein concentrations in cellular supernatant, there were no breed differences observed however, there was a treatment effect in which PBMC from both breeds produced significantly greater amounts of IL- $1 \beta$ protein in response to stimulation with ATP as compared to stimulation with Poly I:C $(\mathrm{P}<0.05)$ (figure 3.2A). To observe the relationship between IL-4 production and NLRP3 inflammasome activation, IL-4 protein was measured in cell culture supernatant. STC PBMC produced significantly greater amounts of IL-4 protein after stimulation with LPS and HcLA, as compared to SUF PBMC (P < 0.001) (figure 3.2B).

\section{Protein concentration in cell culture supernatant}

PBMC from STC and SUF sheep were isolated from whole blood and stimulated with HcLA to observe IL-4 protein secretion in cellular supernatant. There was a significant increase in IL-4 protein measured in cellular supernatant of STC PBMC as compared to SUF PBMC (P < 0.001) (figure 3.4A). The incorporation of both MCC950 and $1400 \mathrm{~W}$ to cell culture resulted in a similar trend in a significant reduction in IL-4 protein measured in the cellular supernatant of STC PBMC (P < 0.001) (figure 3.4B, 3.4C). In measuring the production of IL-1 $\beta$ protein in cellular supernatant there were no significant differences observed in response to stimulation with HcLA (figure 3.5A), similarly no significant differences observed with the addition of MCC950 or 1400W to cell culture (figure 3.5B, 3.5C). Nitrite concentrations were measured in cell culture 
supernatant following culture with HcLA, MCC950, and 1400W stimulation. There were no breed differences observed in nitrite concentrations. However, there was a treatment effect on nitrite concentrations, PBMC from both breeds of sheep produced significantly less nitrite in response to stimulation with HcLA ( $<$ 0.001) (figure 3.6A). The incorporation of MCC950 or $1400 \mathrm{~W}$ to cell culture with HcLA displayed a similar trend with a significant reduction in nitrite concentrations $(\mathrm{P}<0.001)$ (figure 3.6B and 3.6C).

\section{Discussion}

Parasite-resistant STC sheep display the natural ability to respond early to parasite infection reducing the establishment of adults and adverse symptoms (Bowdridge et al., 2015). On the contrary parasite susceptible SUF sheep display a lag in response time to larval stages of $H$. contortus resulting in the establishment of adults and leading to adverse symptoms, reduction in animal performance, and in severe cases, death (Jacobs et al., 2016). RNA sequencing analysis of PBMC stimulated with HcLA revealed an upregulation in TLR2, TLR4, and NLRP3 immune regulation receptors (Jacobs et al., 2020). Our data suggest that the stimulation of STC and SUF PBMC with HcLA resulted in a downregulation in Th2 transcription factor (GATA3), Th1 transcription factor (TBET), and antigen recognition receptors (TLR2 and TLR4). The addition of HcLA stimulus to culture resulted in a difference of expression patterns, SUF PBMC had an upregulation in regulatory transcription factor FOXP3 expression, while STC PBMC had an upregulation in IL-1 $\beta$ expression. These data align with the literature in parasite excretory secretory proteins containing immunomodulatory factors that may upregulate host regulatory responses (Hewitson et al., 2009). Further investigation of peripheral T cell populations identified during $H$. contortus infection in STC and SUF sheep are necessary to identify if delays observed in SUF sheep are a result of increased regulatory $\mathrm{CD} 25^{+}$cells. 
The upregulation in IL-1 $\beta$ expression observed in STC PBMC from our data, along with the prior reports of significant upregulation in NLRP3 observed in STC PBMC stimulated with HcLA set our focus on NLRP3 inflammasomes role in $H$. contortus infection. To assess inflammasome activation we concentrated on its product of activation, IL-1 $\beta$ (Segovia et al., 2017). The activation of NLRP3 inflammasome can be achieved as a result of the stimulation by many agonists such as, ATP, PAMPs, DAMPs, microbial products, viral products, and particulate matter (Inohara \& Nunez et al., 2001). Our data provide evidence of NLRP3 activation in both STC and SUF PBMC after stimulation with both $H$. contortus larval and adult antigens. Due to the wide range of agonists capable of activating NLRP3 inflammasome, its classic activation requires a tightly regulated two-step process (Bauernfeind et al., 2019). The first step requires TLR priming to enhance NFאB signals and secondly the exposure NLRP3 protein to PAMPs and DAMPs for the construction of the inflammasome complex (Bauernfeind et al., 2019). Although NLRP3 has been classically studied in response to viral and microbial infections with the need for the amplification of host proinflammatory responses, literature has also revealed a role for NLRP3 proteins requirement in Th2 parasitic infections (Chenery et al., 2019).

Data from these studies reveal the inhibition of NLRP3 inflammasome activation in PBMC from parasite susceptible SUF sheep resulted in upregulation in TLR2, TLR4, STAT6, IL-4, and IL-10 genes. Further investigation on the potential for SUF dysfunctional NLRP3 being the cause of delayed responses are necessary, these data show the inhibition of SUF NLRP3 resulting in improved responses of antigen recognition and Th2 differentiation. However, when observing the effects of both pharmacological inhibitors MCC950 and 1400W on IL-4 protein production, STC PBMC resulted in a significant reduction in IL-4 measured in cellular supernatant. There will need to be further experiments to support these preliminary data on investigating a direct link between 
NLRP3 inflammasome activation and IL-4 production. The pharmacological inhibition of NLRP3 inflammasome with small molecule inhibitor MCC950 directly interacts with the Walker B motif within the NLPR3 NACHT domain, thereby, blocking ATP hydrolysis and inhibiting NLRP3 activation and inflammasome formation (Coll RC et al., 2015). Additional studies are necessary to investigate both the inhibition of NLRP3 protein alone independent of the inflammasome and the alternate routes of IL-1 $\beta$ secretion and their role in $H$. contortus infection.

Interleukin- $1 \beta$ is a potent proinflammatory factor secreted by innate immune cells in response to pathogenic challenge. The secretion route of IL- $1 \beta$ employs one or more nonconventional pathways of secretion. Routes of IL- $1 \beta$ secretion are dictated by the strength of the inflammatory stimuli. ATP-induced IL-1 $1 \beta$ release is disrupted in macrophages by the inhibition of caspase-1 knock out mice (Brough et al., 2003). The targeted inhibition of NLRP3 in T. muris infection induced amelioration of disease as shown by decreased Th1 cytokines, elevated Th2 cytokines, accelerated worm expulsion, and a decrease in immunopathology's associated with disease (Alhallaf et al., 2018). Preliminary data observed in our lab observing NLRP3 responses in PBMC derived from SUF and STC sheep in a classic model of LPS infection revealed the pharmacological inhibition of NLRP3 inflammasome to result in a significant reduction in IL-1 $\beta$ secretion, denotating a reduction in NLRP3 activation. In an alternative model of NLRP3 activation in response to HcLA stimulation in STC and SUF PBMC the pharmacological inhibition of NLRP3 had no effect on IL-1 $\beta$ production or IL-4.

These data are the first to observe IL- $1 \beta$ production in the context of $H$. contortus infection in sheep. On the transcript level the pharmacological inhibition of NLRP3 resulted in a reduction in IL-1 $\beta$ expression however, on the protein level there were no differences observed. These data highlight the potential for a non-conventional mechanism of IL-1 $\beta$ secretion under abnormal 
conditions. These preliminary data unfold the potential for further investigation into the consequences of the total inhibition of the NLRP3 inflammasome complex namely, the inhibition of caspase 1. Preliminary data from our lab has outlined distinct NLRP3 primary protein structural differences between STC and SUF sheep (data not published), further investigation will need to uncover the inhibition of both IL-1 $\beta$ and IL-18 protein production in the context of $H$. contortus parasitic infection. During L. major infection IL-18 production enhanced IL-4 expression by increasing GATA3 expression within $\mathrm{CD}^{+}$cells. Future investigation of NLRP3 inflammasome complex components acting as Th2 regulators of transcription are necessary. An understanding of this phenomenon may allow for the development of chemotherapeutics that would enhance early immune activation in economically relevant breeds of sheep.

\section{Literature cited}

1. Bauernfeind, F. G., Horvath, G., Stutz, A., Alnemri, E. S., MacDonald, K., Speert, D., Fernandes-Alnemri, T., Wu, J., Monks, B. G., Fitzgerald, K. A., Hornung, V., \& Latz, E. (2009). Cutting Edge: NF-кB Activating Pattern Recognition and Cytokine Receptors License NLRP3 Inflammasome Activation by Regulating NLRP3 Expression. The Journal of Immunology, 183(2), 787-791. https://doi.org/10.4049/jimmunol.0901363

2. Besier, R. B., Kahn, L. P., Sargison, N. D., \& Van Wyk, J. A. (2016). The Pathophysiology, Ecology and Epidemiology of Haemonchus contortus Infection in Small Ruminants. In Advances in Parasitology (Vol. 93, pp. 95-143). Elsevier. https://doi.org/10.1016/bs.apar.2016.02.022

3. Bruchard, M., Rebé, C., Derangère, V., Togbé, D., Ryffel, B., Boidot, R., Humblin, E., Hamman, A., Chalmin, F., Berger, H., Chevriaux, A., Limagne, E., Apetoh, L., Végran, F., \& Ghiringhelli, F. (2015). The receptor NLRP3 is a transcriptional regulator of TH2 differentiation. Nature Immunology, 16(8), 859-870. https://doi.org/10.1038/ni.3202 
4. Escribano, C., Saravia, A., Costa, M., Castells, D., Ciappesoni, G., Riet-Correa, F., \& Freire, T. (2019). Resistance to Haemonchus contortus in Corriedale sheep is associated to high parasite-specific IgA titer and a systemic Th2 immune response. Scientific Reports, 9(1), 19579. https://doi.org/10.1038/s41598-019-55447-6

5. Gibbs, H. C. (1982). Mechanisms of survival of nematode parasites with emphasis on hypobiosis. Veterinary Parasitology, 11(1), 25-48. https://doi.org/10.1016/03044017(82)90119-4

6. Gurung, P., Karki, R., Vogel, P., Watanabe, M., Bix, M., Lamkanfi, M., \& Kanneganti, T.-D. (2015). An NLRP3 inflammasome-triggered Th2-biased adaptive immune response promotes leishmaniasis. Journal of Clinical Investigation, 125(3), 1329-1338. https://doi.org/10.1172/JCI79526

7. Harton, J. A., Linhoff, M. W., Zhang, J., \& Ting, J. P.-Y. (2002). Cutting Edge: CATERPILLER: A Large Family of Mammalian Genes Containing CARD, Pyrin, Nucleotide-Binding, and Leucine-Rich Repeat Domains. The Journal of Immunology, 169(8), 4088-4093. https://doi.org/10.4049/jimmunol.169.8.4088

8. Inohara, N., \& Nuñez, G. (2001). The NOD: A signaling module that regulates apoptosis and host defense against pathogens. Oncogene, 20(44), 6473-6481. https://doi.org/10.1038/sj.onc. 1204787

9. Kaplan, M. H., Sun, Y.-L., Hoey, T., \& Grusby, M. J. (1996). Impaired IL-12 responses and enhanced development of Th2 cells in Stat4-deficient mice. Nature, 382(6587), 174177. https://doi.org/10.1038/382174a0

10. Kopf, M., Grost, G. L., Bachmann, M., Lamers, M. C., Bluethmann, H., \& KOhler, G. (1993). Disruption of the murine IL-4 gene blocks Th2 cytokine responses. 362, 4. 
11. Martinon, F., \& Burns, K. (n.d.). The Inflammasome: A Molecular Platform Triggering Activation of Inflammatory Caspases and Processing of proIL- ${ }^{\mathrm{N}}$. Molecular Cell, 10.

12. Middleton, D., Garza, J. J., Greiner, S. P., \& Bowdridge, S. A. (2020). Neutrophils rapidly produce Th2 cytokines in response to larval but not adult helminth antigen. Parasite Immunology, 42(1). https://doi.org/10.1111/pim.12679

13. O’Connor, L. J., Walkden-Brown, S. W., \& Kahn, L. P. (2006). Ecology of the freeliving stages of major trichostrongylid parasites of sheep. Veterinary Parasitology, 142(1-2), 1-15. https://doi.org/10.1016/j.vetpar.2006.08.035

14. Roberts, J. L., \& Swan, R. A. (1981). Quantitative studies of ovine haemonchosis. I. Relationship between faecal egg counts and total worm counts. Veterinary Parasitology, 8(2), 165-171. https://doi.org/10.1016/0304-4017(81)90044-3

15. Roberts, L. S., Schmidt, G. D., \& Janovy, J. (2009). Gerald D. Schmidt \& Larry S. Roberts'foundations of parasitology (8th ed). McGraw-Hill Higher Education.

16. Roeber, F., Jex, A. R., \& Gasser, R. B. (2013). Impact of gastrointestinal parasitic nematodes of sheep, and the role of advanced molecular tools for exploring epidemiology and drug resistance-An Australian perspective. Parasites \& Vectors, 6(1), 153. https://doi.org/10.1186/1756-3305-6-153

17. Scott, P., Natovitz, P., Coffman, R. L., Pearce, E., \& Sher, A. (1988). Immunoregulation of cutaneous leishmaniasis. T cell lines that transfer protective immunity or exacerbation belong to different $\mathrm{T}$ helper subsets and respond to distinct parasite antigens. The Journal of Experimental Medicine, 168(5), 1675-1684. https://doi.org/10.1084/jem.168.5.1675

18. Segovia, J. A., Chang, T.-H., Winter, V. T., Coalson, J. J., Cagle, M. P., Pandranki, L., Bose, S., Baseman, J. B., \& Kannan, T. R. (2017). NLRP3 Is a Critical Regulator of 
Inflammation and Innate Immune Cell Response during Mycoplasma pneumoniae Infection. Infection and Immunity, 86(1), e00548-17. https://doi.org/10.1128/IAI.0054817

19. Swain, S. L., Weinberg, A. D., English, M., \& Huston, G. (n.d.). IL-4 directs the development of Th2-like helper effectors. 12.

20. Van den Brom, R., Moll, L., Kappert, C., \& Vellema, P. (2015). Haemonchus contortus resistance to monepantel in sheep. Veterinary Parasitology, 209(3-4), 278-280. https://doi.org/10.1016/j.vetpar.2015.02.026 
A.

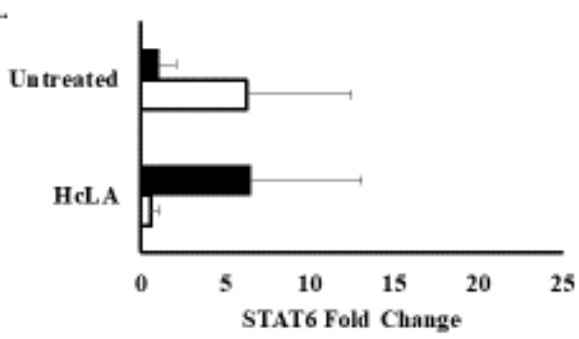

D.

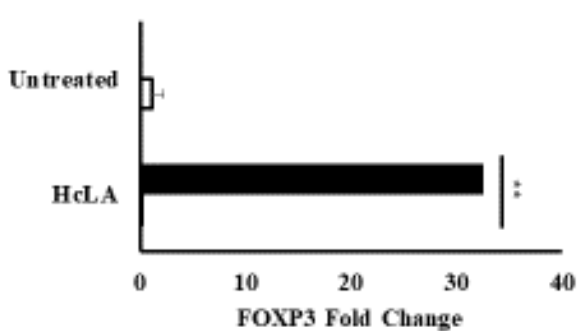

G.

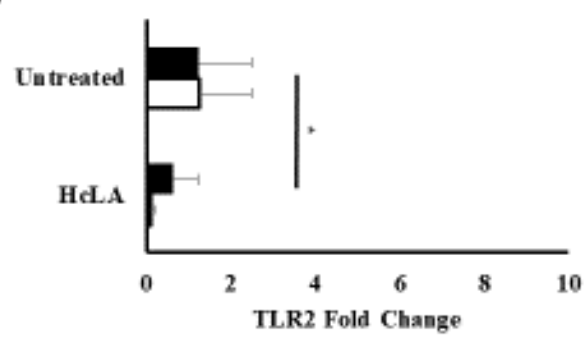

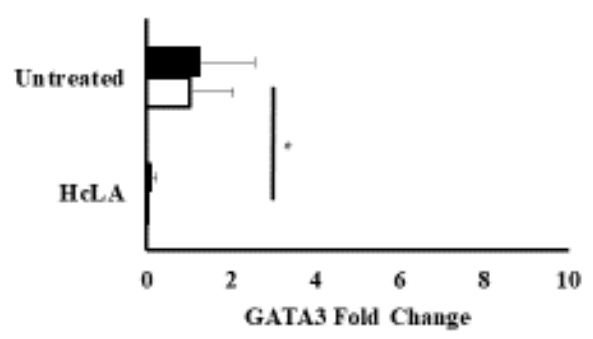

E.

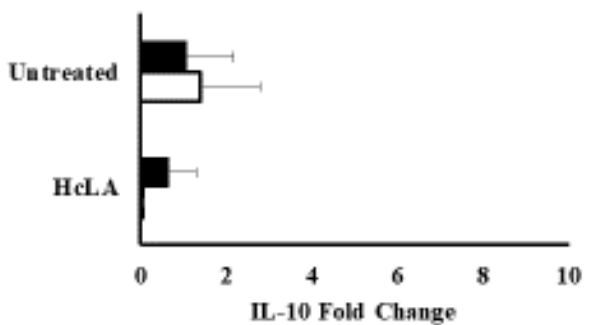

H.

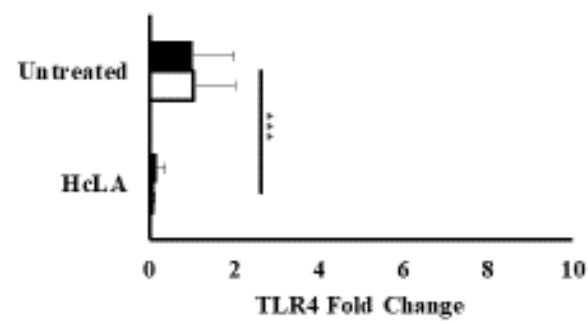

c.
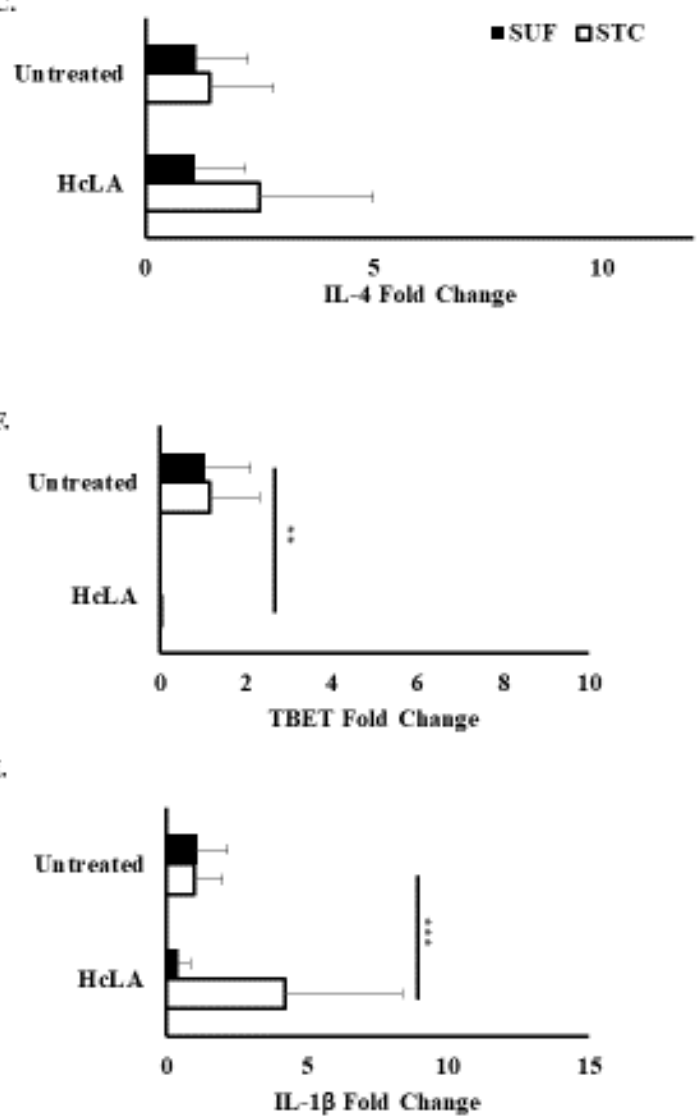

Figure 3.1: Gene expression analysis of PBMC after 6-hour culture with HcLA

PBMC-derived from STC and SUF sheep were isolated from whole blood and cultured at 500,000 cells/well with complete media (CM)- untreated or $20 \mu \mathrm{g} / \mathrm{ml}$ of $\mathrm{HcLA}$ at $37^{\circ} \mathrm{C}$ and $5 \% \mathrm{CO}_{2}$ for 6 hours, gene expression was measured. Fold change was calculated using the $\Delta$ ct relative to housekeeping gene GAPDH and $2^{-\Delta \Delta C T}$ relative to cells culture media. Error bars represent SEM. Significance was accepted at $\mathrm{P}<0.05$. $* \mathrm{P}<0.05$, ** $\mathrm{P}<0.01$, *** $\mathrm{P}<0.001$. 
A.

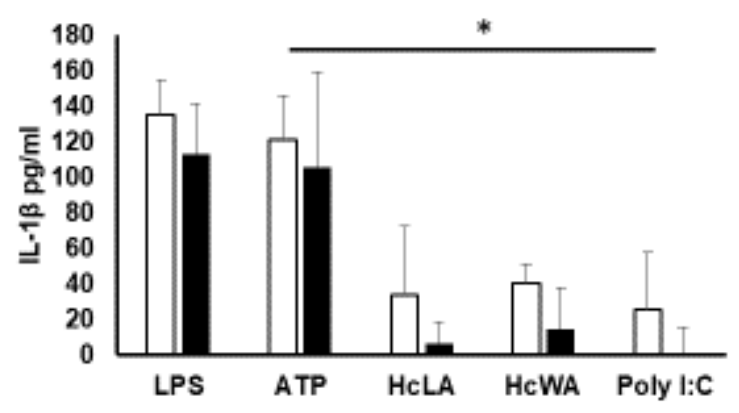

B.

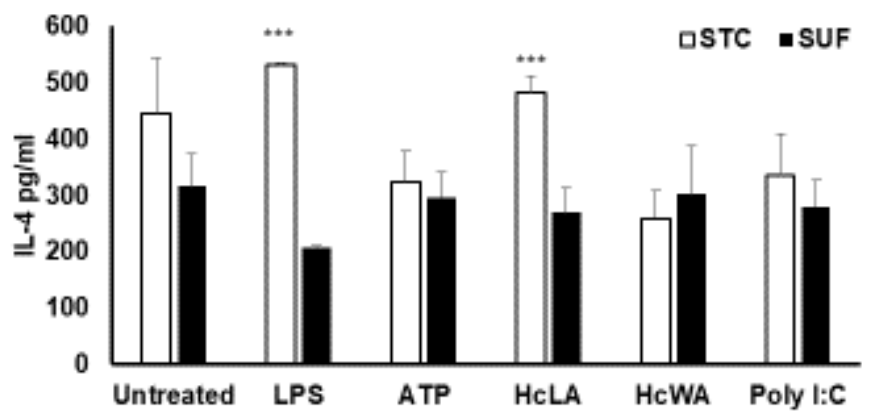

Figure 3.2: NLRP3 inflammasome activation

To assess NLRP3 activation in STC and SUF PBMC, cells were isolated from whole blood and plated at $1 \times 10^{6}$ cells/well. Cells were cultured with $5 \mathrm{mM}$ ATP, $20 \mu \mathrm{g} / \mathrm{ml} \mathrm{HcLA}, 20 \mu \mathrm{g} / \mathrm{ml} \mathrm{HcWA}$, $100 \mu \mathrm{g} / \mathrm{ml} \mathrm{LPS}, 25 \mu \mathrm{g} / \mathrm{ml}$ Poly I:C for 6 hours before cellular supernatant collection. A) measure of IL-1 $\beta$ protein B) measure of IL-4 protein. Each treatment was performed in triplicate. Error bars represent SEM. Significance was accepted at $\mathrm{P}<0.05$. $* \mathrm{P}<0.05$, $* * * \mathrm{P}<0.001$. 
A.

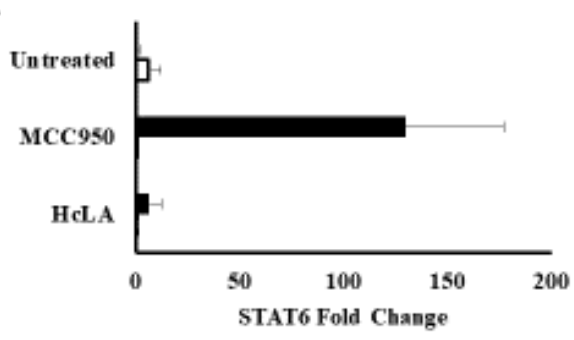

D.

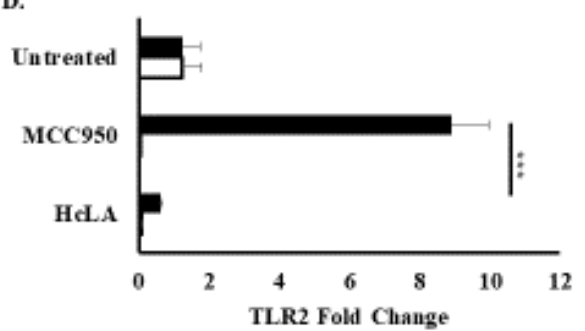

G.

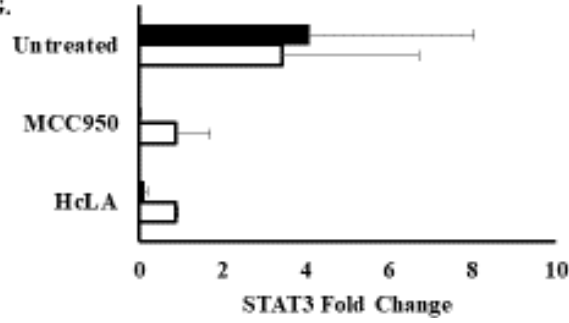

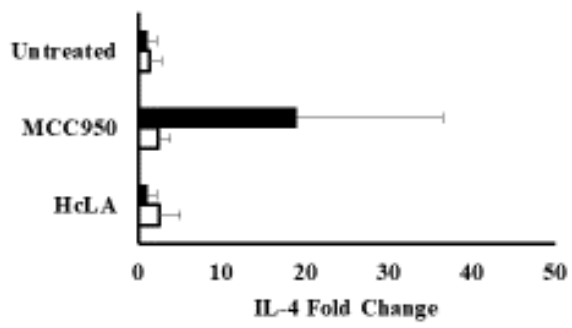

E.

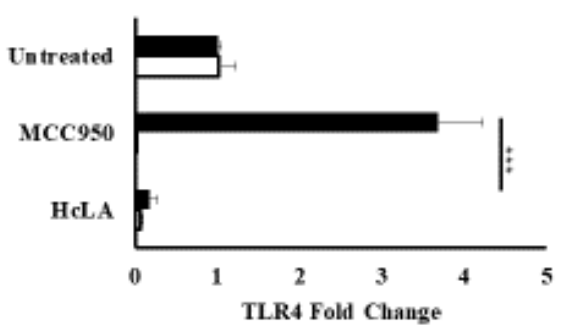

c.

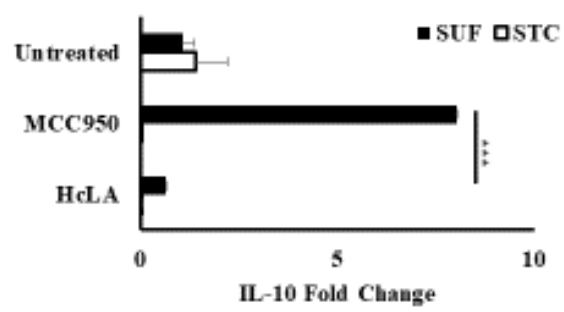

F.

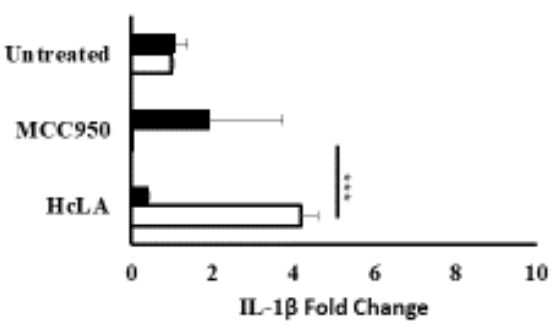

Figure 3.3: Inhibition of NLRP3 inflammasome activation in PBMC

PBMC derived from STC and SUF sheep were isolated from whole blood and cultured with 100 nm MCC950 sodium for two hours, before adding HcLA to culture. Cells were cultured for 6 hours with $\mathrm{HcLA}$ at $37^{\circ} \mathrm{C}$ and $5 \% \mathrm{CO}_{2}$ for then gene expression was measured. Fold change was calculated using the $\Delta$ ct relative to housekeeping gene GAPDH and $2^{-\Delta \Delta \mathrm{CT}}$ relative to cells culture media (untreated) or DMSO treated cells for inhibited groups. Error bars represent SEM. Significance was accepted at $\mathrm{P}<0.05$. *** $\mathrm{P}<0.001$. 
A.

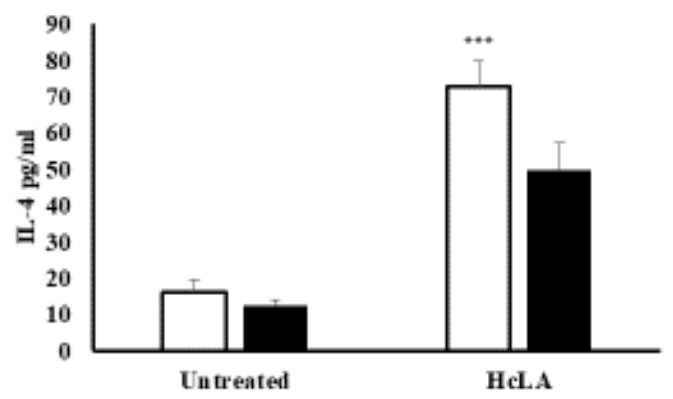

C.

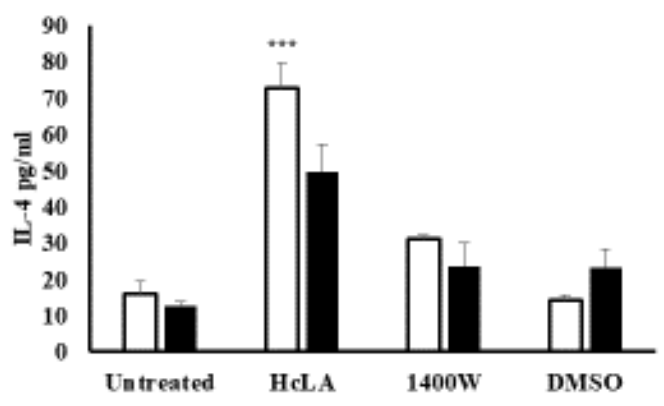

B.

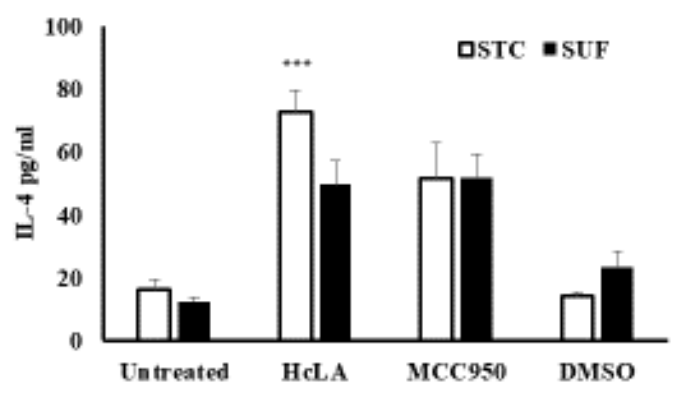

Figure 3.4: measure of IL-4 protein in cellular supernatant

PBMC derived from St. Croix (STC) and Suffolk (SUF) sheep were isolated from whole blood and cultured with CM (untreated) or $20 \mu \mathrm{g} / \mathrm{ml}$ of HcLA, 0.3\% DMSO, $100 \mathrm{~nm}$ MCC950, or 10 $\mu \mathrm{g} / \mathrm{ml} 1400 \mathrm{~W}$. A) HcLA culture, B) addition of $100 \mathrm{~nm}$ MCC950 to culture, C) addition of 1400W to culture. Following culture supernatant was collected and used to evaluate cellular IL-4 protein production. Each treatment was performed in triplicate. Error bars represent SEM. Significance was accepted at $\mathrm{P}<0.05$. $* * * \mathrm{P}<0.001$. 
A.

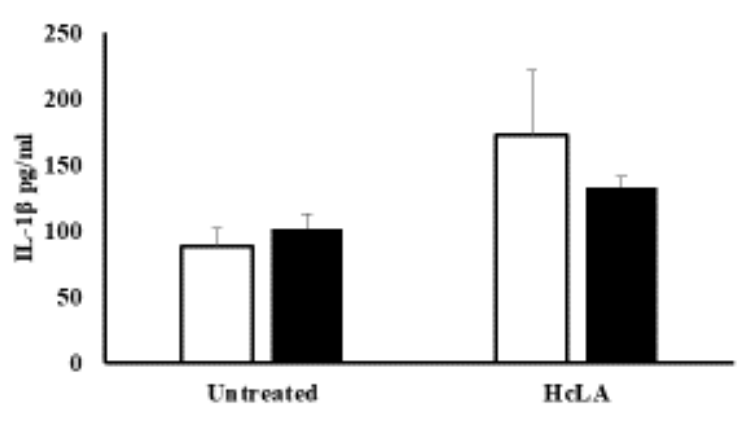

C.

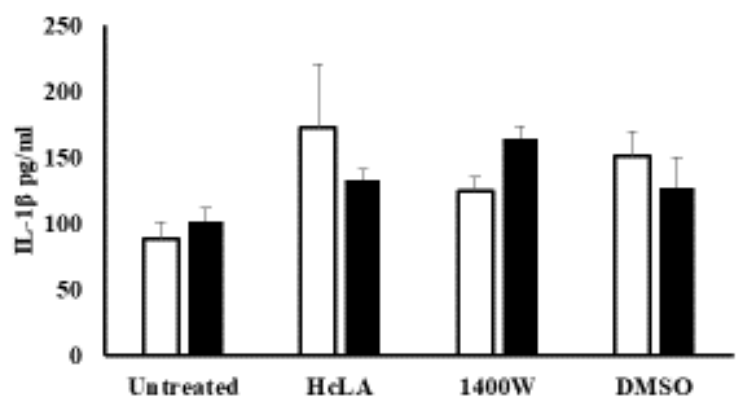

B.

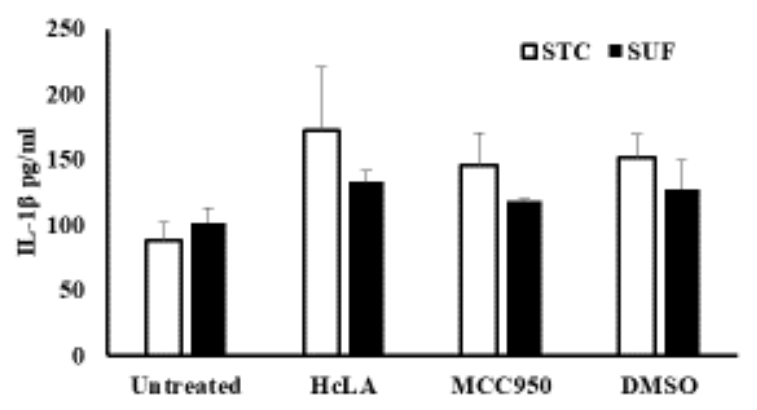

Figure 3.5: Measure of IL-1 $\beta$ protein in cellular supernatant

PBMC derived from St. Croix (STC) and Suffolk (SUF) sheep were isolated from whole blood and cultured with CM (untreated) or $20 \mu \mathrm{g} / \mathrm{ml}$ of HcLA for 6-hours. (A) $20 \mu \mathrm{g} / \mathrm{ml}$ of HcLA culture, (B) culture with HcLA and $100 \mathrm{~nm}$ MCC950, (C) culture with HcLA and 1400W. Each treatment was performed in triplicate. Error bars represent SEM. 
A.

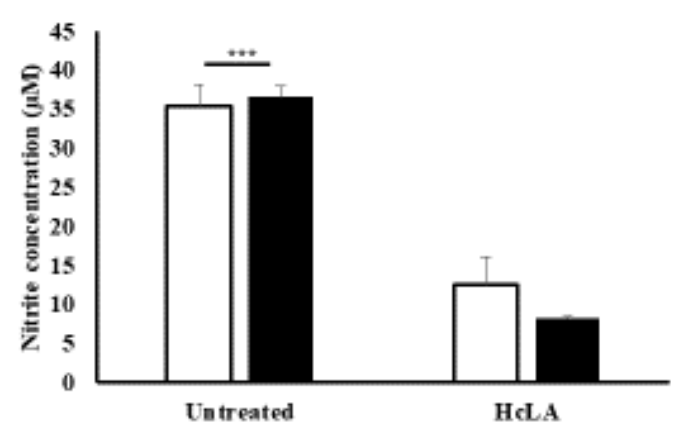

C.

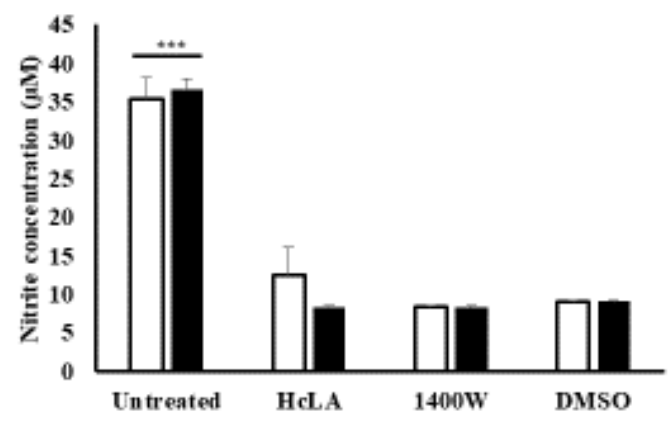

B.

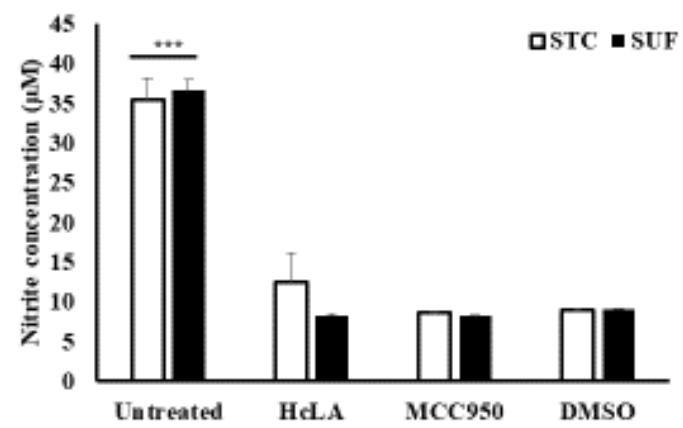

Figure 3.6: Measure of nitrite in cellular supernatant

PBMC derived from St. Croix (STC) and Suffolk (SUF) sheep were isolated from whole blood and cultured with CM (untreated) or $20 \mu \mathrm{g} / \mathrm{ml}$ of HcLA, $0.3 \%$ DMSO, $100 \mathrm{~nm}$ MCC950, or 10 $\mu \mathrm{g} / \mathrm{ml} \mathrm{1400W}$. A) HcLA culture, B) culture with HcLA and $100 \mathrm{~nm}$ MCC950, C) addition of $1400 \mathrm{~W}$ to culture. Following culture supernatant was collected nitrite concentrations were measured. Each treatment was performed in triplicate. Error bars represent SEM. Significance was accepted at $\mathrm{P}<0.05$. *** $\mathrm{P}<0.001$. 
Table 3.1: qPCR primers for SYBR Green chemistry

\begin{tabular}{|c|c|c|c|}
\hline Gene Name & Abbreviation & Primer & Accession \# \\
\hline Glyceraldehyde3-phosphate & GAPDH & $\begin{array}{l}\text { F- CAGGAGCACGAGAGGAAGAG } \\
\text { R- AATGTATGGAGGTCGGGAGA }\end{array}$ & HM043737 \\
\hline $\mathrm{T}$ box transcription factor & TBET & $\begin{array}{l}\text { F- TACTACCGAAGCCAGGAAGC } \\
\text { R- AGAGTTCGCATGGAGTGGAA }\end{array}$ & \\
\hline Interferon- $\gamma$ & IFN $\gamma$ & $\begin{array}{l}\text { F- ATGACGTGTCGCCAAAATC } \\
\text { R- GCAGGCAGGAGAACCATTAC }\end{array}$ & NM_001123004.1 \\
\hline GATA binding protein 3 & GATA3 & $\begin{array}{l}\text { F- TCATCAAGCCCAAGCGAAGG } \\
\text { R- TGGCATTTCTTCTCCACAGAGT }\end{array}$ & \\
\hline $\begin{array}{l}\text { Signal transducer and } \\
\text { activator of transcription } 6\end{array}$ & STAT6 & $\begin{array}{l}\text { F-GCGTGTGAGTGTGTGTCCT } \\
\text { R-ACACTCCCTCCCACATACACA }\end{array}$ & \\
\hline $\begin{array}{l}\text { Signal transducer and } \\
\text { activator of transcription } 3\end{array}$ & STAT3 & $\begin{array}{l}\text { F- CCTCCCTGATTGTGACCGAG } \\
\text { R- CAATGAGTGCGTCTCCAGGT }\end{array}$ & \\
\hline Forkhead box P3 & FOXP3 & $\begin{array}{l}\text { F- GAAACAGCACATTCCCAGAGT } \\
\text { R- GGATGAGGGTGGCATAGGT }\end{array}$ & \\
\hline Interleukin-10 & IL-10 & $\begin{array}{l}\text { F- TTTCCCTGACTGCCCTCTAA } \\
\text { R- GCTCCCTGGTTTCTCTTCCT }\end{array}$ & \\
\hline Toll-like receptor 2 & TLR2 & $\begin{array}{l}\text { F- CTCTTCCTGTTGCTCCTGCT } \\
\text { R- CTTCCTGGGCTTCCTCTTG }\end{array}$ & GQ221063.1 \\
\hline Toll-like receptor 4 & TLR4 & $\begin{array}{l}\text { F- GGCATCATCTTCATCGTCCT } \\
\text { R- CCACTCCAGGTAGGTGTTCC }\end{array}$ & НМ099914.1 \\
\hline Interleukin-1 $\beta$ & IL-1 $\beta$ & $\begin{array}{l}\text { F- GAAGGGAAGGGAAGAACACC } \\
\text { R- ACGAATACAGGGGAGGCAGT }\end{array}$ & NM_001009251.1 \\
\hline
\end{tabular}




\section{Chapter 4: Exploratory Discussion}

The purpose of experiments within this dissertation were to investigate the role of NLRP3 in both a classic model of infection and within an abnormal Th2 parasitic infection. Literature has shown parasite resistant STC sheep mount an effective Th2 response, while SUF sheep struggle to respond as reported by delayed responses. From this, we hypothesized SUF sheep will mount an effective response to bacterial challenge. However, upon LPS stimulation of PBMC, STC PBMC were the only breed able to activate TLR4 downstream signaling events following 3 hours of stimulation. We focused on 3 hours, due to a curiosity of breed differences observed in early responses. Within STC PBMC we have seen an upregulation in IL-1 $\beta$ production, promoting inflammatory responses.

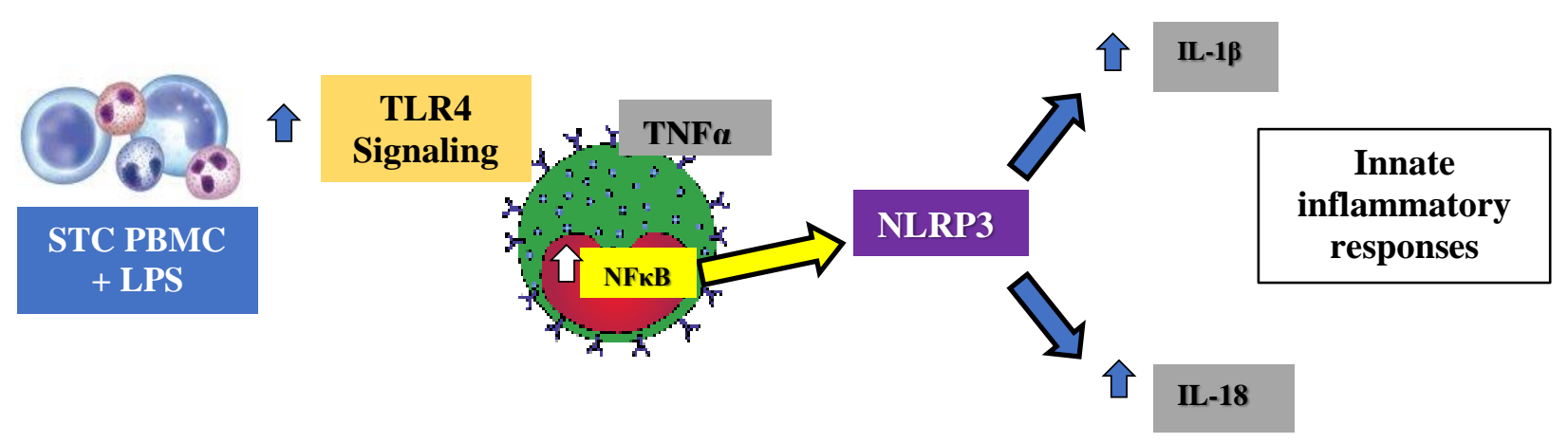

Figure 4.1: Model for STC PBMC responses to LPS stimulation STC PBMC upon stimulation with LPS result in early activation of TLR4 signaling. The addition of LPS to culture upregulates TLR4 found on classically activated (M1) macrophages. LPS binds TLR4 and activates downstream signaling events, resulting in the upregulation of the proinflammatory transcription factor NFKB. TLR4 priming is the first signal in NLRP3 activation. The upregulation of NFKB and proinflammatory responses will lead to the activation of NLRP3. NLRP3 inflammasome activation will result in the enhanced production of both IL-1 $\beta$ and IL-18. Leading to an early innate local inflammatory response necessary for pathogen clearance. The inhibition of NLRP3 in STC PBMC results in a reduction in TLR4 signaling, which in turn reduces the likelihood of the localized inflammatory response necessary for pathogen clearance. 
Further investigation is necessary to uncover specific proteins critical for early STC immune responses. Inhibition assays of proteins found both upstream and downstream NLRP3 protein are necessary to ensure that STC responses are NLRP3 dependent. Our data show that the inhibition of NLRP3 results in ablation of STC responses following LPS stimulation. Assays investigating the consequences of the inhibition of proteins such as, TLR4, IRF3, and IRAK3 to name a few.

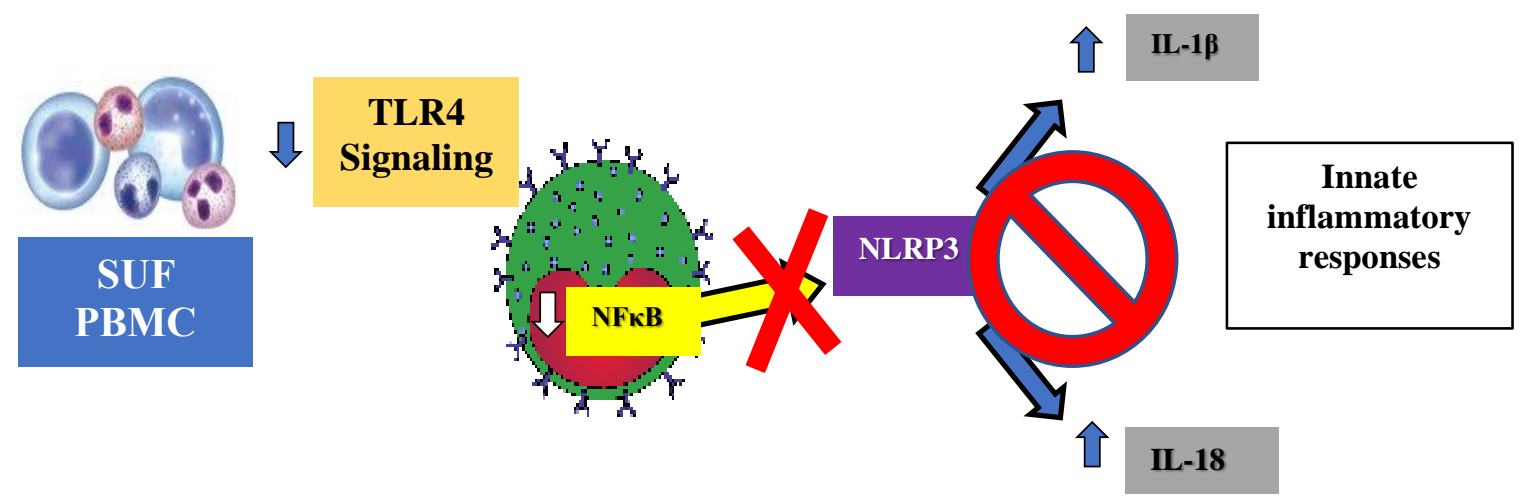

\section{Figure 4.2: Model for SUF PBMC responses to LPS stimulation}

The stimulation of SUF PBMC with LPS results in the downregulation of TLR4 expression. SUF PBMC are unable to respond to LPS challenge in a classic TLR4 signaling pathway, there is something inhibiting the process. Downregulation of TLR4 expression results in the downregulation of NFKB transcription factor which will in turn result in the inhibition of NLRP3 activation and lead to diminished localized inflammatory responses. We have reason to believe that SUF have a dysfunctional NLRP3 protein. In this classic model of infection in which we would expect SUF PBMC to be able to respond to LPS challenge, they are unable to do so. SUF have a defective NLRP3 protein inhibiting their ability to elicit early immune responses to bacterial pathogens. Further investigation of the signal events both upstream and downstream of NLRP3 are necessary to pinpoint the role of specific proteins. 
The downregulation observed in TLR4 expression on SUF PBMC leads me to believe that SUF delays could be a result of lack of antigen recognition. The use of TLR4 inhibitors and performing both gene expression and ELISA analysis to observe inflammatory responses are necessary. These data continue to highlight differences observed in immune responses between STC and SUF sheep. NLRP3 has been shown to enhance Th2 responses by the production of IL18 upregulating the expression of Th2 transcription factor GATA3. This begs the question of NLRP3's role in Haemonchus contortus infection in sheep? Could NLRP3 be acting as a transcriptional regulator for Th2 responses?
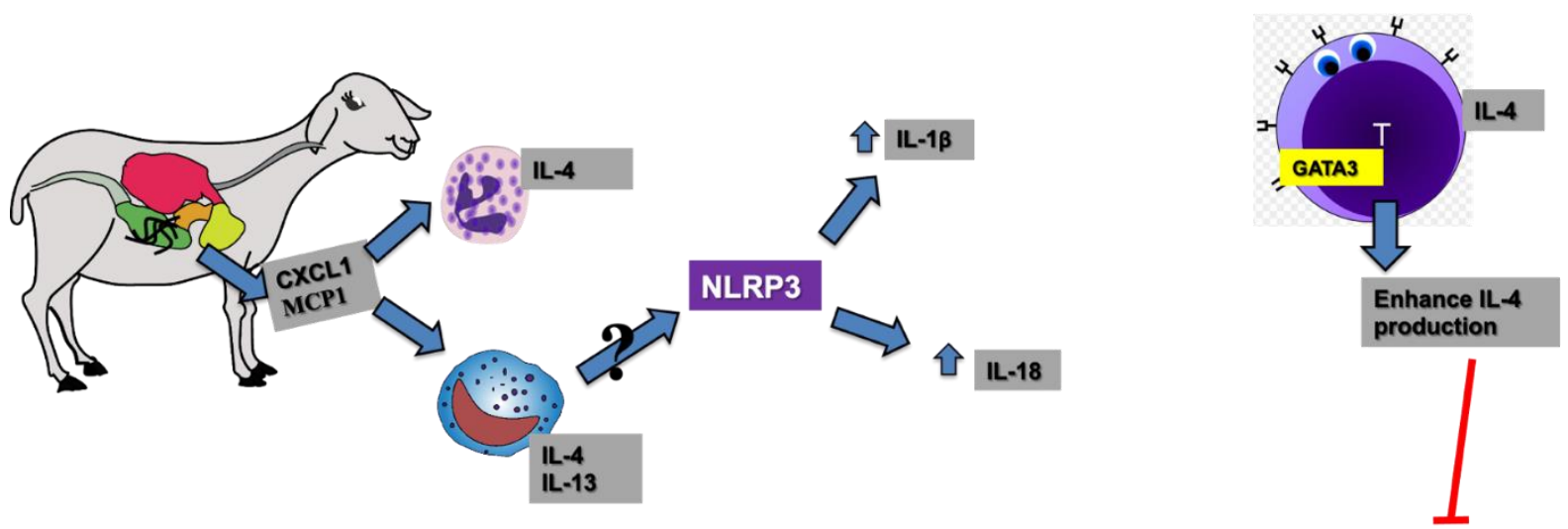

Parasite establishment

\section{Figure 4.3: Model for NLRP3 in Haemonchus contortus infection in sheep}

Sheep are burdened with parasites in the abomasum, epithelial cells and innate lymphoid cells will respond by secreting chemokines such as, CXCL1 and MCP1 to induce both neutrophil and macrophage recruitment to the site of infection. Neutrophils will produce IL-4 in response to parasite challenge, the enhanced IL-4 environment will result in alternative activation of macrophages (M2). Macrophages will respond by producing IL-4 and IL-13 to assist in the autocrine activity of immune activation. NLRP3 inflammasome is activated in macrophages (these preliminary data are not enough to say for sure, which mode of activation) which will result in the production of mature IL-1 $\beta$ and IL-18. The production of IL-18 will result in the upregulation of the Th2 transcription factor GATA3 in T cells, which will in turn enhance the production of IL-4 in $\mathrm{CD}^{+}$cells. Leading to a robust $\mathrm{Th} 2$ immune response ensuing the inhibition of parasite establishment. Within this model products of NLRP3 inflammasome activation act as a transcriptional regulator for Th2 responses. 
These models highlight the need for further investigation into the role of NLRP3 in $H$. contortus parasitic infection. Without knowing the protein make up of HcLA, this makes it difficult to identify specific modes of cellular activation. However, based off of data from this dissertation we are able to identify a role for NLRP3 in STC responses to both a classic LPS model of infection and an abnormal parasite infection model. The inhibition of NLRP3 in STC resulted in a significant reduction in responses. Next steps in this research should include to design primers and perform DNA sequencing to validate differences in NLRP3 primary protein sequence. To validate differences in protein structure, perform a non-denaturing western to validate the results of the predicted protein software by comparing the NLRP3 protein size between both breeds. Running a western to observe inactive and active forms of NLRP3 would aid in identifying differences in NLRP3 protein. There is a chance that due to NLRP3 structural differences observed the pharmacological inhibitor MCC950 could be interacting differently between the breeds, there could be inappropriate binding within SUF PBMC. Performing a western on inhibitor treated groups will help to ensure NLRP3 inflammasome is not intact. Alignment of both TLR4 and NLRP3 sequences from STC and SUF sheep can be aligned to known reference genomes available of NCBI to observe single nucleotide polymorphisms (SNPs) between breeds. Incorporating more sheep breeds into the experiments will help to identify if this dysfunctional NLRP3 protein is breed specific or is it representative of all parasite-susceptible breeds of sheep? 